
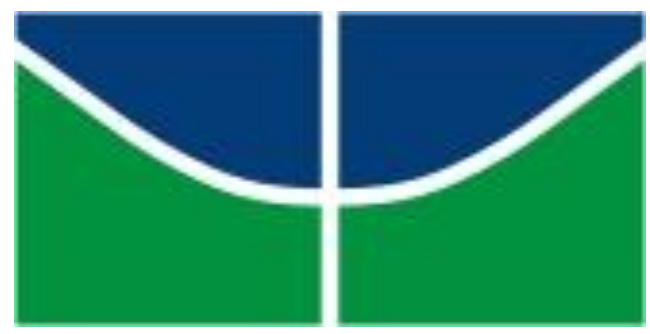

UNIVERSIDADE DE BRASÍLIA

INSTITUTO DE CIÊNCIAS BIOLÓGICAS

PROGRAMA DE PÓS-GRADUAÇÃO EM BOTÂNICA

\title{
Ecologia e funções adaptativas da dormência em sementes de gramíneas campestres brasileiras
}

DESIRÉE MARQUES RAMOS

BRASÍLIA

Distrito Federal - Brasil

Outubro/2015 
UNIVERSIDADE DE BRASÍLIA

INSTITUTO DE CIÊNCIAS BIOLÓGICAS

DEPARTAMENTO DE BOTÂNICA

PROGRAMA DE PÓS-GRADUAÇÃO EM BOTÂNICA
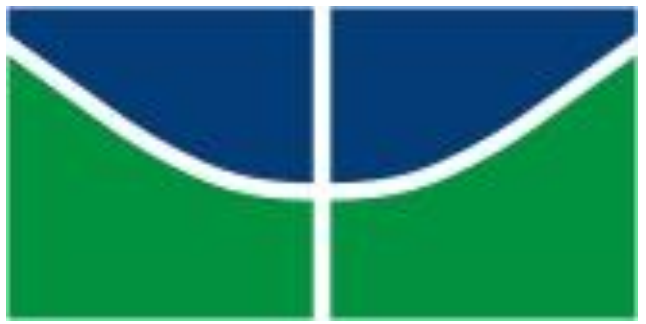

\section{Ecologia e funções adaptativas da dormência em sementes de gramíneas campestres brasileiras}

Desirée Marques Ramos

Orientador: Dr. José Francisco Montenegro Valls

BRASÍLIA

Distrito Federal - Brasil

Outubro/2015 


\section{UNIVERSIDADE DE BRASÍLIA}

INSTITUTO DE CIÊNCIAS BIOLÓGICAS

DEPARTAMENTO DE BOTÂNICA

PROGRAMA DE PÓS-GRADUAÇÃO EM BOTÂNICA

\section{Ecologia e funções adaptativas da dormência em sementes de gramíneas campestres brasileiras}

Desirée Marques Ramos

Tese apresentada ao Programa de Pós-graduação em

Botânica do Departamento de Botânica - IB da

Universidade de Brasília, como parte dos requisitos necessários para obtenção do título de Doutora em Botânica sob a orientação do Prof. Dr. José Francisco Montenegro Valls.

BRASÍLIA

Distrito Federal - Brasil

Outubro/2015 


\section{AGRADECIMENTOS}

Agradeço aos meus pais, Daniel Ramos de Oliveira e Zuleica do Carmo Marques Ramos, que nunca hesitaram em oferecer o melhor que tinham aos filhos e apoiá-los, mesmo que isto significasse abrir mão de sonhos e objetivos pessoais. Agradeço aos meus irmãos Yuri, Renan, Thales e Stella com os quais aprendi que dividir não significa diminuir. Agradeço também, ao meu sogro Benedito e sogra Marielene, os quais considero como meus pais. Agradeço, especialmente, as minhas tias Lêda, Zilene, Dine

e Cleide e aos meus tios Saulo, Bóris, Marcus e Wellington cujo apoio e incentivo foram essenciais nessa jornada.

Agradeço ao marido, biólogo, amigo e parceiro, Pedro Diniz. Muito obrigada por aceitar dividir comigo os sonhos e por sempre me motivar. Os conflitos existem, mas nos momentos mais difíceis você esteve ao meu lado e me mostrou o valor da cooperação!

Agradeço ao mestre e orientador José Francisco Montenegro Valls que, mesmo após sete anos de convívio, continua a me surpreender. Sua dedicação, seriedade e paixão pela pesquisa continuam a me comover e inspirar. Quem me dera, um dia, ser igual a você!

Agradeço, imensamente, ao professor e também orientador Fabian Borghetti, que me recebeu de braços abertos em seu laboratório. Sem a paciência e constante ajuda deste pesquisador este trabalho não teria sido a metade do que é.

Agradeço aos estagiários que trabalharam comigo, Vanessa Fujiyama, Guilherme Marques, Ana Liaffa e Fernanda Silva (meu braço direito!). Muito obrigada pelo prazeroso convívio durante os dias de trabalho. Foi muito bom poder contar com vocês!

Agradeço a grande família do Laboratório de Termobiologia, Odete (nossa mãe), Francisco, Manoel, Antônio, Daniel, Graziela, Bruno, Eduardo, Rafael, Leandro, Patrícia, 
Juli. Agradeço, especialmente, a Anabele Gomes, amiga e técnica admirável! Pessoal, vocês tornaram o trabalho mais leve, foi um prazer conviver com vocês!

Agradeço as minhas irmãs/irmão de orientação João, Suzi, Daniele, Adriana, Andressa e Rafaella. Foi muito bom compartilhar esta experiência com vocês!

Agradeço ao amigo Vandélio (Vando), que sempre foi a campo comigo e cujo bom humor e boa prosa tornaram o trabalho mais prazeroso até nos momentos mais difíceis!

Agradeço aos membros desta e das bancas passadas: Sarah Caldas, Dulce Silva, Isabel Schmidt, Augusto Franco, Eduardo Barbosa e Arnildo Pott. O criticismo destes pesquisadores, sem dúvidas, foi fundamental para melhorar a qualidade deste trabalho.

Agradeço a Capes e a Embrapa, que por meio do projeto CAPES-EMBRAPA concederam-me a bolsa de doutorado e estágio no exterior. Agradeço a Universidade de Brasília e professores do Programa de Pós-graduação em Botânica (especialmente a Cássia Munhoz), instituição na qual realizei as pesquisas e que teve um importante papel na minha formação acadêmica.

A todos vocês MUITO OBRIGADA 


\section{SUMÁRIO}

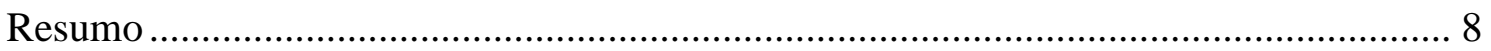

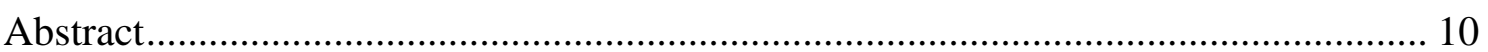

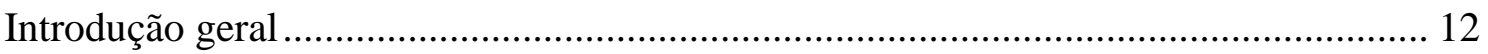

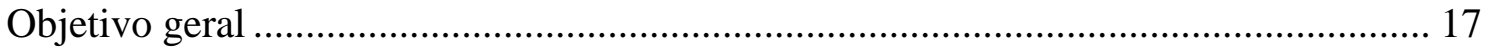

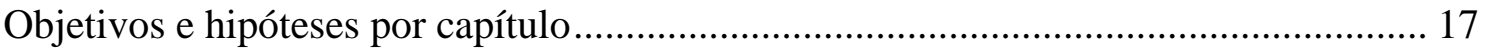

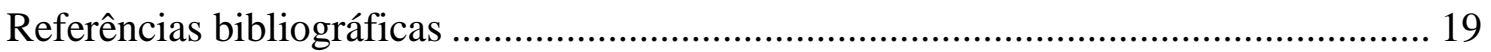

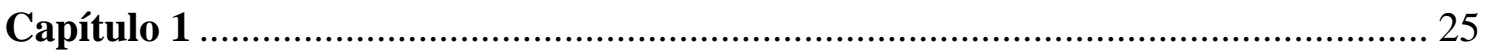

Avoiding the dry season: dispersal time and syndrome mediate seed dormancy in

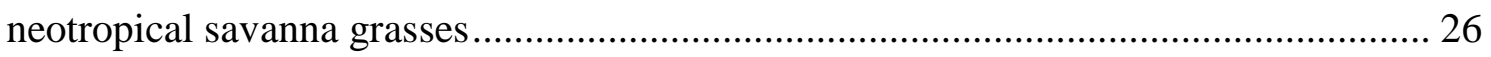

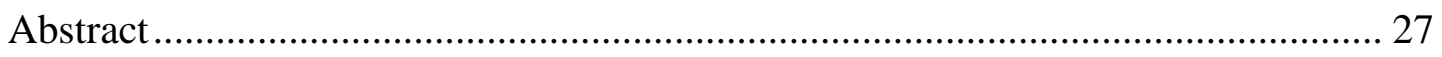

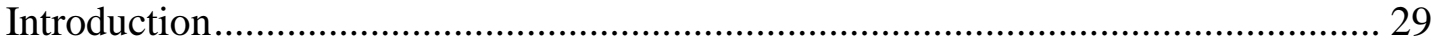

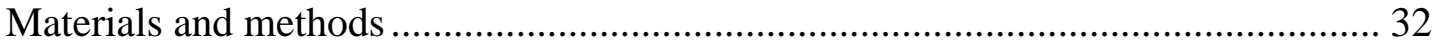

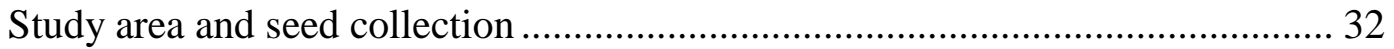

Dispersal syndrome and seed dispersal time..................................................... 34

Dormancy level of freshly harvested and stored seeds .................................. 34

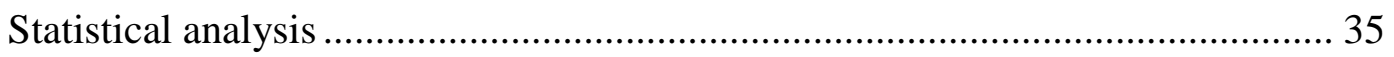

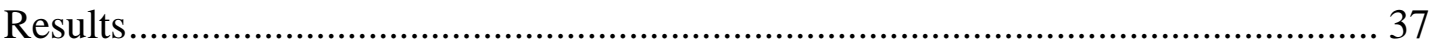

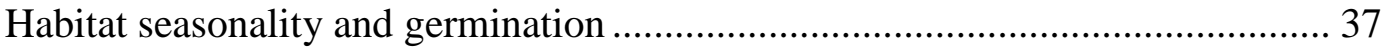

Dormancy level comparison against dispersal time and dispersal syndrome ....... 37

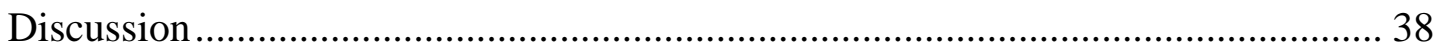

Seed dormancy at the end of the rainy season may avoid risky germination ....... 39

Trade-off between seed dispersal and level of dormancy ................................ 40

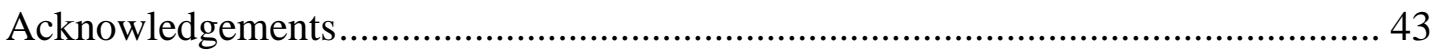

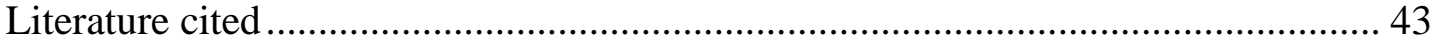

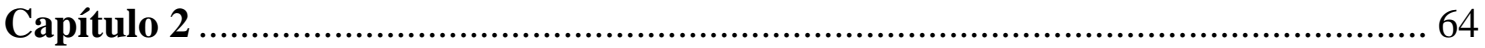

Seed tolerance to heating is better predicted by seed dormancy than by habitat type in

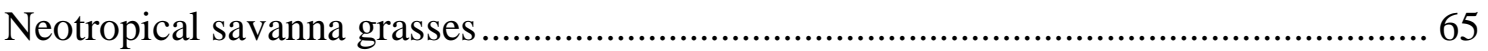

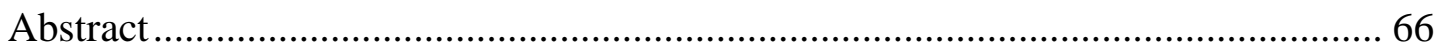

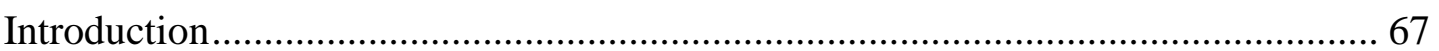

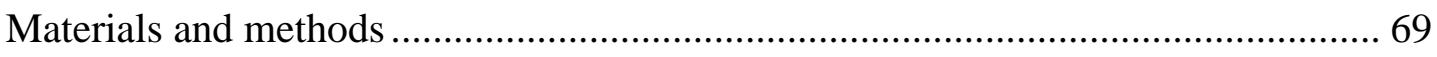

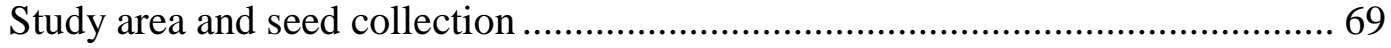

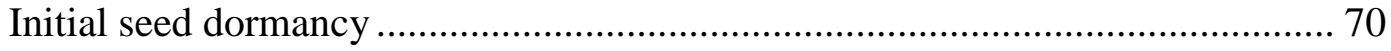




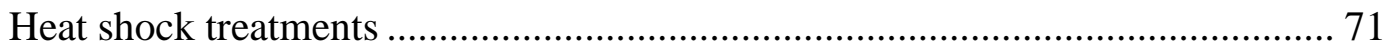

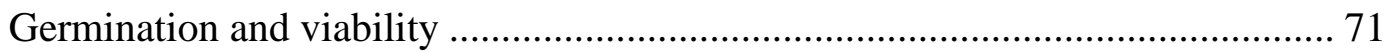

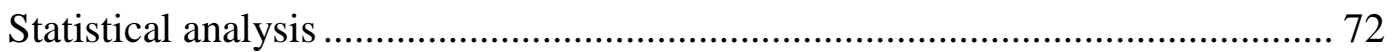

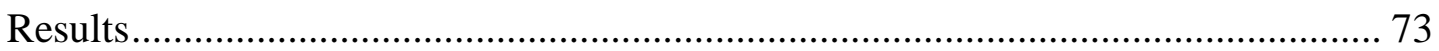

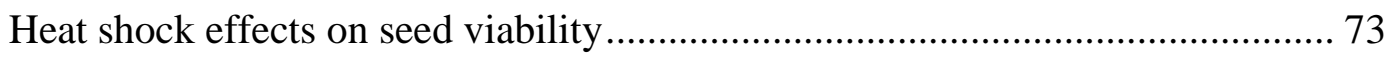

Effects of dormancy status and habitat on seed viability after heat shock............ 73

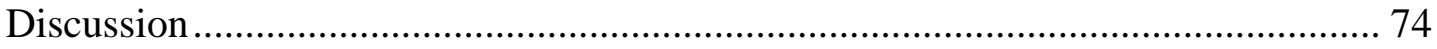

Dormancy and habitat effects on seed tolerance to heating ................................ 75

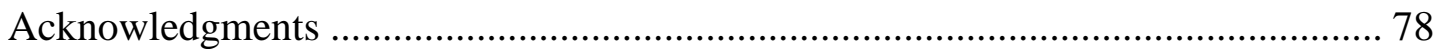

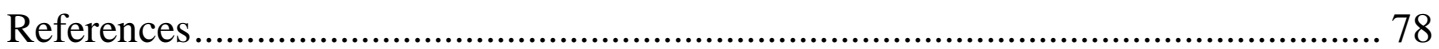

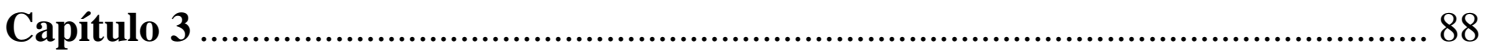

Temporal changes in seed dormancy, germination and viability of grasses from

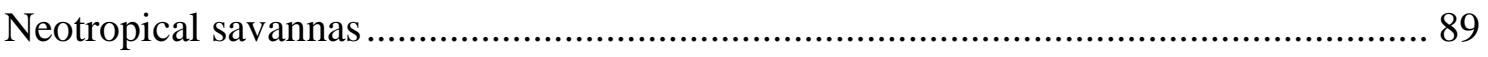

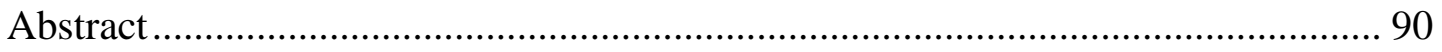

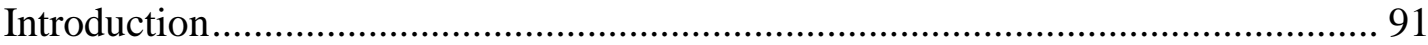

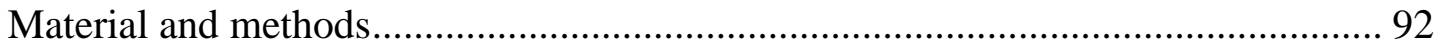

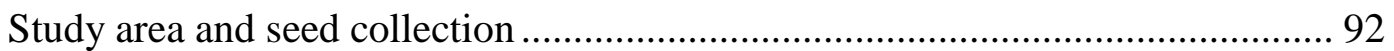

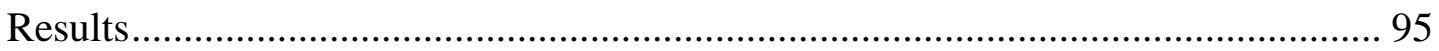

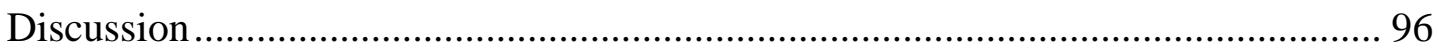

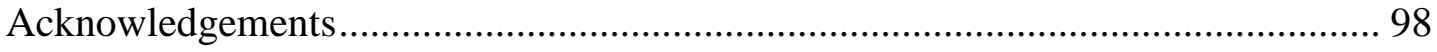

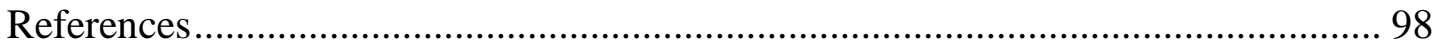

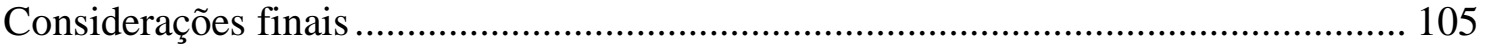




\section{RESUMO}

O Cerrado, a savana brasileira, caracteriza-se por um clima com precipitação sazonal e com recorrente passagem de fogo. Em teoria, o número de espécies com sementes dormentes tende a ser maior em ambientes com sazonalidade hídrica do que em ambientes não-sazonais, porque a estação seca constitui um forte limitante ao recrutamento de plântulas. No entanto, apesar da reprodução das gramíneas nativas no Cerrado ser limitada pela sazonalidade, existe ampla variação entre espécies na presença e duração da dormência. As causas desta variação, bem como suas consequências ecológicas, permanecem desconhecidas. Assim, o objetivo deste estudo foi determinar os padrões de longevidade, germinação e dormência (i.e. estratégia de germinação) de sementes de 29 espécies de gramíneas nativas do Cerrado, investigando possíveis causas evolutivas e consequências ecológicas dessas estratégias, além da potencial aplicabilidade das sementes dessas espécies em restauração ecológica. No capítulo 1, investiguei duas hipóteses para a evolução de dormência: (1) restrição hídrica e (2) competição intraespecífica durante o recrutamento de plântulas. Assumindo que a dispersão limitada resulta em adensamento de sementes e, consequentemente, maior competição durante o desenvolvimento das plântulas, comparei as estratégias de germinação de espécies de habitats que diferem em umidade do solo (campo sujo vs. campo úmido) e épocas de dispersão contrastantes em termos de sazonalidade hídrica (início ou fim da estação chuvosa e estação seca), e diferentes síndromes de dispersão (anemocórica vs. barocórica). Sementes de campos úmidos perderam a dormência mais rapidamente e permaneceram vivas por mais tempo do que sementes de campos sujos. Sementes dispersas na seca e no início da estação chuvosa tiveram maior germinação do que sementes dispersas no final da estação chuvosa. Sementes com dispersão barocórica foram mais dormentes do que sementes com dispersão anemocórica. No capítulo 2, verifiquei se a a probabilidade de uma semente passar por um evento de queima e se as 
diferenças de temperaturas que ocorrem durante a passagem do fogo nos habitats das espécies de gramíneas determinam a tolerância das sementes a altas temperaturas. Assumindo que sementes dormentes passam mais tempo no solo do que sementes não dormentes e, portanto, estão mais susceptíveis a passar por um evento de queima, comparamos a tolerância a choques-térmicos $\left(80^{\circ} \mathrm{C}\right.$ e $\left.110^{\circ} \mathrm{C}\right)$ em sementes dormentes e não dormentes. Também testamos a tolerância a choques-térmicos em sementes de espécies coletadas em habitats com menores temperaturas do fogo (campo úmido) e maiores temperaturas do fogo durante a queima (campo sujo). Sementes de ambos os habitats foram negativamente afetadas por altas temperaturas. Entretanto, sementes dormentes foram mais tolerantes a altas temperaturas do que sementes não dormentes. Por fim, no capítulo 3, verificamos as variações temporais nos padrões de longevidade e germinação de 29 espécies de gramíneas, e identificamos 20 espécies com potencial para utilização na recuperação de áreas degradadas. Em conclusão, nossos resultados sugerem que (1) a dormência em sementes de gramíneas do Cerrado evoluiu em resposta à restrição hídrica e à competição intraespecífica; (2) e a tolerância ao fogo é possivelmente uma consequência ecológica da dormência.

Palavras-chave: Cerrado, germinação, Poaceae, longevidade, sazonalidade, síndrome de dispersão, fogo. 


\section{ABSTRACT}

Cerrado, the Brazilian savanna, is characterized by a climate with seasonal precipitation and frequent fire events. In theory, the number of species with seed dormancy is higher in seasonal environments compared to species in non-seasonal environments, due to the fact that dry seasons may strongly limit seedling recruitment. However, although reproduction of grass species in the Cerrado is limited by seasonality, there is a high variation in the presence of seed dormancy and its duration among these species. The origin and the ecological consequences of this variation remain unknown. Therefore, the aim of this study was to determine the longevity, germination, and dormancy patterns (i.e. germination strategies) of seeds from 29 native grass species from the Cerrado. This study also aimed to investigate the possible evolutionary causes and ecological consequences of these strategies, as well as the potential applicability of these species in restoration ecology. In chapter 1, we investigated two hypotheses for seed evolution: (1) water restriction and (2) intraspecific competition during seedling recruitment. We assumed that limited dispersion results in seed crowding and, consequently, higher competition during seedling growth. Thus, comparisons were conducted regarding the germination strategies of species from contrasting habitats (open savanna vs. wet grassland), seed dispersal season in terms of water availability, and different dispersal syndromes (anemochoric vs. barochoric). Seeds from wet grassland species lost dormancy faster and were viable for longer periods than seeds from open savanna species. Seeds dispersed during the dry season or early in the rainy season germinated more than those dispersed late in the rainy season. Species with barochoric seeds had more seed dormancy than species with anemochoric seeds. In chapter 2 , the aim was to verify if the likelihood of a seed to burn and the differences in temperature that occur during fires in species' habitats may determine seed tolerance to heat. Assuming that dormant seeds 
might remain in the soil longer than non-dormant seeds, increasing their likelihood to burn, the heat tolerance $\left(80\right.$ and $\left.110{ }^{\circ} \mathrm{C}\right)$ of species with dormant and non-dormant seeds was compared. In addition, the heat tolerance of seeds from species from habitats with lower (wet grasslands) and higher (open savannas) fire temperatures was also tested. Seeds from both habitats were negatively affected by high temperatures, but dormant seeds had a higher tolerance than non-dormant seeds. Finally, in chapter 3, the variation in temporal patterns of seed longevity and germination in 29 grass species were verified, and 20 species with ecological restoration potential were identified. In conclusion, the results suggest that (1) seed dormancy in grass seeds from the Cerrado evolved in response to water restriction and intraspecific competition; (2) and seed tolerance to fire is probably an ecological consequence of seed dormancy.

Key words: Cerrado, seed germination, Poaceae, seed longevity, seasonality, dispersal syndrome, fire. 


\section{INTRODUÇÃO GERAL}

\section{Sazonalidade da precipitação e dormência}

A dormência pode ser caracterizada pela não germinação de uma semente em condições adequadas (i.e. água, temperatura, oxigênio) para que a germinação ocorra. A dormência em sementes pode ser vista como uma resposta adaptativa a condições de estresse, muitas destas associadas à sazonalidade, como por exemplo, o dessecamento do solo durante a estação seca (Garwood 1983; Mathias \& Kisdi 2002). Uma das consequências da dormência é a distribuição da germinação no tempo em dada população de sementes (Bewley 1997). Esta característica proporciona maior aptidão a plantas de ambientes sazonais, pois reduz a probabilidade de germinação em época não favorável para o estabelecimento da plântula (Keya 1997). Tendo isso em conta, o número de espécies com sementes dormentes encontrada é maior em ambientes com algum nível de sazonalidade na precipitação ou temperatura ( 80\%) do que ( 40\%) em ambientes não sazonais, ou seja, com ausência de uma estação seca e/ou fria (Jurado \& Flores 2005).

O Cerrado é composto por um mosaico de fisionomias de savanas, florestas e campos na região central do Brasil. O clima é marcadamente sazonal, com um inverno seco de abril a setembro e um verão chuvoso de outubro a março (precipitação média entre $800-2000 \mathrm{~mm}$ ), com temperatura média de $18^{\circ} \mathrm{C}$ e $28^{\circ} \mathrm{C}$, respectivamente (Oliveira-Filho \& Ratter 2002). Com cerca de 600 espécies a família Poaceae tem alta representatividade no Cerrado (Filgueiras et al. 2014). Além disso, é uma família com alta abundância e frequência em áreas campestres do Cerrado. Por possuírem sistema radicular não profundo, a absorção de água em gramíneas está limitada às camadas superficiais do solo (5-50cm; ver Rossatto et al. 2013) e, consequentemente, são afetadas pela escassez de água durante a seca. Assim, a floração e frutificação é restrita, principalmente, à estação chuvosa (Tannus et al. 2006; Munhoz \& Felfili 2007; Ramos et 
al. 2014). Porém, a dispersão das sementes ocorre principalmentes durante a estação chuvosa com algumas espécies dispersando também durante a seca (Silva \& Ataroff 1985; Almeida 1995). Em teoria, sementes dispersas no início da chuva, entre outubro e janeiro, tem toda a estação chuvosa para germinar e estabelecimento das plântulas (cerca de sete meses). Por outro lado, a germinação nos últimos meses de chuva, entre fevereiro e abril, pode ser arriscada e o estabelecimento das plântulas prejudicado, devido ao curto período que resta de estação chuvosa (menos de quatro meses). Além disso, o solo pode estar úmido no início da estação seca devido as últimas chuvas da estação chuvosa. Assim, a germinação de sementes dispersas na estação seca, entre maio e setembro, pode ser prejudicial para o estabelecimento das plântulas devido ao dessecamento do solo nos meses seguintes. Diante disto, pode-se esperar a existência de um maior número de espécies com dormência entre as espécies que dispersam no final da estação chuvosa e na seca em comparação as espécies que dispersam no início da estação chuvosa.

Além da sazonalidade climática da região existe uma variação na sazonalidade hídrica relacionada a umidade do solo em fisionomias campestres do Cerrado. Nos campos sujos, que possuem lençol freático profundo, as camadas superficiais do solo secam durante a estação seca. Por outro lado, nos campos úmidos as camadas superficiais do solo permanecem úmidas por um determinado tempo dentro da estação seca, uma vez que o lençol freático se encontra mais próximo a superfície. A sazonalidade hídrica é menos marcante em campos úmidos do que em campos sujos e, por esse motivo, esperase que as sementes de espécies de gramíneas coletadas em campos úmidos tenham menor dormência do que sementes de espécies coletadas em campos sujos.

\section{Trade-off entre estratégia de dispersão e dormência}

Além da função de evitar períodos de seca em ambientes com sazonalidade hídrica, outra explicação alternativa existente é de que a dormência pode ter evoluído em 
resposta, à competição por recursos entre organismos da mesma espécie, incluindo parentes (e.g. planta-mãe ou irmãos; hipótese da competição com parentes - Howe \& Smallwood 1982; Kobayashi \& Yamamura 2000; Cheplick 1992). A existência de alguma modalidade de dormência que espalhasse germinação das sementes ao longo do tempo a poderia contribuir com a redução da competição direta intraespecífica. Neste contexto, a estratégia de dispersão poderia ser um fator de relevante influência na evolução da dormência em sementes (Rees 1993, 1994; Baskin \& Baskin 2014). Por exemplo, espécies que apresentam sistemas de dispersão que possibilitam maior distância de dispersão, como o anemocórico, teriam em consequência menor pressão de competição por recursos entre as plântulas de determinada progênie e entre estas e a planta-mãe (Venable \& Brown 1988; Cheplick 1993). Assim, em teoria, espécies que apresentam maior distância de dispersão das sementes teriam menor pressão seletiva no estabelecimento da dormência (Lu et al. 2010), de maneira que os propágulos de espécies que fossem dispersos a grandes distâncias apresentariam menor grau de dormência do que propágulos de espécies dispersos demasiadamente próximos a planta-mãe (Fenner \& Thompson 2005). Além disto, espécies com sementes sem dormência evitariam os custos associados à dormência, como o maior tempo de exposição à predação e a patógenos, assim como a evolução de mecanismos de defesa como compostos secundários (Thompson 1987).

A maior parte das espécies de gramíneas possui fruto seco, chamado cariopse, que não se separa da semente (Filgueiras 1986). Este fruto, na maioria das vezes, é disperso com brácteas e apêndices, que tornam estes diásporos complexos (a partir daqui será referido como semente). As sementes das gramíneas apresentam considerável variação quanto à síndrome de dispersão (Peart 1979, 1981, 1984; Silberbauer-Gottsberger 1984; Ernst et al. 1992; Guerrero \& Tye 2009), dentre as quais destacam-se a dispersão pelo 
vento, anemocoria (Andropogon L.), por gravidade, barocoria (algumas espécies de Paspalum L. e Panicum L.) e ingestão por animais, endozoocoria (Lasiacis (Griseb.) Hitchc.) (Davidse \& Morton 1973). Algumas espécies, como Echinolaena inflexa (Zuloaga \& Morrone 2003), de dispersão primária barocórica possuem elaiossomos (Davidse 1986), estruturas que atraem as formigas, que podem possibilitar a dispersão secundária (van der Pijl 1982). A endozoocoria e a anemocoria têm sido reconhecidas como eficientes mecanismos de dispersão a longas distâncias (Ernst et al. 1992; Couvreur et al. 2004a; Couvreur et al. 2004b). Estruturas como tricomas longos podem facilitar a dispersão dos diásporos de gramíneas de savanas pelo vento (Chase \& Sendulsky 1991). Desta forma, estes diásporos podem atingir maiores distâncias de dispersão. Por outro lado, espécies que possuem estratégia de dispersão barocórica dispersam suas sementes próximas à planta mãe e, a menos que essas espécies possuam dispersão secundária, a germinação de suas sementes teoricamente poderá resultar em competição por recursos entre as plântulas e estas com a planta mãe, em caso de plantas perenes (Howe \& Smallwood 1982; Kobayashi \& Yamamura 2000; Cheplick 1992).

\section{Efeitos do fogo na sobrevivência e germinação de sementes em savanas}

As queimadas recorrentes são características das savanas e o estrato herbáceo é o principal combustível para o fogo (Kauffman et al. 1994; Mistry 1998; Hoffmann et al. 2012). Durante a passagem do fogo as sementes ficam expostas fatores como altas temperaturas e fumaça, que podem ter efeitos na germinação e sobrevivência das mesmas (Gashaw \& Michelsen 2002; Clarke \& French 2005; Dayamba et al. 2008; Scott et al. 2010). Estudos sugerem que a frequência do fogo e as altas temperaturas geradas durante as queimadas influenciam os padrões de sobrevivência em sementes (Ribeiro et al. 2012; Ribeiro \& Borghetti 2013). A sobrevivência das sementes a altas temperaturas é considerada uma adaptação ao fogo em espécies de plantas de ambientes propensos a 
queimadas (Gashaw \& Michelsen 2002; Clarke \& French 2005; Overbeck et al. 2006; Dayamba et al. 2008; Scott et al. 2010). Assim, sementes de espécies de habitats que queimam frequentemente (cerrado típico) são mais tolerantes a altas temperaturas do que sementes de espécies de habitats com menor frequência ou ausência de queimadas (matas de galeria) (Ribeiro et al. 2012; Ribeiro \& Borghetti 2013).

No Cerrado, o comportamento do fogo difere entre fisionomias de campo sujo e campo úmido (Miranda et al. 2009; Schmidt 2011). A intensidade do fogo é menor em campos úmidos (1083 $\left.\mathrm{kJ} \mathrm{s}^{-1} \mathrm{~m}^{-1}\right)$ do que em campos sujos (20393 $\left.\mathrm{kJ} \mathrm{s}^{-1} \mathrm{~m}^{-1}\right)$, provavelmente devido a maior umidade do combustível nos campos úmidos (Miranda et al. 2009; Schmidt 2011). Outro fator importante é que as temperaturas máximas do ar (1 cm acima do nível do solo) que ocorrem durante a passagem do fogo são maiores em campos sujos do que em campos úmidos. Além disto, o tempo de residência de temperaturas acima de $60{ }^{\circ} \mathrm{C}$ é menor em campos úmidos do que em campos sujos (Schmidt 2011). Assim, podemos esperar menor tolerância a choques térmicos com altas temperaturas em sementes de espécies de gramíneas de campos úmidos em relação a sementes de espécies de campos sujos.

Em savanas existe uma grande variação nos níveis de dormência em sementes de gramíneas (Baskin \& Baskin 1998; Baskin \& Baskin 2014). As sementes podem ser dormentes quando dispersam ou não ter dormência. Sementes dormentes, normalmente perdem a dormência após um certo tempo no solo, sincronizando a germinação com a estação chuvosa seguinte. Por outro lado, as sementes não dormentes podem germinar assim que dispersam, ficando menos tempo no solo. Por ficarem mais tempo no solo, as sementes dormentes aumentam a probabilidade de passar por um evento de queima do que sementes não dormentes. Diante disto, espera-se que sementes de espécies com 
dormência tenham maior tolerância a altas temperaturas do que sementes de espécies que não tenham dormência.

\section{OBJETIVO GERAL}

- Determinar os padrões de longevidade, estratégias de germinação e dormência de sementes de espécies de gramíneas nativas do Cerrado, investigando possíveis causas evolutivas e consequências ecológicas dessas estratégias, além da potencial aplicabilidade das sementes dessas espécies em restauração ecológica.

\section{OBJETIVOS E HIPÓTESES POR CAPÍTULO}

\section{Capítulo 1:}

Objetivo 1: Testar os efeitos da época de dispersão (estação seca, início e final da estação chuvosa) e do tipo de habitat da coleta das sementes (campos sujos e campos úmidos) na germinação e níveis de dormência de sementes de gramíneas nativas do Cerrado.

Hipóteses:

H1a) Sementes de espécies com dispersão no início da estação chuvosa são menos dormentes do que sementes de espécies com dispersão no final da estação chuvosa e na estação seca;

H1b) Sementes de espécies com dormência aumentam a germinação, ou seja, perdem a dormência, com o armazenamento;

H2a) Sementes de espécies coletadas em campos sujos (com maior restrição hídrica) são mais dormentes do que as sementes de espécies coletadas em campos úmidos (com menor restrição hídrica);

H2b) Sementes de espécies coletadas em campos úmidos tem menor duração de dormência do que sementes de espécies coletadas em campos sujos. 
Objetivo 2: Investigar a existência de um trade-off entre síndrome de dispersão (anemocórica ou barocóricas) e a presença de dormência em sementes de espécies de gramíneas nativas do Cerrado.

Hipóteses:

H1) Sementes de espécies com síndrome de dispersão barocórica tem maior dormência do que sementes de espécies com síndrome de dispersão anemocórica;

H2) Sementes de espécies com síndrome de dispersão barocórica perdem a dormência com o armazenamento.

\section{Capítulo 2:}

Objetivo 1: Verificar a tolerância de sementes de gramíneas a choques-térmicos com altas temperaturas, de espécies coletadas em habitats com diferentes temperaturas de fogo (campos sujos e campos úmidos);

Hipótese:

H) Sementes de espécies coletadas em campos sujos são mais tolerantes a altas temperaturas do que sementes de espécies coletadas em campos úmidos;

Objetivo 2: Verificar a tolerância de sementes de espécies de gramíneas com dormência e sem dormência a choques-térmicos com altas temperaturas.

Hipótese:

H) Sementes de espécies com dormência são mais tolerantes a altas temperaturas do que sementes de espécies sem dormência.

\section{Capítulo 3:}


Objetivo: Verificar os padrões temporais de longevidade e germinação de sementes de 29 espécies de gramíneas nativas do Cerrado com aplicabilidade na recuperação de áreas degradadas;

\section{REFERÊNCIAS BIBLIOGRÁFICAS}

Almeida SP. 1995. Grupos fenológicos da comunidade de gramíneas perenes de um campo Cerrado no Distrito Federal. Pesquisa Agropecuária Brasileira 30:1067-1073. Baskin CC, Baskin JM. 1998. Ecology of seed dormancy and germination in grasses. In: Cheplick GP. Population Biology of Grasses. Cambridge University Press.

Baskin CC, Baskin JM. 2014. Seeds: Ecology, Biogeography, and Evolution of Dormancy and Germination. Academic Press.

Bewley JD. 1997. Seed Germination and Dormancy. The Plant Cell 9: 1055-1066.

Chase A, Sendulsky T. 1991. Primeiro livro de gramíneas: Noções sobre a estrutura com exemplos da flora brasileira. São Paulo: Instituto de Botânica. [p.27-29].

Cheplick GP. 1992. Sibling competition in plants. Journal of Ecology 80: 567-75.

Cheplick GP. 1993. Sibling competition is a consequence of restricted dispersal in an annual cleistogamous Grass. Ecology 74(7): 2161-2164.

Clarke S, French K. 2005. Germination response to heat and smoke of 22 Poaceae species from grassy woodlands. Australian Journal of Botany 53: 445-454.

Couvreur M, Christiaen B, Verheyen K, Hermy M. 2004b. Large herbivores as mobile links between isolated nature reserves through adhesive seed dispersal. Applied Vegetation Science 7(2): 229-236.

Couvreur M, Vandenberghe B, Verheyen K, Hermy M. 2004a. An experimental assessment of seed adhesivity on animal furs. Seed Science Research 14: 147-159. 
Dayamba SD, Tigabu M, Sawadogo L, Oden P. 2008. Seed germination of herbaceous and woody species of the Sudanian savanna-woodland in response to heat shock and smoke. Forest Ecology and Management 256: 462-470.

Davidse G, Morton E. 1973. Bird-mediated fruit dispersal in the tropical grass genus Lasiacis (Gramineae: Paniceae). Biotropica 5(3): 162-167.

Davidse G. 1986. Fruit dispersal in the Poaceae. In: Soderstrom TR, Hilu KW, Campbell CS, Barkworth ME (Eds.). Grass Systematics and Evolution. International symposium. Smithsonian Institution Press, Washington, District of Columbia, pp. 143-155.

Ernst WHO, Veenendaal EM, Kebakile MM. 1992. Possibilities for dispersal in annual and perennial grasses in a savanna in Botswana. Vegetatio 102(1): 1-11.

Fenner M, Thompson K. 2005. The Ecology of Seeds. Cambridge University Press.

Filgueiras TS, Longhi-Wagner HM, Viana PL, Zanin A, Oliveira RC, Canto-Dorow TS, Shirasuna RT, Oliveira RP, Rodrigues RS, Santos-Gonçalves AP, Welker CAD, Ferreira FM, Carvalho MLS, Silva AS, Reis PA, Dórea MC, Silva C, Mota AC, Valls JFM. Poaceae in Lista de Espécies da Flora do Brasil. Jardim Botânico do Rio de Janeiro. Disponível em: <http://floradobrasil.jbrj.gov.br/jabot/floradobrasil/FB193>. Acesso em: 23 Jul. 2014

Filgueiras TS. 1986. O conceito de fruto em gramíneas e seu uso na taxonomia da família. Pesquisa Agropecuária Brasileira 21(2): 93-100.

Garwood NC. 1983. Seed germination in a seasonal tropical forest in Panama: A community study. Ecological Monographs 53: 159-181.

Gashaw M, Michelsen A. 2002. Influence of heat shock on seed germination of plants from regularly burnt savanna woodlands and grasslands in Ethiopia. Plant Ecology 159: 83-93. 
Guerrero AM, Tye A. 2009. Darwin's finches as seed predators and dispersers. The Wilson Journal of Ornithology 121(4): 752-764.

Hoffmann WA, Jaconis S, Mckinley KL, Geiger EL, Gotsch SG, Franco AC. 2012. Fuels or microclimate? Understanding the drivers of fire feedbacks at savanna-forest boundaries. Austral Ecology 37: 634-643.

Howe HF, Smallwood J. 1982. Ecology of seed dispersal. Annual Review of Ecology and Systematics 13: 201-28.

Jurado E, Flores J. 2005. Is seed dormancy under environmental control or bound to plant traits? Journal of Vegetation Science 16: 559-564.

Kauffman JB, Cummings DL, Ward DE. 1994. Relationships of fire, biomass and nutrient dynamics along a vegetation gradient in the Brazilian cerrado. Journal of Ecology 82: $519-531$.

Keya GA. 1997. Environmental triggers of germination and phenological events in an arid savannah region of northern Kenya. Journal of Arid Environments 37: 91-106.

Kobayashi Y, Yamamura N. 2000. Evolution of seed dormancy due to sib competition: Effect of dispersal and inbreeding. Journal of Theoretical Biology 202: 11-24.

Lu J, Tan D, Baskin JM, Baskin CC. 2010. Fruit and seed heteromorphism in the cold desert annual ephemeral Diptychocarpus strictus (Brassicaceae) and possible adaptive significance. Annals of Botany 105: 999-1014.

Mathias A, Kisdi E. 2002. Adaptive diversification of germination strategies. Proceedings of the Royal Society B: Biological Sciences 269: 151-155.

Miranda HS, Sato MN, Neto WN, Aires FS. 2009. Fires in the Cerrado, the Brazilian savanna. In: Cochrane MA (ed.). Tropical fire ecology. Praxis, Chischester, UK, 427450pp. 
Mistry J. 1998. Fire in the cerrado (savannas) of Brazil: an ecological review. Progress in Physical Geography 22(4): 425-448.

Munhoz CBR, Felfili JM. 2007. Reproductive phenology of an herbaceous-subshrub layer of a Savannah (Campo Sujo) in the Cerrado Biosphere Reserve I, Brazil. Brazilian Journal of Biology 67(2):299-308.

Oliveira-Filho AT, Ratter JA. 2002. Vegetation physiognomies and woody flora of the Cerrado Biome. In: Oliveira PS and Marquis RJ (eds.). The cerrados of Brazil: ecology and natural history of a Neotropical savanna. Columbia University Press, New York, US. pp. $121-140$

Overbeck GE, Müller SC, Pillar VD, Pfadenhauer J. 2006. No heat stimulated germination found in herbaceous species from burned subtropical grassland. Plant Ecology 184: 237-243.

Peart MH. 1979. Experiments on the biological significance of the morphology of seed dispersal units in grasses. Journal of Ecology 67: 843-863.

Peart MH. 1981. Further experiments on the biological significance of the morphology of seed-dispersal units in grasses. Journal of Ecology 69: 425-436.

Peart MH. 1984. The effects of morphology, orientation and position of grass diaspores on seedling survival. Journal of Ecology 72: 437-453.

Ramos DM, Diniz P, Valls JFM. 2014. Habitat filtering and interspecific competition influence phenological diversity in an assemblage of Neotropical savanna grasses. Brazilian Journal of Botany 37(1):29-36.

Rees M. 1993. Trade-offs among dispersal strategies in British plants. Nature 366: 15052. 
Rees, M. 1994. Delayed germination of seeds: a look at the effects of adult longevity, the timing of reproduction, and population age/state structure. American Naturalist 144: 4364.

Ribeiro LC, Borghetti F. 2013. Comparative effects of desiccation, heat shock and high temperatures on seed germination of savanna and forest tree species. Austral Ecology 39: $267-278$.

Ribeiro LC, Pedrosa M, Borghetti F. 2012. Heat shock effects on seed germination of five Brazilian savanna species. Plant Biology 15: 1-6.

Rossatto DR, Sternberg LSLO, Franco AC. 2013. The partitioning of water uptake between growth forms in a Neotropical savanna: do herbs exploit a third water source niche? Plant Biology 15:84-92.

Schmidt IB. 2011. Effects of Local Ecological Knowledge, Harvest and Fire on Goldengrass (Syngonanthus nitens, Eriocaulaceae), a non-timber forest product (NTFP) from the Brazilian Savanna. PhD Thesis, University of Hawai'i at Manoa, US.

Scott K, Setterfield S, Douglas M, Andersen A. 2010. Soil seed banks confer resilience to savanna grass-layer plants during seasonal disturbance. Acta Oecologica 36: 202-210. Silberbauer-Gottsberger I. 1984. Fruit dispersal and trypanocarpy in Brazilian cerrado grasses. Plant Systematics and Evolution 147(1-2): 1-27.

Silva JF, Ataroff M. 1985. Phenology, seed crop and germination of coexisting grass species from a tropical savanna in Western Venezuela. Acta Oecologica 6(20): 41-51.

Tannus JLS, Assis MA, Morellato LPC. 2006. Fenologia reprodutiva em campo sujo e campo úmido numa área de cerrado no sudeste do Brasil, Itirapina-SP. Biota Neotropica 6:1-27.

Thompson K. 1987. Seeds and seed banks. New Phytologist 106(1): 23-34. 
van der Pijl L. 1982. Principles of dispersal in higher plants. 3rd ed. Springer Verlag, New York.

Venable DL, Brown JS. 1988. The Selective Interactions of Dispersal, Dormancy, and Seed Size as Adaptations for Reducing Risk in Variable Environments. The American Society of Naturalists 131(3): 360-384.

Zuloaga FO, Morrone O. 2003. Echinolaena. In: Catalogue of New World Grasses (Poaceae): III. Subfamilies Panicoideae, Aristidoideae, Arundinoideae, and Danthonioideae. Contr. U.S. Natl. Herb. 46: 224-225. (http://www.tropicos.org/NamePage.aspx?nameid=25517386\&projectid=10). 
CAPÍTULO 1

Avoiding the dry season: dispersal time and syndrome mediate seed dormancy in Neotropical savanna grasses 
Avoiding the dry season: dispersal time and syndrome mediate seed dormancy in

\section{Neotropical savanna grasses}

Desirée M. Ramos ${ }^{1,5^{*}}$; Pedro Diniz ${ }^{2}$; Mark K. J. Ooi ${ }^{3,4}$; Fabian Borghetti ${ }^{1}$ and José F. M. Valls $^{1,5}$

1 - Department of Botany - University of Brasília/Brazil; 2 - Department of Ecology University of Brasília; 3 - Centre for Sustainable Ecosystem Solutions, School of Biological Sciences - University of Wollongong/Australia; 4 - Centre for Ecosystem Science, School of Biological, Earth and Environmental Sciences, University of New South Wales/Australia; 5 - Brazilian Corporation of Agricultural Research/Embrapa, Brasília/Brazil.

Correspondence:

D. M. Ramos, Embrapa Recursos Genéticos e Biotecnologia. Parque Estação Biológica PqEB, s/no. Caixa Postal 02372, P.O Box: 70770-900. Brasília, Distrito Federal, Brazil.

E-mail: desibio@gmail.com 


\section{Abstract}

2 - Background and Aims: Seed dormancy is often viewed as a strategy to avoid seed

3 germination in dry periods in plants from seasonal rainfall environments and also

4 trades-off with seed dispersal syndrome, because both can be costly strategies to avoid

5 crowding and sibling competition. Grass species in Brazilian savannas (Cerrado) show

6 large variation in habitat type, seed dispersal times, syndromes and live in a rainfall

7 seasonal environment. Our aims are to test dormancy levels and seed germination

8 comparing seeds: (1) dispersed under different times (early rainy season, late rainy season and dry season); (2) living in habitats with contrasting soil moisture during the dry season (open savannas versus wet grasslands), and (3) showing opposite dispersal syndromes (barochoric versus anemochoric). We expected to find the highest dormancy levels in late rainy season dispersed seeds, wet grasslands and barochory (short dispersal) seeds.

- Methods We investigated viability, dormancy and germination of fresh seeds and after dry storage (3, 6, 9 and 12 months) of 29 grass species from open savannas and wet grasslands of Central Brazil.

- Key Results Grass seed dormancy varied with seed dispersal timing and syndrome, and habitat seasonality. First, fresh seeds dispersed late in the rainy season had higher levels of seed dormancy compared to the early dispersed seeds. Second, seeds from wet grasslands lived longer and had constant higher germination rates than seeds from open savannas. Finally, we found that anemochoric seeds had less dormancy than barochoric seeds.

- Conclusions We found that indeed seed dormancy is higher prior to the dry season, in dry habitats and in short dispersed (barochory) seeds for grasses in Brazilian savannas. These results suggest seed dormancy probably avoid costly seedling recruitment in the 
26 dry season and this effect seems to be attenuated by habitat specific soil moisture. Seed

27 dormancy traded-off with seed dispersal, which suggests both strategies are costly and 28 had non-additive benefits.

29 Key words: Cerrado, dry storage, germination, open savanna, Poaceae, wet grassland. 30 
Savannas are biomes composed of a continuous grass layer and scattered trees, under a seasonal climate consisting of an annual cycle of wet and dry seasons (Scholes and Archer, 1997). The Cerrado is a Neotropical biome in Central Brazil composed mostly of savannas but also includes grasslands and forests. Soil moisture is one of the main determinants of vegetation physiognomies; for example, rain forests are associated with waterfalls and riparian areas while wet grasslands occur where the water table reaches close to the surface. In both of these examples, soils are moist throughout the year. However, in savannas the water table sits deeper below the soil surface, leading to soils and the herbaceous layer drying out during the annual dry season. Grass species within the Cerrado biome are mostly restricted to the open physiognomies of savannas and grasslands due to their shade intolerance.

In savannas, rainfall seasonality is among the major limiting factors determining seed germination and seedling establishment, due to its direct effects on water availability in the soil (Jurado and Flores, 2005; Baskin and Baskin, 2014). Rainfall seasonality is therefore likely to be a strong selective pressure acting on seed dormancy, and indeed seed dormancy has been found in a higher number of species in seasonal rainfall environments in comparison to less seasonal environments (Jurado and Flores, 2005; Baskin and Baskin, 2014).

Grasses are one of the most highly represented families (Poaceae) in the herbaceous layer of the Cerrado (around 600 species, Filgueiras et al., 2014). Grasses occurring in savanna physiognomies of the Cerrado are subjected to seasonal variation in soil water availability throughout the year. For most species the flowering and fruiting periods are restricted to the rainy season (Tannus et al., 2006; Munhoz and Felfili, 2007; Ramos et al., 2014), presumably as a strategy to avoid water shortage 
during the dry season. However, there is large variation in the timing of seed dispersal among grass species (Almeida, 1995; Munhoz and Felfili, 2007; Ramos et al., 2014), with some species dispersing early in the wet season, others dispersing later, and some species dispersing seeds even during the dry season (Almeida, 1995). Seeds dispersed early in the wet season would have the entire growing season to germinate and recruit, whereas seeds dispersed late in the wet season, or during the dry season, would very probably face extreme water shortages, which potentially could be a risky strategy for seedling survival. Avoiding germination prior to and during the dry season would be a key strategy for reducing the probability of seedling mortality during the dry season, and seed dormancy would therefore play an important role in delaying seed germination to the next wet season. Consequently, we would expect deeper seed dormancy among seeds dispersed late in the rainy season, and during the dry season, in comparison to seeds dispersed early in the rainy season for species from savanna habitats. In contrast, in wet grasslands the water table is situated near the surface throughout the year (Cianciaruso and Batalha, 2008; Meirelles et al., 2010) and hence the impact of rainfall seasonality in the soil is buffered by the water table and the soil surface stays moist for longer during the dry season (Cianciaruso and Batalha, 2008; Meirelles et al., 2010). Subsequently, if seed dormancy is a strategy of species from seasonal environments to deal with water shortage, this selective pressure would be weaker in wet grasslands. Thus, we would expect a deeper seed dormancy among seeds of species occurring in open savannas in comparison to seeds of species occurring in wet grasslands.

While the season of seed release may be an important driver for variation in dormancy, dispersal also plays a critical role determining the level of competition faced by emerging seedlings. In broad terms, seed dormancy can reduce extinction risk by spreading germination over time (Bulmer, 1984), while seed dispersal can reduce risk 
by spreading seeds and, consequently, germination over space (Venable and Brown, 1988). Parent-offspring (Ellner, 1986) and sibling competition can significantly reduce plant fitness (Satterthwaite, 2010; Baskin and Baskin, 2014; Saatkamp et al., 2014).

Both seed dormancy and dispersal are costly strategies, thus a trade-off between seed dormancy and dispersal is often reported between these two bet-hedging traits (Venable and Brown, 1988). Theoretical studies in particular have reported that mean dispersal distance decreases with increasing dormancy (e.g. Venable \& Lawler, 1980; Cohen \& Levin, 1991), although this relationship is not always supported where positive temporal correlations in environment exist (Snyder, 2006). Nevertheless, few empirical assessments of the trade-off between dormancy and dispersal have been made (Rees, 1993).

The diaspore morphology of savanna grass species is highly variable, and among several dispersal syndromes, seeds can be characterized by structures which facilitate wind dispersal (anemochory) such as winged bracts, hairy bracts and hairy rachis, or these structures can be completely absent and dispersal probably occurs through gravity (barochory) (Silberbauer-Gottsberger, 1984; Ernst et al., 1992). Barochoric seeds fall near the mother-plant, while anemochoric seeds have the opportunity to disperse far from the mother-plant. Thereby, anemochory could be favoured to deal with spatial unpredictability and competition. Hence, we would expect to find a deeper seed dormancy among barochoric seeds in comparison to anemochoric seeds if there was support for a dispersal-dormancy trade-off.

The seasonal climate of the Brazilian savanna, the micro-climatic differences in their physiognomies as a consequence of variations of the water table, and the high variability in seed dormancy and dispersal syndromes of savanna grasses make the Cerrado an ecological system to investigate germination strategies. Thus, our aims were 
to test dormancy levels and seed germination comparing seeds: (1) dispersed under different times (early rainy season, late rainy season and dry season); (2) living in habitats with contrasting soil moisture during the dry season (open savannas versus wet grasslands), and (3) displaying opposing dispersal syndromes (barochoric versus anemochoric). We expected to find the highest dormancy levels in late rainy season dispersed seeds, wet grasslands and barochoric (short dispersal) seeds.

\section{MATERIALS AND METHODS}

Study area and seed collection

The Cerrado is the largest Neotropical savanna and covers around 2 million square kilometers in Central Brazil. The dispersal units in grasses are generally complex structures composed of a caryopsis (fruit), a caryopsis with bracts (lemma and palea) or occasionally a caryopsis with inflorescence structures attached (hereafter called seeds).

Seeds of 28 native perennial grass species and one annual Digitaria lehmanniana (Table

1) from Brazilian open savannas and wet grasslands were collected in 2012 and 2013, in two protected areas of Brasília: Fazenda Água Limpa at the University of Brasília (FAL - 15 58'43.06"S and 47 56'21.41"W, $1.197 \mathrm{~m}$ ) and the National Park of Brasília (PNB $15^{\circ} 38^{\prime} 46.22^{\prime \prime S}$ and $\left.48^{\circ} 00^{\prime} 19.75^{\prime \prime} \mathrm{W}, 1.178 \mathrm{~m}\right)$. For an accurate identification we collected vouchers of the studied grass species, which were deposited in the Embrapa Genetic Resources and Biotechnology (CEN) Herbarium, headquartered in Brasilia. The climate of the region is seasonal with two well defined seasons: a wet season from October to March (mean annual precipitation from 800 to 2000 mm; Oliveira-Filho and Ratter, 127 2002) and a dry season from April to September (Fig. 1). The study sites are composed of patches of savanna, forest and grassland. Vegetation in open savannas and wet grasslands are composed mainly of grasses and forbs, with a few scattered trees 
occasionally visible in the first case. Soils in open savannas are well drained, poor in nutrients and rich in aluminum. On the other hand, soils in wet grasslands are rich in organic matter and the water table sits near the surface (about 20-80 cm) (Cianciaruso and Batalha, 2008; Meirelles et al., 2010), making the soil moist for most of the year (Cianciaruso and Batalha, 2008; Fidelis et al., 2013).

Plants were monitored regularly to ensure that seeds were mature at dispersal and then collected by hand. After collection the seeds were stored in paper bags at room temperature $\left(27^{\circ} \mathrm{C}\right.$-maxima and $17^{\circ} \mathrm{C}$-minima), measured throughout dry storage with a thermometer. The average relative air humidity in the region (Distrito Federal) was $43-80 \%$ during the period of study (data from BDMEP/INMET).

To characterize the soil moisture of the studied areas (FAL and PNB) we measured the water potential (in Megapascals $-\mathrm{MPa} / \Psi$ ) of six sites of open savannas and four sites of wet grasslands every 30 days during the dry season, from June to August in 2015. Soil samples were collected during the dry season to verify whether soils of wet grasslands stay wet for longer than soils of open savannas after the end of the rainy season. We collected soil samples in three plots previously set in each area equidistant $50 \mathrm{~m}$ from each other in a triangle arrangement, totally 18 plots in open savannas and 12 plots in wet grasslands. The plots were divided into three subsamples, one for each month of collection. In each subsample soil samples were collected at two depths: between 2 to 3 centimeters and between 10 to 11 centimeters. These depths were selected because 1) most seeds in the soil seed banks in Brazilian savannas were shown to occur in first centimeters underground (Andrade et al., 2002; Zago de Andrade and Miranda, 2014) and 2) root biomass of grasses were shown to occur mostly between 0 to 20cm depth in Brazilian grasslands (Castro and Kauffman, 1998; Fidelis et al., 2013), so a depth between 2 to $11 \mathrm{~cm}$ is well within the perfil-position 
roots of grass seedlings would be found in the case of germination. The soil samples were placed in hermetically sealed sample cups, and as soon as possible the water potential of each sample was measured in the laboratory with WP4C water potential meter (Decagon Devices, Pullman-USA, 2015).

\section{Dispersal syndrome and seed dispersal time}

Based on external morphology of dispersal structure, the seeds were categorized as either anemochoric and barochoric (van der Pijl, 1982). We considered as anemochoric those seeds presenting structures that facilitate dispersal by wind, like winged bracts and/or presenting hairs in the bracts. Seeds without winged bracts or hairs were considered barochoric (Table 1). The monitoring of the grass populations selected for this study allowed us to estimate the periods of seed dispersal for each species. Thus, we divided the grass species in three groups: a) species dispersing early in the rainy season (October to January); b) species dispersing late in the rainy season (February to April) and c) species dispersing in the dry season (May to September).

\section{Dormancy level of freshly harvested and stored seeds}

To determine the level of dormancy and to test the effect of dry storage on the degree of dormancy, viability and germination of the seeds for each species' germination trial were conducted with both freshly collected seeds as well as with seeds stored for three, six, nine and twelve months. The germination experiments were conducted in germination chambers regulated for $28 / 18^{\circ} \mathrm{C}$ cycle at day/night temperatures, respectively, under a photoperiod of $12 \mathrm{~h}$ of white light. These temperatures were set according to the average minimum and maximum temperatures recorded during the wet season (Fig. 1), which represents the growing season for most savanna species in the Cerrado, including grasses. Seeds were placed in petri dishes lined with two sheets of filter paper and moistened with distilled water. The germination 
was recorded daily up to 30 days, using the radicle emergence as a criterion for seed germination. Five replicates of 20 seeds were used for each species for each treatment, except for P. maculosum, A. goyazense, H. longispicula and S. sanguineum, which were used five replicates of 10 seeds per treatment due to the limited quantity of seeds. After each germination trial, the viability of the non-germinated seeds was tested using $1 \%$ tetrazolium chloride solution. For that, the remaining seeds were placed in contact with tetrazolium solution for 24 hours in dark at $30{ }^{\circ} \mathrm{C}$ in a germination chamber. We considered as viable the seeds which embryos were dark pink or red. The total viability of each seed sample was set as the number of germinated seeds during the experiments plus the positive results of tetrazolium test.

\section{Statistical analysis}

All analysis were done using the R 3.1.2 statistical software ( $\mathrm{R}$ Core Team 2014). We used Generalized Linear Mixed Models (GLMM, binomial distribution, see Zuur et al., 2009) (R package: lme4; see Bates et al., 2014) to test whether the effect of storage treatments on seed viability and germination is dependent on seed dispersal time (early or late in the rainy season and in the dry season), seed dispersal strategy (anemochoric or barochoric) and habitat of seed collection (open savannas or wet grasslands). We analysed seed viability and germination (presence/absence) as the response variables, separately. In this analysis, we used each seed as an experimental unit. We included a two-way interaction term between habitat, seed dispersal time and seed dispersal strategy and dry storage treatment (zero, three, six, nine and twelve months), as fixed independent variables. We included genus, species and replication as nested random factors in all models. As the seeds placed inside the petri dishes are under the same environment, which can result in autocorrelation of errors (Sileshi, 2012), we included the replication ( $N=5$ per species) at the random component of the 
model in order to control for autocorrelation of errors. As all interactions were significant, it was not necessary to perform a model selection, so we made only a single step with the full model. We made post-hoc pairwise comparisons between levels of the significant fixed factors: dry storage and habitat, dry storage and seed dispersal time and dry storage and seed dispersal strategy. We used the single step method to P-values adjustment and the glht command of multcomp package for the pairwise comparisons (Hothorn et al., 2008).

To analyse the differences in soil water potential of wet grasslands and open savannas during the dry season months we also used Generalized Linear Mixed Models (GLMM, normal distribution, see Zuur et al., 2009). As we intended to test the differences in soil water potential between vegetation in each month, we made a model for each month separately. We used the water potential as response variable and as fixed independent variables a two-way interaction between vegetation (wet grassland or open savanna) and depth (2-3 or $10-11 \mathrm{~cm})$. We included the studied areas (FAL or PNB) and plots ( 3 per site) nested as random factors in models. As the water potential did not follow a normal distribution and range from negative to zero values, we made a transformation lognormal +1 to normalize it and we add +1 due to zeros present in the data. As is not possible to transform negative values in lognormal we reflected the data, multiplying by -1 , to change it to positive before perform the lognormal transformation. We made post-hoc pairwise comparisons between levels of the significant fixed factors: vegetation and depth. We used the single step method for P-values adjustment and the glht command of multcomp package for the pairwise comparisons (Hothorn et al., 2008). 


\section{Habitat seasonality and germination}

The soil water potential at each depth differed between vegetation types with exception of $10-11 \mathrm{~cm}$ in June and July (Table 2). In wet grasslands the soil water potential was higher than in open savannas for all dry season months (Fig. 2). The mean soil water potential at shallower depths $(2-3 \mathrm{~cm})$ was higher in wet grasslands than in open savannas, ranging from -0.5 MPa (June) to -1.2 MPa (August) and from -3.2 $\mathrm{MPa}$ (June) to -5 MPa (August), respectively (Fig. 2).

The germination of grass seeds during dry storage was influenced by habitat of seed collection $\left(\mathrm{LRT}_{4}=27.583, P<0.001 ;\right.$ Fig. 3$)$. The germination among species from open savannas increased after six months of dry storage and stayed constant until twelve months of dry storage (Table 3; Fig. 3). On the other hand, the germination increased faster among species from wet grasslands, after three months of dry storage, and also stayed constant until twelve months of dry storage (Table 3; Fig. 3). Similar to seed germination, seed viability response along the storage time was also influenced by species habitat $\left(\mathrm{LRT}_{4}=10.323, P<0.05\right)$. In open savannas the seed viability was lower after nine $(\beta=-0.57, P<0.05)$, and twelve $(\beta=-0.75, P<0.05)$ months of dry storage in comparison to freshly collected seeds, while in wet grasslands the seed viability did not differ during the storage time (Table 3; Table S1 - supplementary data).

\section{Dormancy level comparison against dispersal time and dispersal syndrome}

The germination of grass seeds during dry storage was influenced by the seed dispersal time $\left(\mathrm{LRT}_{8}=110.738, P<0.001 ;\right.$ Fig. 4). Freshly collected seeds dispersed early in the rainy season and in the dry season had higher probability of germination than seeds dispersed late in the rainy season (Table 3; Fig. 4). After three months of dry 
storage the probability of germination was not influenced by the dispersal time of the seeds (Fig. 4). The viability between seed dispersal times differ in six months of dry storage, in which early-dispersed seeds had lower viability than late dispersed seeds in the rainy season $(\beta=-0.9635, P<0.05$; Table $\mathrm{S} 4$ - supplementary data). In addition, after twelve months of dry storage the viability of early-dispersed seeds was lower than latedispersed seeds $(\beta=-0.9258, P<0.05$; Table $\mathrm{S} 4$ - supplementary data) and of seeds dispersed in the dry season $(\beta=-2.2161, P<0.001$; Table $S 4$ - supplementary data). We found a significant effect of seed dispersal syndrome $\left(\mathrm{LRT}_{4}=28.785\right.$, $P<0.001$; Fig. 5) on germination probability during dry storage. The germination in barochoric seeds was lower than in anemochoric ones for freshly collected seeds and also after three months of dry storage (Table 3; Fig. 5). After six months of dry storage the probability of germination was no longer influenced by the seed dispersal syndrome (Fig. 5). The viability of barochoric and anemochoric seeds did not differ (Table S2 supplementary data), except at six months of dry storage, when barochoric seeds showed a lower viability than anemochoric seeds (Table $3 ; \beta=-0.7955, P<0.05$ ).

\section{DISCUSSION}

There were contrasting effects of dry storage on the germination and viability of species from open savannas and wet grasslands. In open savannas the germination of fresh seeds was low, increasing after six months, followed by seed mortality after nine months of storage. These results indicate that germination in seeds of species from open savannas may be delayed, at most, until the onset of the next rainy season. On the other hand, seeds of species from wet grasslands were longer-lived than seeds from open savannas, remaining viable after one year of dry storage. Additionally, germination levels increased and stayed constant high after three months of dry storage. 
In wet grasslands, the soil remained wet during the dry season in comparison to open savannas, presenting values around $-1 \mathrm{MPa}$ at 2 to $3 \mathrm{~cm}$ depth (Fig. 2). Water potential of around -1 MPa is not limiting for the germination of grass species (Qui and Redmann 1993), thus suggesting that the water potential measured in the wet grasslands studied here would not limit the germination of seeds present in the soil. Moreover, the soil moisture and the high percentages of germination of grass species from wet grasslands suggest that germination might occur even during the dry season.

Although water seasonality does not seem to be a strong selective pressure on seed germination of species from wet grasslands, due to the high soil moisture even during the dry season, another factor, such as the pressure of stablished vegetation, has been demonstrated to negatively influence seedling establishment in savannas (Zimmermann et al., 2008). Wet grasslands can be strongly competitive environments for seedlings, as they have dense and closed aboveground plant biomass of around 765 $\mathrm{g} \mathrm{m}^{-2}$ (Fidelis et al., 2013). Fire frequently occurs in wet grasslands and can reduce competition by removing the established vegetation (Zimmermann et al., 2008). The high longevity of seeds, combined with high germination rates, of grass species from wet grasslands can result in an opportunistic strategy for taking advantage of gaps, for example after a fire event, to allow growth and establishment in a less competitive environment.

\section{Seed dormancy at the end of the rainy season may avoid risky germination}

We show that seed dormancy is related to the dispersal time of Neotropical grass species (Fig. 4). Seeds dispersed late in the rainy season showed lower probability of germination than seeds dispersed either early in the rainy season, or dispersed during the dry season. The high levels of dormancy among late dispersed seeds may represent a drought-avoidance syndrome, a strategy already observed among grass species of 
savanna environments (Mott, 1978; Veenendaal et al., 1996; O'Connor and Everson, 1998; McIvor and Howden, 2000; Scott et al., 2010). Seeds dispersed in the beginning of the rainy season are expected to have about seven months to germinate and establish.

On the other hand, seed germination at the end of the rainy season would be very risky, since the seedlings would not have time enough to grow and acquire a minimal size to enable them to tolerate the harsh conditions expected during the dry season. Thus, the presence of seed dormancy here might prevent germination during times of low chances of recruitment, and hold back emergence to the onset of the next rainy season.

Contrary to our expectations, the germination of seeds dispersed in the dry season was not different from seeds dispersed early in the rainy season. Seeds dispersed during the dry season showed low levels of seed dormancy. Since sporadic rains are expected to occur in the dry season (Fig. 1), we did not expected to find high germination in seeds dispersed in the dry season. However, the amount of rain is extremely low (Fig. 1) and potentially not sufficient to induce the start of germination. Additionally, the next rainy season is close and, by not having seed dormancy, these dry season dispersed seeds may rapidly germinate and take advantage of the entire growing season to establish.

\section{Trade-off between seed dispersal and level of dormancy}

We found a negative relationship between seed dispersal and seed dormancy. Anemochoric seeds germinated to significantly greater levels and (consequently) had lower levels of dormancy than barochoric seeds. As far as we know, this is the first study to demonstrate the trade-off between seed dispersal and dormancy across species from the same family (Poaceae). Moreover, most of both the theoretical and empirical studies investigating the evolution of seed dispersal and seed dormancy have been made for plants from unpredictable environments, mostly in deserts (Volis and Bohrer, 2013). 
Our between-species comparison in a seasonally wet ecological system provide

327

empirical results showing that barochoric grass seeds are significantly more dormant than anemochoric ones.

Seed dispersal and seed dormancy may be viewed as bet-hedging strategies to enable species to cope with environmental patch heterogeneity and climatic unpredictability (Bulmer, 1984; Venable and Brown, 1988), the former by spreading risk over time (Bulmer, 1984), and the latter by spreading risk over space (Venable and Brown, 1988). However, even in the absence of patch heterogeneity, seed dispersal can be favoured by kin selection (Venable and Brown, 1988). Additionally, in environments without inter-annual variation in precipitation, seed dormancy can be advantageous where sibling competition is high (Volis and Bohrer, 2013). Although water availability affects seedling establishment in savannas (Medina and Silva, 1990; Davis et al., 1999; Sharam et al., 2006; Higgins et al., 2000) and might explain seed dormancy, it does not explain our results that anemochoric seeds had lower seed dormancy than barochoric seeds. In open savannas and wet grasslands of the Cerrado there is no clear patch heterogeneity, as exists in deserts, so it is less likely that this has driven a seed dispersal-dormancy trade-off in our studied species. Alternatively, we suggest that competition between siblings, conspecifics or heterospecifics, might drive the dispersaldormancy trade-off that we found in our study species.

Conspecific competitor densities during seedling growth negatively influences plant fitness (Orrock and Christopher, 2010). By dispersing far and not being dormant, grass seeds with an anemochoric dispersal strategy might enhance the chances of a seed landing in a more open patch, enabling it to take advantage of sites with lower competition for resources. Moreover, fire is a frequent disturbance in Brazilian open savannas and wet grasslands, and fire occurrence can open up gaps in the herbaceous 
vegetation. As such, these anemochoric species may be favored by germinating earlier and growing in gaps opened by fire events. In contrast, the outcome for barochoric seeds is that they fall near to the mother plant and siblings. Because they disperse throughout the rainy season, there is sufficient moisture to enable seed germination, and seedlings could grow in clumps if no other mechanism were available. Thus, seed dormancy can be a way to reduce immediate germination and distribute seedling emergence over time. Alternatively, deeper dormancy among barochoric seeds could give seeds more time to enable a secondary dispersal event. Indeed, some of the barochoric grass species studied have structures recognized to favor secondary dispersal, including Echinolaena inflexa and Icnanthus camporum, which both have elaiosomes that are known to attract ants. Furthermore, Aristida species have awns, which can attach to rodents providing potential longer-distance dispersal. In conclusion, our results show that seed dormancy is a strategy to synchronize with a large representative number of grass species from Neotropical savannas that seed dormancy is a critical life history trait that allows persistence in seasonal environments with dry periods. Moreover, our results also provide empirical evidence for a trade-off between seed dispersal and seed dormancy. These results indicate that rainfall seasonality is not the only selective pressure driving evolution of seed dormancy in grass species and we suggest that competition can have an important influence selecting for the germination timing of seeds from seasonal and predictable environments. 
We acknowledge CAPES, University of Brasília and Embrapa for the financial

377 support to this study. José F. M. Valls was supported by a CNPq Scholarship during this

378 study. We thank to Eduardo M. Barbosa and Augusto C. Franco for their helpful

379 comments in the previous version of this paper. We thank to the field assistants Vanessa

380 Barros Fujiyama and Fernanda de Lacerda e Silva for their work in the field and

381 laboratory. Mark Ooi was supported by an Australian Research Council Linkage Project

382 grant (LP110100527) during this study. We confirm that there are no known conflicts of 383 interest associated with this publication.

Allem AC, Valls JFM. 1987. Recursos Forrageiros Nativos do Pantanal Matogrossense. Brasília: EMBRAPA/DID. (EMBRAPA/CENARGEN. Documentos, 8). 339 p.

ALMEIDA SP. 1995. Grupos fenológicos da comunidade de gramíneas perenes de um campo Cerrado no Distrito Federal. Pesquisa Agropecuária Brasileira 30: 1067-1073.

Andrade LAZ, Neto WN, Miranda HS. 2002. Effects of fire on the soil seed bank in a Cerrado sensu stricto in central Brazil. In: Viegas DX (ed) Forest fire research and wildland fire safety. Millpress, Roterdam.

Baskin CC, Baskin JM. 1998. Ecology of seed dormancy and germination in grasses. In: Cheplick GP, ed. Population Biology of Grasses. Cambridge University Press. Baskin CC, Baskin JM. 2014. Seeds: Ecology, Biogeography, and Evolution of Dormancy and Germination. Academic Press. a new Brazilian vegetation form. Brazilian Journal of Biology 65(4): 735-738. 
Bates D, Maechler M, Bolker B, Walker S. 2014. _lme4: Linear mixed-effects models

400 using Eigen and S4_. R package version 1.1-7, <URL: http://CRAN.R-

401 project.org/package=lme4>.

402

Bulmer MG. 1984. Delayed germination of seeds: Cohen's model revisited. Theoretical

403

404

405

406

407

408

409

410

411

412

413

414

415

416

417

418

419

420

421

422

423 Population Biology, 26: 367-377.

Castro EA, Kauffman JB. 1998. Ecosystem structure in the Brazilian Cerrado: a vegetation gradient of aboveground biomass, root mass and consumption by fire. Journal of Tropical Ecology, 14: 263-283.

Cianciaruso MV, Batalha MA. 2008. A year in a Cerrado wet grassland: a non-seasonal island in a seasonal savanna environment. Brazilian Journal of Biology, 68(3): 495-501. Cohen D, Levin SA. 1991. Dispersal in patchy environments: the effects of temporal and spatial structure. Theoretical Population Biology, 39: 63-99.

Davis MA, Wrage KJ, Reich PB, Tjoelker M, Schaeffer T, Muermann C. 1999. Survival, growth, and photosynthesis of tree seedlings competing with herbaceous vegetation along a water-light-nitrogen gradient. Plant Ecology 145: 341-350.

Donohue K, de Casas RR, Burghardt L, Kovach K, Willis CG. 2010. Germination, postgermination adaptation, and species ecological ranges. Annual Reviews: Ecology, Evolution and Systematics 41: 293-319.

Ellner S. 1986. Germination dimorphisms and parent-offspring conflict in seed germination. Journal of Theoretical Biology 123: 173-185.

Ernst WHO, Veenendaal EM, Kebakile MM. 1992. Possibilities for Dispersal in Annual and Perennial Grasses in a Savanna in Botswana. Vegetatio 102(1): 1-11.

Fidelis A, Lyra MFS, Pivello VR. 2013. Above- and below-ground biomass and carbon dynamics in Brazilian Cerrado wet grasslands. Journal of Vegetation Science 24:356364. 

Botânico do Rio de Janeiro. Available in: <http://floradobrasil.jbrj.gov.br/jabot/floradobrasil/FB193>. Accessed: 23 Jul. 2014 Higgins SI, Bond WJ, Trollope WS. 2000. Fire, resprouting and variability: a recipe for grass-tree coexistence in savanna. Journal of Ecology 88: 213-29.

Hothorn T, Bretz F, Westfall P. 2008. Simultaneous Inference in General Parametric Models. Biometrical Journal 50, 346-363.

Jurado E, Flores J. 2005. Is seed dormancy under environmental control or bound to plant traits? Journal of Vegetation Science 16: 559-564.

Keya GA. 1997. Environmental triggers of germination and phenological events in an arid savannah region of northern Kenya. Journal of Arid Environments 37: 91-106. Kobayashi Y, Yamamura N. 2000. Evolution of Seed Dormancy Due to Sib Competition: Effect of Dispersal and Inbreeding. Journal of theoretical Biology 202: 1124.

Lu J, Tan D, Baskin JM, Baskin CC. 2010. Fruit and seed heteromorphism in the cold desert annual ephemeral Diptychocarpus strictus (Brassicaceae) and possible adaptive significance. Annals of Botany 105: 999-1014.

Lu JJ, Tan DY, Baskin JM, Baskin CC. 2013. Trade-offs between seed dispersal and dormancy in an amphi-basicarpic cold desert annual. Annals of Botany 112(9): 18151827. 
Lundberg S, Nilsson P, Fagerstrogöm T. 1996. Seed dormancy and frequency

448 dependent selection due to sib competition: the effect of age specific gene expression. Journal of theoretical Biology 183: 9-17.

450

McIvor JG, Howden SM. 2000. Dormancy and germination characteristics of

451

452

453

454

455

456

457

458

459

460

461

462

463

464

465

466

467

468

469

470

471 herbaceous species in the seasonally dry tropics of northern Australia. Austral Ecology 25: $213-222$.

Medina E, Silva JF. 1990. Savannas of Northern South America: A Steady State Regulated by Water-Fire Interactions on a Background of Low Nutrient Availability. Journal of Biogeography 17: 403-413.

Meirelles ML, Franco AC, Frerreira EAB, Randow CV. 2010. Fluxo diurno de CO2 solo-planta-atmosfera em um campo úmido do cerrado. Boletim de Pesquisa e Desenvolvimento, 274, Embrapa Cerrados, Planaltina.

Mott JJ. 1978. Dormancy and germination in five native grass species from savannah woodland communities of the northern territory. Australian Journal of Botany 26: 621631.

Munhoz CBR, Felfili JM. 2007. Reproductive phenology of an herbaceous-subshrub layer of a Savannah (Campo Sujo) in the Cerrado Biosphere Reserve I, Brazil. Brazilian journal of biology 67(2):299-308.

O’Connor TG, Everson TM. 1998. Population dynamics of perennial grasses in African savanna and grassland. In: Cheplick GP, ed. Population Biology of Grasses. Cambridge University Press, Cambridge, pp. 333-65.

Oliveira PE, Gibbs PE. 2000. Reproductive biology of woody plants in a cerrado community of Central Brazil. Flora 195:311-329.

Oliveira-Filho AT, Ratter JA. 2002. Vegetation physiognomies and woody flora of the Cerrado Biome. In: Oliveira PS, Marquis RJ (eds.). The cerrados of Brazil: ecology and 
473 121-140.

474 Orrock JL, Christopher CC. 2010. Density of intraspecific competitors determines the

475

476

477

478

479

480

481

482

483

484

485

486

487

488

489

490

491

492

493

494

495

occurrence and benefits of accelerated germination. American Journal of Botany 97(4): 694-699.

Qi MQ, Redmann RE. 1993. Seed germination and seedling survival of C3 and C4 grasses under water stress. Journal of Arid Environments 24: 277-285.

R Development Core Team. 2014. R: A language and environment for statistical computing. R Foundation for Statistical Computing, Vienna, Austria. URL

http://www.R-project.org/.

Ramos DM, Diniz P, Valls JFM. 2014. Habitat filtering and interspecific competition influence phenological diversity in an assemblage of Neotropical savanna grasses. Brazilian Journal of Botany 37(1): 29-36.

Ramos-Neto MB, Pivello VR. 2000. Lightning Fires in a Brazilian Savanna National Park: Rethinking Management Strategies. Environmental Management 26: 675-684.

Rees M. 1993. Trade-offs among dispersal strategies in British plants. Nature 366: 15052.

Rossatto DR, Silva LCR, Villalobos-Vega R, Stenberg LSL, Franco AC. 2012. Depth of water uptake in woody plants relates to groundwater level and vegetation structure along a topographic gradient in a Neotropical savanna. Environmental and Experimental Botany 77:259-266.

Saatkamp A, Poschlod P, Venable DL. 2014. The Functional Role of Soil Seed Banks in Natural Communities. In: Gallagher RS Ed. Seeds: The Ecology of Regeneration in Plant Communities. Wallingford, UK: CABI Publishing. 

dispersal and dormancy, rather than persistent soil seed-bank, control seedling recruitment of woody plants in Neotropical savannas. Seed Science Research 21:103116.

Satterthwaite WH. 2010. Competition for space can drive the evolution of dormancy in a temporally invariant environment. Plant Ecology 208: 167-185.

Scholes RJ, Archer SR. 1997. Tree-grass interactions in savannas. Annual Review of Ecology and Systematics 28:517-544.

Scott K, Setterfield S, Douglas M, Andersen A. 2010. Soil seed banks confer resilience to savanna grass-layer plants during seasonal disturbance. Acta Oecologica 36: $202-210$.

Sharam G, Sinclair ARE, Turkington R. 2006. Establishment of Broad-leaved Elephants. Biotropica 38(5): 599-605.

Silberbauer-Gottsberger I. 1984. Fruit dispersal and trypanocarpy in brazilian cerrado grasses. Plant Systematics and Evolution 147 (1-2):1-27.

Sileshi GW. 2012. A critique of current trends in the statistical analysis of seed germination and viability data. Seed Science Research 22: 145-159. species from a tropical savanna in Western Venezuela. Acta Ecologica 6(20): 41-51.

516 Snyder RE. 2006. Multiple risk reduction mechanisms: can dormancy substitute for 517 dispersal? Ecology Letters 9:1106-1114.

Tannus JLS, Assis MA, Morellato LPC. 2006. Fenologia reprodutiva em campo sujo e campo úmido numa área de cerrado no sudeste do Brasil, Itirapina-SP. Biota Neotropica 6:1-27. 
van der Pijl L. 1982. Principles of dispersal in higher plants. 3rd ed. Springer Verlag,

522

523

524

525

526

527

528

529

530

531

532

533

534

535

536

537

538

539

540

541

542

543

544

545

New York.

Veenendaal EM, Ernst WHO, Modise GS. 1996. Effect of seasonal rainfall pattern on seedling emergence and establishment of grasses in a savanna in south-eastern Botswana. Journal of Arid Environments 32:305-317.

Venable DL, Brown JS. 1988. The Selective Interactions of Dispersal, Dormancy, and Seed Size as Adaptations for Reducing Risk in Variable Environments. The American Society of Naturalists 131(3): 360-384.

Vitalis R, Rousset F, Kobayashi Y, Olivieri I, Gandon S. 2013. The joint evolution of dispersal and dormancy in a metapopulation with local extinctions and kin competition. Evolution 67(6): 1676-1691.

Volis S, Bohrer G. 2013. Joint evolution of seed traits along an aridity gradient: seed size and dormancy are not two substitutable evolutionary traits in temporally heterogeneous environment. New Phytologist 197(2): 655-667.

Wang JH, Baskin CC, Cui XL, Du GZ. 2009. Effect of phylogeny, life history and habitat correlates on seed germination of 69 arid and semi-arid zone species from northwest China. Evolutionary Ecology 23: 827-846.

Wang JH, Wen C, Baskin CC, Baskin JM, Cui XL, Zhang Y, Qiang WY, Du GZ. 2012. Variation in seed germination of 86 subalpine forest species from the eastern Tibetan Plateau: phylogeny and life-history correlates. Ecological Research 27: 453-465. Zago de Andrade LA, Miranda HHS. 2014. The dynamics of the soil seed bank after a fire event in a woody savanna in central Brazil. Plant Ecology 215: 1199-1209.

Zimmermann J, Higgins SI, Grimm V, Hoffmann J, Münkemüller T, Linstädter A. 2008. Recruitment filters in a perennial grassland: the interactive roles of fire, competitors, moisture and seed availability. Journal of Ecology 96: 1033-1044. 
546 Zuur AF, Ieno EN, Walker NJ, Saveliev AA, Smith GM. 2009. Mixed effects models

547 an extensions in ecology with $R$. Springer, New York, US. 
Table 1. Time of seed dispersal, seed dispersal syndrome and habitat of occurrence of grass species from open savannas and wet grasslands of Central Brazil.

\begin{tabular}{|c|c|c|c|c|}
\hline Species & $\begin{array}{l}\text { Seed dispersal } \\
\text { syndrome }\end{array}$ & $\begin{array}{l}\text { Seed dispersal } \\
\quad(\text { Season })\end{array}$ & Habitat & Site \\
\hline $\begin{array}{l}\text { Agenium goyazense } \\
\text { (Hack.) Clayton }\end{array}$ & Barochory & Dry & $\begin{array}{c}\text { Open } \\
\text { savanna }\end{array}$ & PNB \\
\hline $\begin{array}{l}\text { Andropogon } \\
\text { leucostachyus Kunth }\end{array}$ & Anemochory & Early & $\begin{array}{c}\text { Wet } \\
\text { grassland }\end{array}$ & FAL \\
\hline $\begin{array}{l}\text { Anthaenantia lanata } \\
\text { (Kunth) Benth. }\end{array}$ & Anemochory & Early & $\begin{array}{c}\text { Open } \\
\text { savanna }\end{array}$ & PNB \\
\hline $\begin{array}{l}\text { Aristida gibbosa (Nees) } \\
\text { Kunth }\end{array}$ & Barochory & Dry & $\begin{array}{c}\text { Open } \\
\text { savanna }\end{array}$ & FAL \\
\hline Aristida recurvata Kunth & Barochory & Dry & $\begin{array}{c}\text { Open } \\
\text { savanna }\end{array}$ & PNB \\
\hline Aristida riparia Trin. & Barochory & Dry & $\begin{array}{c}\text { Open } \\
\text { savanna }\end{array}$ & FAL \\
\hline Aristida setifolia Kunth & Barochory & Late & $\begin{array}{c}\text { Open } \\
\text { savanna }\end{array}$ & FAL \\
\hline $\begin{array}{l}\text { Arthropogon villosus } \\
\text { Nees }\end{array}$ & Barochory & Early & $\begin{array}{c}\text { Wet } \\
\text { grassland }\end{array}$ & PNB \\
\hline $\begin{array}{l}\text { Axonopus siccus var. } \\
\text { siccus (Nees) Kuhlm. }\end{array}$ & Barochory & Late & $\begin{array}{c}\text { Open } \\
\text { savanna }\end{array}$ & FAL \\
\hline $\begin{array}{l}\text { Ctenium cirrhosum } \\
\text { (Nees) Kunth }\end{array}$ & Anemochory & Late & $\begin{array}{c}\text { Open } \\
\text { savanna }\end{array}$ & PNB \\
\hline $\begin{array}{l}\text { Digitaria lehmanniana } \\
\text { Henrard }\end{array}$ & Barochory & Late & $\begin{array}{c}\text { Wet } \\
\text { grassland }\end{array}$ & PNB \\
\hline $\begin{array}{l}\text { Echinolaena inflexa } \\
\text { (Poir.) Chase }\end{array}$ & Barochory & Late & $\begin{array}{c}\text { Open } \\
\text { savanna }\end{array}$ & FAL \\
\hline $\begin{array}{l}\text { Elionurus muticus } \\
\text { (Spreng.) Kuntze }\end{array}$ & Anemochory & Early & $\begin{array}{c}\text { Open } \\
\text { savanna }\end{array}$ & PNB \\
\hline $\begin{array}{l}\text { Eragrostis polytricha } \\
\text { Nees }\end{array}$ & Barochory & Early & $\begin{array}{c}\text { Wet } \\
\text { grassland }\end{array}$ & PNB \\
\hline $\begin{array}{l}\text { Homolepis longispicula } \\
\text { (Döll) Chase }\end{array}$ & Anemochory & Early & $\begin{array}{c}\text { Wet } \\
\text { grassland }\end{array}$ & PNB \\
\hline $\begin{array}{l}\text { Ichnanthus camporum } \\
\text { Swallen }\end{array}$ & Barochory & Late & $\begin{array}{c}\text { Open } \\
\text { savanna }\end{array}$ & FAL \\
\hline
\end{tabular}


Mesosetum ferrugineum

Anemochory

Early

Wet

PNB

(Trin.) Chase

grassland

Panicum olyroides Barochory

Early

Open

PNB

Kunth

savanna

Paspalum carinatum Anemochory

Late

Open

FAL

Humb. \& Bonpl. ex

savanna

Flüggé

Paspalum erianthum Anemochory

Nees ex. Trin.

Early

Open

PNB

savanna

Paspalum glaucescens Barochory

Late

Open

PNB

Hack.

Paspalum guttatum Trin. Anemochory

Early

savanna

Open

PNB

savanna

Paspalum maculosum Barochory

Late

Wet

PNB

Trin.

grassland

Paspalum pectinatum Anemochory

Nees ex Trin.

Early

Open

PNB

Paspalum polyphyllum Anemochory

Dry

savanna

Nees

Wet

FAL grassland

Saccharum villosum Anemochory

Early

Wet

PNB

Steud.

grassland

Sacciolepis myurus Barochory

Dry

Wet

FAL

(Lam.) Chase

Schizachyrium

sanguineum

(Retz.)

Barochory

Dry

grassland

Alston

Setaria parviflora (Poir.) Barochory

Late

Open

PNB

Kerguélen

Time period of seed dispersal: Early (October - January), late in the rainy season (February - April) and during the dry season (May - September). Site of occurrence: PNB (National Park of Brasília) and FAL (Água Limpa farm). G = Germination; V = Viability; GV = Germination proportion of viable seeds. 
Table 2. Multiple comparisons of differences in soil water potential between open savannas and wet grasslands from Central Brazil during the dry season months.

\begin{tabular}{ccccccc}
\hline Month & LRT $_{1}$ & $\mathrm{P}$ & Habitat & Depth $(\mathrm{cm})$ & $\beta \pm \mathrm{SE}$ & $\mathrm{P}$ \\
\hline June & 17.562 & $\mathrm{P}<0.001$ & $\mathrm{OS}-\mathrm{WG}=0$ & $2-3$ & $0.6346 \pm 0.2192$ & $\mathrm{P}<0.05$ \\
& & & $\mathrm{OS}-\mathrm{WG}=0$ & $10-11$ & $0.4418 \pm 0.2189$ & $\mathrm{P}=0.05$ \\
\multirow{5}{*}{ July } & \multirow{2}{*}{21.405} & $\mathrm{P}<0.001$ & $\mathrm{OS}-\mathrm{WG}=0$ & $2-3$ & $0.6161 \pm 0.2334$ & $\mathrm{P}<0.05$ \\
& & & $\mathrm{OS}-\mathrm{WG}=0$ & $10-11$ & $0.4293 \pm 0.2328$ & $\mathrm{P}=0.08$ \\
\multirow{5}{*}{ August } & \multirow{2}{*}{39.049} & $\mathrm{P}<0.001$ & $\mathrm{OS}-\mathrm{WG}=0$ & $2-3$ & $0.9121 \pm 0.2199$ & $\mathrm{P}<0.05$ \\
& & & $\mathrm{OS}-\mathrm{WG}=0$ & $10-11$ & $0.6127 \pm 0.2194$ & $\mathrm{P}<0.05$ \\
\hline
\end{tabular}

$\mathrm{OS}=$ Open Savannas, $\mathrm{WG}=$ Wet Grasslands. $\beta \pm$ Standard Error. 
Table 3. Seed germination and viability of grass species from Cerrado according to dispersal time, seed dispersal syndrome and habitat of seed collection along twelve months of dry storage.

\section{Dry storage (Months)}
0
3
6
9
12

\begin{tabular}{|c|c|c|c|c|c|}
\hline \multicolumn{6}{|l|}{ SEED VIABILITY $(\%)$} \\
\hline \multicolumn{6}{|l|}{ Dispersal time } \\
\hline Early & $73.8 \pm 2.8$ & $69.9 \pm 3.4$ & $65.0 \pm 4.0$ & $76.3 \pm 3.4$ & $50.0 \pm 4.7$ \\
\hline Late & $70.3 \pm 3.7$ & $68.7 \pm 4.2$ & $63.9 \pm 3.7$ & $57.6 \pm 4.3$ & $52.1 \pm 4.6$ \\
\hline Dry & $72.7 \pm 3.9$ & $81.4 \pm 2.0$ & $77.4 \pm 3.0$ & $66.8 \pm 4.8$ & $81.5 \pm 5.7$ \\
\hline \multicolumn{6}{|l|}{ Habitat } \\
\hline Open savanna & $72.4 \pm 2.4$ & $69.8 \pm 2.7$ & $63.1 \pm 2.93$ & $62.6 \pm 3.33$ & $46.7 \pm 4.21$ \\
\hline Wet grassland & $72.1 \pm 3.5$ & $78.2 \pm 2.7$ & $76.3 \pm 2.98$ & $76.1 \pm 3.05$ & $63.7 \pm 4.56$ \\
\hline \multicolumn{6}{|l|}{ Seed dispersal } \\
\hline Anemochoric seeds & $71.1 \pm 2.8$ & $67.2 \pm 3.5$ & $67.7 \pm 3.8$ & $66.7 \pm 4.2$ & $44.5 \pm 4.7$ \\
\hline Barochoric seeds & $73.1 \pm 2.6$ & $77.4 \pm 2.1$ & $67.6 \pm 2.8$ & $68.2 \pm 2.9$ & $61.3 \pm 4.1$ \\
\hline \multicolumn{6}{|c|}{ SEED GERMINATION $(\%)$} \\
\hline \multicolumn{6}{|c|}{ Dispersal time } \\
\hline Early & $59.8 \pm 4.3$ & $59.7 \pm 4.5$ & $60.0 \pm 4.5$ & $68.3 \pm 4.2$ & $43.7 \pm 4.8$ \\
\hline Late & $7.6 \pm 2.0$ & $18.5 \pm 4.0$ & $23.9 \pm 4.8$ & $29.5 \pm 4.9$ & $26 \pm 4.4$ \\
\hline Dry & $33.6 \pm 6.1$ & $43.6 \pm 6.0$ & $54.3 \pm 4.9$ & $38.0 \pm 4.7$ & $59.5 \pm 5.2$ \\
\hline \multicolumn{6}{|l|}{ Habitat } \\
\hline Open savanna & $30.3 \pm 3.6$ & $40.1 \pm 3.8$ & $38.6 \pm 3.6$ & $40.2 \pm 3.8$ & $27.5 \pm 3.8$ \\
\hline Wet grassland & $45.2 \pm 5.4$ & $48.0 \pm 5.8$ & $60.6 \pm 5.1$ & $62.1 \pm 5.0$ & $54.9 \pm 5.0$ \\
\hline \multicolumn{6}{|l|}{ Dispersal syndrome } \\
\hline Anemochoric seeds & $59.8 \pm 3.9$ & $63.3 \pm 3.7$ & $61.4 \pm 4.5$ & $65.6 \pm 4.4$ & $43.8 \pm 4.7$ \\
\hline Barochoric seeds & $20.6 \pm 3.5$ & $29.5 \pm 4.1$ & $36.9 \pm 3.8$ & $36.4 \pm 3.9$ & $34.4 \pm 4.5$ \\
\hline \multicolumn{6}{|l|}{ SAMPLE SIZE (N) } \\
\hline \multicolumn{6}{|l|}{ Dispersal time } \\
\hline Early & $60 ; 12$ & $45 ; 9$ & $60 ; 12$ & $60 ; 12$ & $60 ; 12$ \\
\hline Late & $50 ; 10$ & $30 ; 6$ & $50 ; 10$ & $50 ; 10$ & $40 ; 8$ \\
\hline Dry & $35 ; 7$ & $35 ; 7$ & $35 ; 7$ & $25 ; 5$ & $10 ; 2$ \\
\hline \multicolumn{6}{|l|}{ Habitat } \\
\hline Open savanna & $95 ; 19$ & $65 ; 13$ & $95 ; 19$ & $85 ; 17$ & $65 ; 13$ \\
\hline Wet grassland & $50 ; 10$ & $45 ; 9$ & $50 ; 10$ & $50 ; 10$ & $45 ; 9$ \\
\hline \multicolumn{6}{|l|}{ Seed dispersal } \\
\hline Anemochoric seeds & $55 ; 11$ & $45 ; 9$ & $55 ; 11$ & $55 ; 11$ & $50 ; 10$ \\
\hline Barochoric seeds & $90 ; 18$ & $65 ; 13$ & $90 ; 18$ & $80 ; 16$ & $60 ; 12$ \\
\hline
\end{tabular}

Mean \pm Standard Error. Sample size $=$ Number of petri dishes; Number of species. 551 


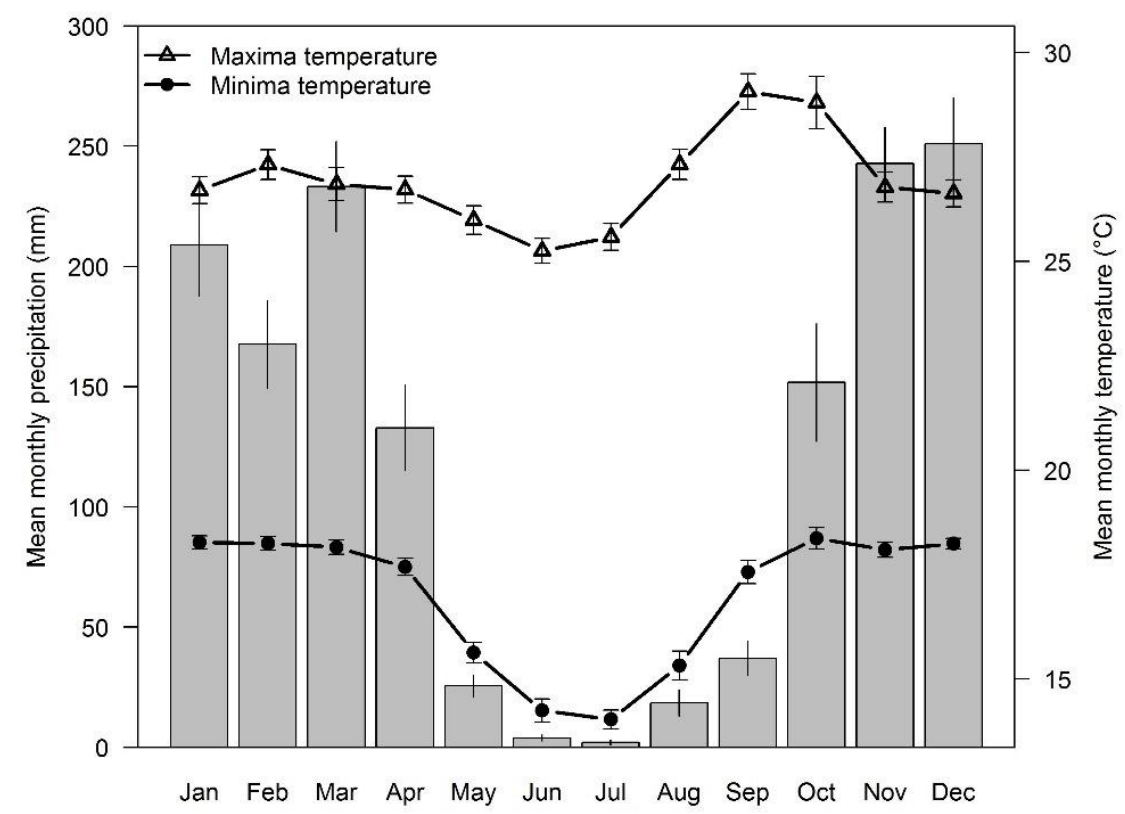

552

553 Figure 1. Mean monthly minimum and maximum temperatures and precipitation in 554 Brasília-DF from 1994 to 2014. Data from BDMEP/INMET. 


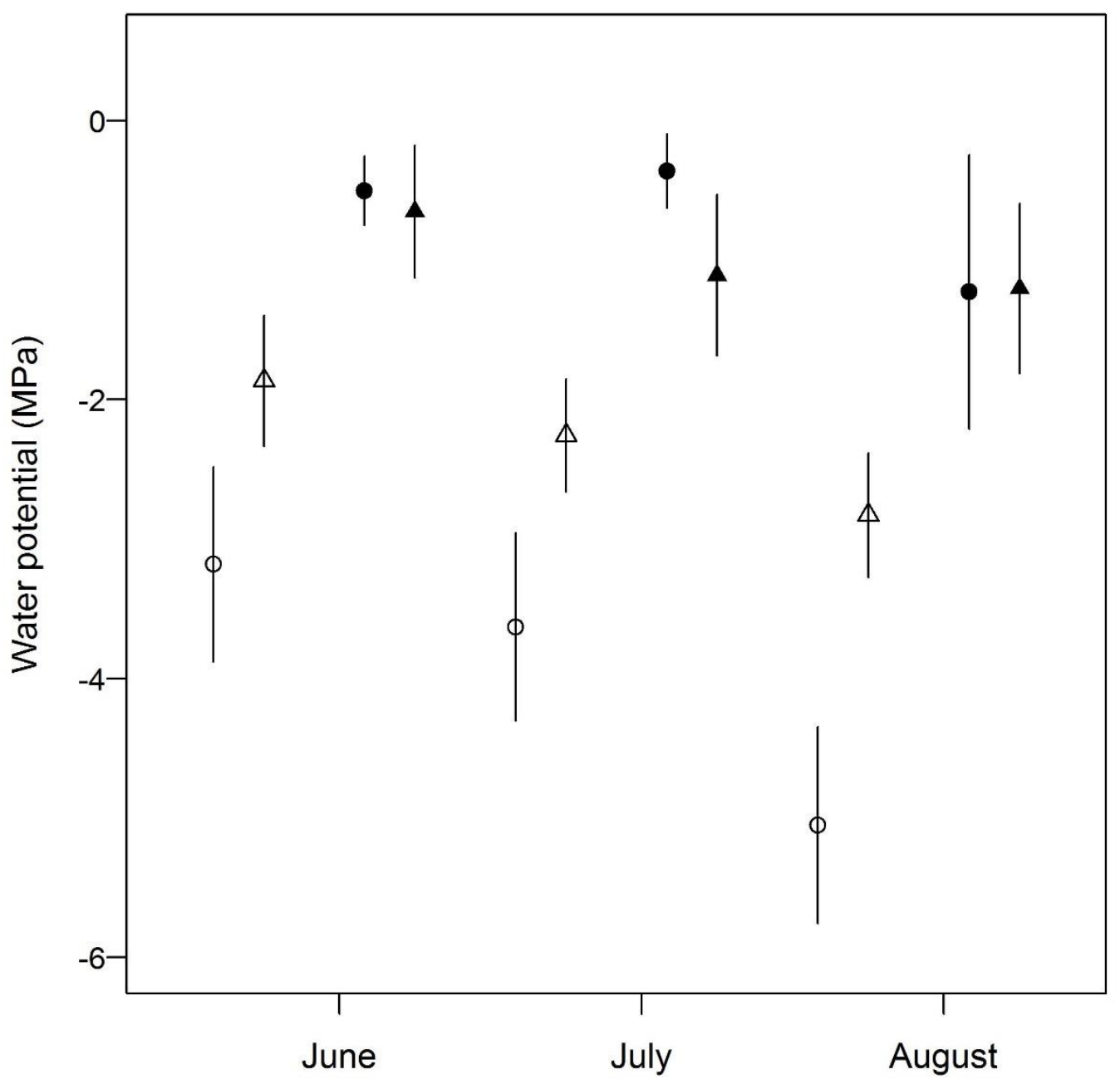

555

556 Figure 2. Soil water potential (MPa) of wet grasslands and open savannas during the dry 557 season. Open symbols $=$ open savannas; Closed symbols $=$ wet grasslands; Circles $=2$ $5583 \mathrm{~cm}$ depth; Triangles $=10-11 \mathrm{~cm}$ depth. Mean $+95 \%$ Confidence Interval. 


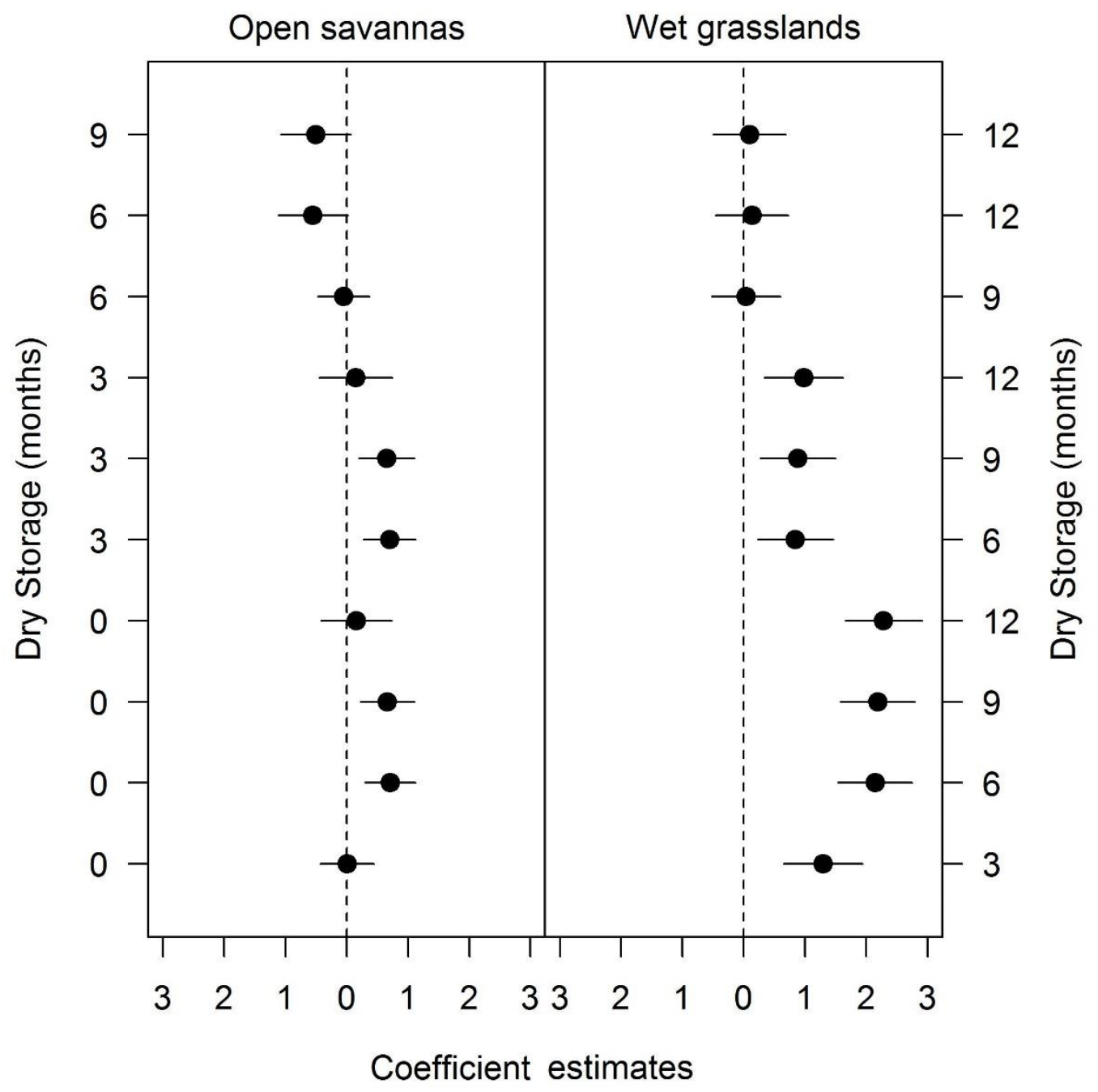

560 Figure 3. Coefficient estimates from pairwise multiple comparisons of germination 561 probability between months of dry storage in grass species from open savannas and wet 562 grasslands. The closed circles denote the mean values, the error bars denote $95 \%$ of 563 lower and upper confidence intervals. The central dotted line (zero value) means no 564 statistical difference. 


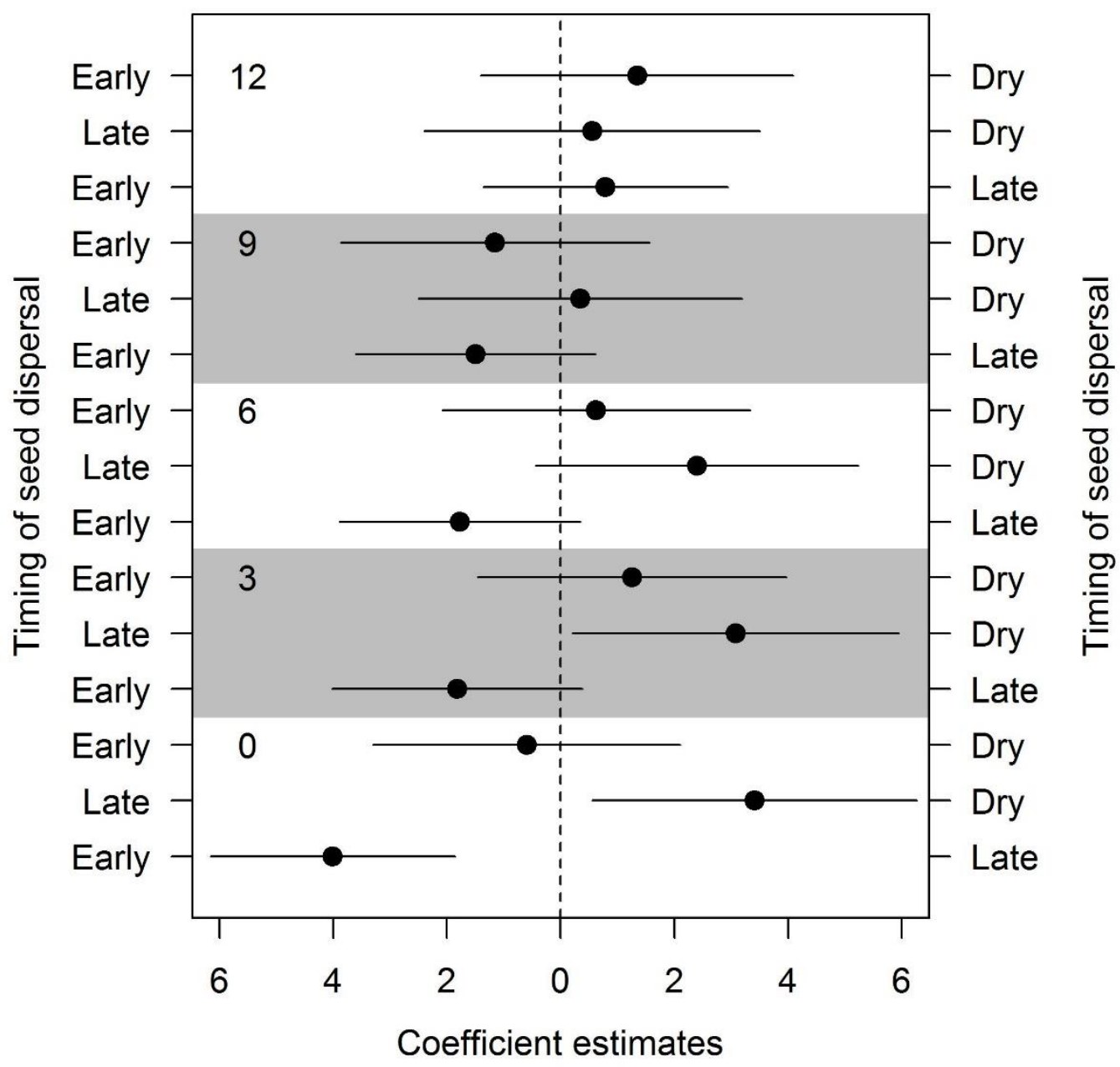

565

566 Figure 4. Coefficient estimates from pairwise multiple comparisons of germination

567 probability between grass seeds dispersed early, late in the rainy season and in the dry

568 season along dry storage ( $0,3,6,9$ and 12 months). The closed circles denote the mean

569 values, the error bars denote $95 \%$ of lower and upper confidence intervals. The central

570 dotted line (zero value) means no statistical difference. 


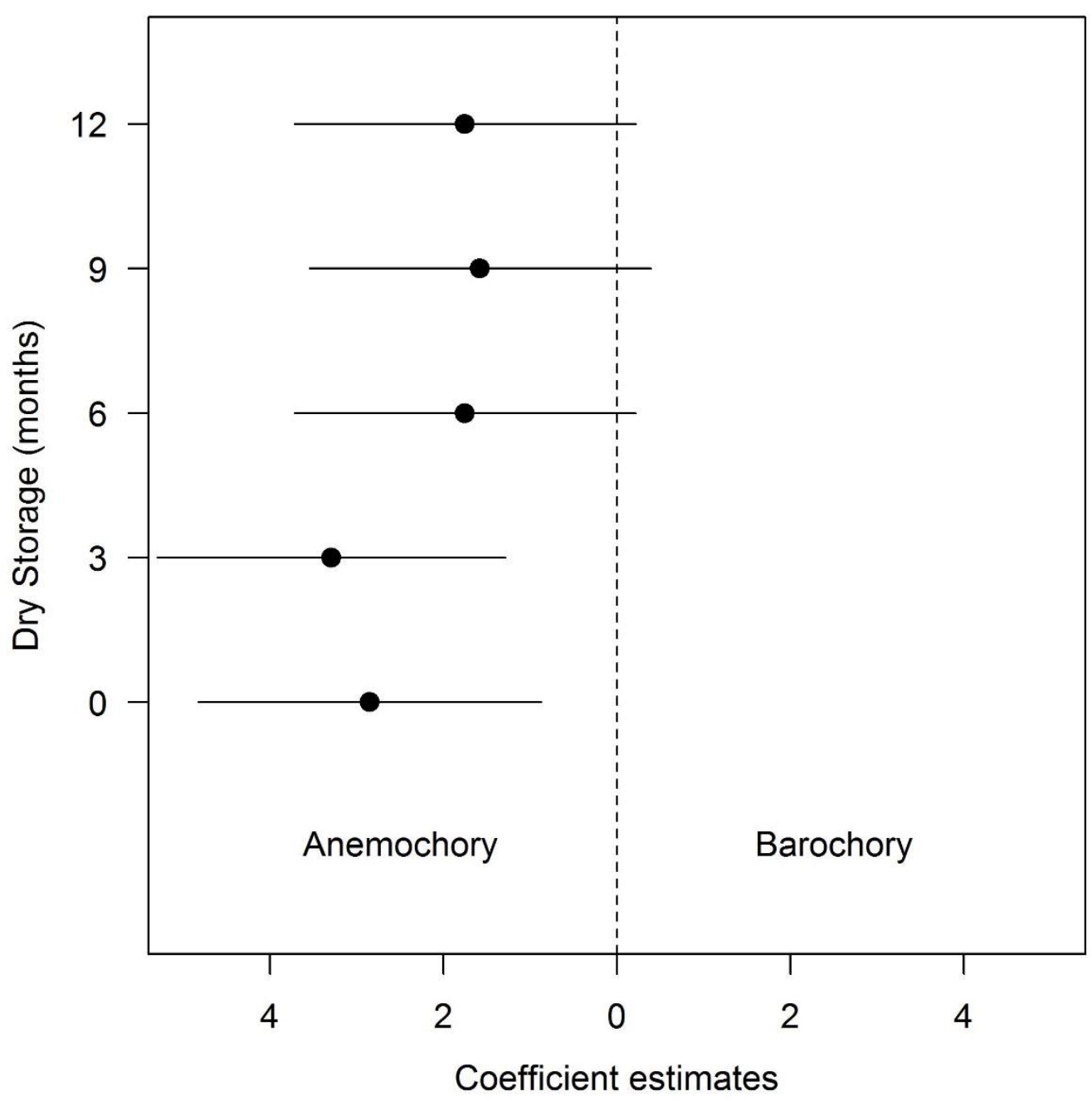

571

572

573 Figure 5. Coefficient estimates from pairwise multiple comparisons of germination

574 probability between grass species with anemochory and barochory dispersal syndromes

575 along dry storage (0, 3, 6, 9 and 12 months). The closed circles denote the mean values,

576 the error bars denote $95 \%$ of lower and upper confidence intervals. The central dotted

577 line (zero value) means no statistical difference. 


\section{SUPPLEMENTARY DATA}

Table S1. Post-hoc comparisons of probability of seed viability between dry storage months according to habitat types. Significant differences in bold.

\begin{tabular}{lcccc}
\hline & Open savanna & & & \\
Dry storage (months) & $\beta$ & $\mathrm{SE}$ & $\mathrm{Z}$ & $\mathrm{P}$ \\
$12-9$ & -0.17 & 0.25 & -0.69 & 0.96 \\
$12-6$ & -0.32 & 0.25 & -1.29 & 0.69 \\
$12-3$ & -0.24 & 0.26 & -0.93 & 0.88 \\
$12-0$ & -0.75 & 0.25 & -3.05 & $\mathbf{0 . 0 2}$ \\
$9-6$ & -0.14 & 0.18 & -0.78 & 0.93 \\
$9-3$ & -0.07 & 0.20 & -0.34 & 1.00 \\
$9-0$ & -0.58 & 0.19 & -3.13 & $\mathbf{0 . 0 1}$ \\
$6-3$ & 0.08 & 0.19 & 0.40 & 0.99 \\
$6-0$ & -0.44 & 0.18 & -2.48 & 0.09 \\
$3-0$ & -0.51 & 0.19 & -2.69 & 0.05 \\
\hline & Wet grassland & & & \\
Dry storage (months) & $\beta$ & $\mathrm{SE}$ & $\mathrm{Z}$ & $\mathrm{P}$ \\
$12-9$ & -0.26 & 0.25 & -1.03 & 0.84 \\
$12-6$ & -0.49 & 0.25 & -1.97 & 0.28 \\
$12-3$ & -0.63 & 0.26 & -2.39 & 0.12 \\
$12-0$ & -0.22 & 0.25 & -0.87 & 0.91 \\
$9-6$ & -0.23 & 0.24 & -0.96 & 0.87 \\
$9-3$ & -0.37 & 0.25 & -1.45 & 0.59 \\
$9-0$ & 0.04 & 0.24 & 0.18 & 1.00 \\
$6-3$ & -0.14 & 0.25 & -0.54 & 0.98 \\
$6-0$ & 0.27 & 0.24 & 1.15 & 0.78 \\
$3-0$ & 0.41 & 0.25 & 1.64 & 0.47 \\
\hline
\end{tabular}




\begin{tabular}{lcccc}
\hline \multicolumn{5}{c}{ Table S2. Post-hoc comparisons of probability of seed viability between seeds with } \\
contrasting dispersal syndromes across dry storage months. Significant differences in bold. \\
\hline \multicolumn{5}{c}{ Barochory - Anemochory $=0$} \\
Dry storage (months) & $\beta$ & $\mathrm{SE}$ & $\mathrm{Z}$ & $\mathrm{P}$ \\
0 & -0.31 & 0.33 & -0.93 & 0.35 \\
3 & -0.18 & 0.41 & -0.47 & 0.65 \\
6 & -0.80 & 0.33 & -2.38 & $\mathbf{0 . 0 2}$ \\
9 & 0.22 & 0.34 & 0.66 & 0.51 \\
12 & 0.43 & 0.36 & 1.22 & 0.22 \\
\hline
\end{tabular}




\begin{tabular}{|c|c|c|c|c|}
\hline \multicolumn{5}{|c|}{$\begin{array}{l}\text { Table S3. Post-hoc comparisons of probability of seed viability between dry storage months } \\
\text { according to the timing of seed dispersal. Significant differences in bold. }\end{array}$} \\
\hline \multicolumn{5}{|c|}{ Dry season } \\
\hline Dry storage (months) & $\beta$ & SE & Z & $\mathrm{P}$ \\
\hline $12-9$ & 1.31 & 0.47 & 2.78 & 0.04 \\
\hline $12-6$ & 0.54 & 0.46 & 1.16 & 0.77 \\
\hline $12-3$ & 0.44 & 0.47 & 0.94 & 0.88 \\
\hline $12-0$ & 1.05 & 0.46 & 2.26 & 0.15 \\
\hline $9-6$ & -0.78 & 0.32 & -2.45 & 0.10 \\
\hline $9-3$ & -0.87 & 0.33 & -2.64 & 0.06 \\
\hline $9-0$ & -0.27 & 0.32 & -0.84 & 0.92 \\
\hline $6-3$ & -0.09 & 0.31 & -0.31 & 1.00 \\
\hline $6-0$ & 0.51 & 0.29 & 1.75 & 0.40 \\
\hline $3-0$ & 0.60 & 0.31 & 1.97 & 0.27 \\
\hline \multicolumn{5}{|c|}{ Early rainy season } \\
\hline Dry storage (months) & $\beta$ & SE & $\mathrm{Z}$ & $\mathrm{P}$ \\
\hline $12-9$ & -1.75 & 0.22 & -7.90 & $<0.001$ \\
\hline $12-6$ & -0.85 & 0.21 & -4.00 & $<0.001$ \\
\hline $12-3$ & -1.15 & 0.25 & -4.57 & $<0.001$ \\
\hline $12-0$ & -1.42 & 0.22 & -6.58 & $<0.001$ \\
\hline $9-6$ & 0.89 & 0.22 & 4.07 & $<0.001$ \\
\hline $9-3$ & 0.60 & 0.25 & 2.37 & 0.12 \\
\hline $9-0$ & 0.33 & 0.22 & 1.51 & 0.55 \\
\hline $6-3$ & -0.29 & 0.25 & -1.17 & 0.77 \\
\hline $6-0$ & -0.56 & 0.21 & -2.64 & 0.06 \\
\hline $3-0$ & -0.27 & 0.25 & -1.09 & 0.81 \\
\hline \multicolumn{5}{|c|}{ Late rainy season } \\
\hline Dry storage (months) & $\beta$ & SE & $\mathrm{Z}$ & $\mathrm{P}$ \\
\hline $12-9$ & -0.21 & 0.29 & -0.74 & 0.95 \\
\hline $12-6$ & -0.89 & 0.28 & -3.14 & 0.01 \\
\hline $12-3$ & -0.60 & 0.33 & -1.79 & 0.38 \\
\hline $12-0$ & -1.09 & 0.29 & -3.77 & $<0.01$ \\
\hline $9-6$ & -0.68 & 0.26 & -2.67 & 0.06 \\
\hline $9-3$ & -0.38 & 0.30 & -1.29 & 0.70 \\
\hline $9-0$ & -0.87 & 0.26 & -3.40 & 0.01 \\
\hline $6-3$ & 0.30 & 0.30 & 0.99 & 0.86 \\
\hline $6-0$ & -0.19 & 0.26 & -0.75 & 0.94 \\
\hline $3-0$ & -0.49 & 0.30 & -1.63 & 0.48 \\
\hline
\end{tabular}




\begin{tabular}{|c|c|c|c|c|}
\hline \multicolumn{5}{|c|}{$\begin{array}{l}\text { Table S4. Post-hoc comparisons of probability of seed viab } \\
\text { different periods across dry storage months. Significant diffe } \\
\text { Dry storage }=0 \text { month }\end{array}$} \\
\hline Timing of seed dispersal & $\beta$ & SE & $\mathrm{Z}$ & $\mathrm{P}$ \\
\hline Early x Late & -0.59 & 0.36 & -1.65 & 0.22 \\
\hline Early x Dry & 0.25 & 0.42 & 0.59 & 0.83 \\
\hline Late x Dry & 0.84 & 0.38 & 2.20 & 0.07 \\
\hline \multicolumn{5}{|c|}{ Dry storage $=3$ months } \\
\hline Timing of seed dispersal & $\beta$ & SE & $\mathrm{Z}$ & $\mathrm{P}$ \\
\hline Early x Late & -0.38 & 0.45 & -0.83 & 0.68 \\
\hline Early x Dry & -0.63 & 0.46 & -1.35 & 0.37 \\
\hline Late x Dry & -0.25 & 0.40 & -0.63 & 0.81 \\
\hline \multicolumn{5}{|c|}{ Dry storage $=6$ months } \\
\hline Timing of seed dispersal & $\beta$ & SE & $\mathrm{Z}$ & $\mathrm{P}$ \\
\hline Early x Late & -0.96 & 0.36 & -2.68 & 0.02 \\
\hline Early x Dry & -0.83 & 0.42 & -1.97 & 0.12 \\
\hline Late x Dry & 0.14 & 0.38 & 0.36 & 0.93 \\
\hline \multicolumn{5}{|c|}{ Dry storage $=9$ months } \\
\hline Timing of seed dispersal & $\beta$ & SE & $\mathrm{Z}$ & $\mathrm{P}$ \\
\hline Early x Late & 0.61 & 0.36 & 1.68 & 0.21 \\
\hline Early x Dry & 0.85 & 0.44 & 1.92 & 0.13 \\
\hline Late x Dry & 0.23 & 0.41 & 0.57 & 0.84 \\
\hline \multicolumn{5}{|c|}{ Dry storage $=12$ months } \\
\hline Timing of seed dispersal & $\beta$ & SE & $\mathrm{Z}$ & $\mathrm{P}$ \\
\hline Early x Late & -0.93 & 0.39 & -2.39 & 0.04 \\
\hline Early x Dry & -2.22 & 0.54 & -4.11 & $<0.001$ \\
\hline Late x Dry & -1.29 & 0.58 & -2.23 & 0.06 \\
\hline
\end{tabular}


CAPÍTULO 2

Seed tolerance to heating is better predicted by seed dormancy than by habitat type in Neotropical savanna grasses 
1 Seed tolerance to heating is better predicted by seed dormancy than by habitat type in

2 Neotropical savanna grasses

3 Desirée M. Ramos ${ }^{1,5}$; Ana B. S. Liaffa ${ }^{2}$; Pedro Diniz ${ }^{3}$; Cássia B. R. Munhoz ${ }^{1}$; Mark K.

4 J. Ooi ${ }^{4,5}$; Fabian Borghetti ${ }^{1}$ and José F. M. Valls ${ }^{1,6}$

51 - Department of Botany - University of Brasília/Brazil; 2 - Department of Forest

6 Engineering - University of Brasília/Brazil; 3 - Department of Ecology - University of

7 Brasília; 4 - Centre for Sustainable Ecosystem Solutions, School of Biological Sciences

8 - University of Wollongong/Australia; 5 - Centre for Ecosystem Science, School of

9 Biological, Earth and Environmental Sciences, University of New South

10 Wales/Australia; 6 - Brazilian Corporation of Agricultural Research/Embrapa,

11 Brasília/Brazil.

12 Running head: Seed tolerance to heating in savanna grasses

13 Correspondence:

14 D. M. Ramos, Embrapa Recursos Genéticos e Biotecnologia. Parque Estação Biológica

15 PqEB, s/no. Caixa Postal 02372, P.O Box: 70770-900. Brasília, Distrito Federal, Brazil.

16 E-mail: desibio@gmail.com 
Open savannas and wet grasslands occur under the same seasonal macro-climate in central Brazil. However, in open savannas temperatures during fires are higher than in wet grasslands. Grasses dominate both ecosystems and exhibit large variation in seed dormancy. We hypothesize that seeds of species from open savannas are more tolerant to heating than those of wet grasslands. Assuming that dormant seeds might remain longer in the soil than non-dormant seeds, thus being more likely to burn, we expect that dormant seeds are more tolerant to heating than non-dormant seeds. We tested the effects of heating at 80 and $110^{\circ} \mathrm{C}$ for 2.5 and $5.0 \mathrm{~min}$ on the survival of seeds of 14 species, seven from each community, containing dormant and non-dormant species. Seeds of most species survived at $80^{\circ} \mathrm{C}$, but seeds from open savannas maintained greater survival for 5 min than seeds from wet grasslands. Seeds of most species died at $110^{\circ} \mathrm{C}$, but dormant seeds survived more than non-dormant seeds. We conclude that species with seed dormancy experience selection for covarying characteristics that allow tolerance to heating in hotter fires. Our findings suggest that both latency to germinate and habitat-specific fire temperatures may drive the evolution of seed fire tolerance in Neotropical savannas.

34 Additional Keywords: Heat shock, dormancy, fire, habitat seasonality, open savanna, wet grassland.

Summary: We investigated whether seed tolerance of high temperatures was related to dormancy or habitat type for grass species from Brazilian fire-prone savannas. Seeds from wetter habitats had lower tolerance while dormant seeds had high tolerance, suggesting both dormancy and habitat moisture drive the evolution of seed tolerance to heat. 


\section{Introduction}

Savannas are ecosystems characterized by a continuous herbaceous-grass layer, with a large representation of grasses, and a discontinuous distribution of shrubs and trees (Eiten 1972; Eiten 1978; Bourlière and Hadley 1983). Savannas are environments with a strongly seasonal climate, with two well defined seasons during the year, alternating between a rainy summer and a dry winter (Medina 1982; Sarmiento 1984). Consequently, the grass layer dries out during the dry season, becoming a highly flammable fuel for subsequent fires (Kauffman et al. 1994; Mistry 1998). Brazilian savannas and grasslands are known for their high propensity of fire occurrence (Kauffman et al. 1994; Mistry 1998; Miranda et al. 2010; Hoffmann et al. 2012), which is likely to have contributed to the evolution of seed tolerance to heating in several plant species (Ribeiro et al. 2012; Ribeiro and Borghetti 2013).

Seed survival to heating is considered an adaptation to fire in several taxa of plants from fire-prone environments (Overbeck et al. 2006). Nevertheless, there is considerable variability in seed survival after heat shock between species inhabiting fire-prone environments (Gashaw and Michelsen 2002; Overbeck et al. 2006; Paula and Pausas 2008; Ribeiro and Borghetti 2013; Ooi et al. 2014). The probability of seeds being burnt and the associated life-history cost to adult plants may be relevant mechanisms driving the evolution of seed tolerance to fire. For instance, previous studies have shown that seed tolerance to heat shock is negatively related to adult plant survival after fire in Mediterranean and Australian fire-prone environments (Paula and Pausas 2008; Ooi et al. 2014), and positively related to the probability of being exposure to burnt (e.g. when comparing habitats with different fire regimes in Australia and central Brazil) (Thomas et al. 2003; Ribeiro et al. 2012; Ribeiro and Borghetti 2013).

Seed dormancy is a mechanism to prevent germination in an unfavorable time for seedling growth and recruitment (Baskin and Baskin 2014). In general, seeds of grass species 
from savannas can either be non-dormant or physiologically dormant (Baskin and Baskin 2004; Aires et al. 2013; Baskin and Baskin 2014). As a consequence of seasonal climate, the reproductive period of herbaceous species in wet grasslands and open savannas in Brazil, including the production and dispersal of seeds, occurs mainly in the rainy season (Tannus et al. 2006; Munhoz and Felfili 2007b; Ramos et al. 2014). Therefore, seed germination and seedling recruitment of dormant grass seeds are expected to occur only at the beginning of the following rainy season, while the non-dormant seeds can germinate in the same dispersal season (Mott 1978; Veenendaal et al. 1996). Considering that dormant seeds might remain longer in soil than non-dormant seeds, thus being more likely to burn, we could expect that dormant seeds are more tolerant to high temperatures than non-dormant seeds.

In general, grass seeds from fire-prone environments are thought to survive heating between 70 and $100^{\circ} \mathrm{C}$, but seeds from most species do not survive at higher temperatures, especially at prolonged exposure times (e.g. 5 minutes) (Gashaw and Michelsen 2002; Overbeck et al. 2006; Dayamba et al. 2008; Reyes and Trabaud 2009; Gonzalez and Ghermandi 2012). However, in these studies it is clear that seeds of some species survive at the high temperatures and exposure times tested. But, it remains unclear which plant traits drive the variation between grass species from the same environment in tolerance to survive at high temperatures $\left(>100^{\circ} \mathrm{C}\right)$.

The maximum temperatures reached during fires in the environment in which species occur is among the potential factors influencing the tolerance of their seeds to heat shock. Fire temperatures can be highly variable and is dependent on the fuel amount and humidity across all fire-prone ecosystems, including within savannas and grasslands (Miranda et al. 1993; Williams et al. 2003). Wet grasslands (known as campo úmido) and open savannas (known as campo sujo) are common vegetation types within Brazilian savannas and are susceptible to fire (Munhoz and Felfili 2007a,b; Cianciaruso and Batalha 2008; Schmidt 2011). The top of 
the water table is deep below the soil surface in open savannas (about 1.1-4 m) (Rossatto et al. 2012), leading soil and the herbaceous layer to dry out during the dry winter season. In contrast, the water table sits near the surface in wet grasslands (about 20-80 cm) (Cianciaruso and Batalha 2008; Meirelles et al. 2010), making the soil moist for most of the year (Cianciaruso and Batalha 2008; Fidelis et al. 2013).

In both vegetation types, dried leaves of living herbaceous plants or dead leaf litter from these plants are the main fuel source (Kauffman et al. 1994; Hoffmann et al. 2012). Wet grasslands generally produce lower aboveground $(1 \mathrm{~cm}$ high) maximum temperatures during fire occurrence than open savannas, ranging from 57 to $330^{\circ} \mathrm{C}$ (Schmidt 2011) compared to 288 to $350^{\circ} \mathrm{C}$ (Miranda et al. 1993), respectively. We therefore, could expect that seeds of species from open savannas are more tolerant to heating at high temperatures than those of wet grasslands.

In this study, we use 14 perennial grass species (Poaceae) from either wet grasslands or open savannas of Central Brazil, to examine whether seed tolerance to fire can be explained by habitat type (opens savannas versus wet grasslands) and/or by seed dormancy status (non-dormant versus dormant). We predict that grass species occurring in wet grasslands, which burns less intensely than open savannas, produce seeds less tolerant to heat shock (simulating fire-generated temperatures) than seeds of open savannas grass species. We also predict that seeds of dormant species will be more tolerant to heating than seeds of nondormant species.

\section{Materials and Methods}

\section{Study area and seed collection}

Mature seeds of 14 native perennial grass species from Brazilian wet grasslands and open savannas were harvested manually from January/2012 to June/2013, in two areas of 
Brasília, Federal District: Fazenda Água Limpa - FAL (Água Limpa farm, University of Brasília- $15^{\circ} 58^{\prime} 43.06 " S$ and 4756'21.41"W, $1.197 \mathrm{~m}$ ) and the Parque Nacional de Brasília PNB (National Park of Brasília - 15³8'46.22"S and 4800'19.75"W, 1.178 m). All study species are closely related, from within the same clade (Grass Phylogeny Working Group II 2012), with 11 representatives of the tribe Paniceae. We monitored plants regularly, about weekly, to ensure that seeds were mature at the time of collection. We selected sites protected from cattle and with two different soil moisture conditions within these areas. The sites were either open savannas, an environment with strong seasonality, where the soils dry out during the dry season, or wet grasslands, a less seasonal environment, where the soils are moist for most of the year (Table 1). To ensure seeds were representative of a number of genotypes across the population, and since grasses have vegetative reproduction by rhizomes, we collected seeds from at least 30 individuals randomly selected across a large area of the habitat.

To ensure accurate identification we also collected voucher specimens of these species which were deposited at National Center of Genetic Resources - Cenargen/Embrapa herbarium (CEN). After collection caryopsis were stored in paper bags at laboratory at 20.6 and $26.6^{\circ} \mathrm{C}$ minimum and maximum temperatures, respectively, with storage times varying slightly dependent on ripening phenology (Table 1).

\section{Initial seed dormancy}

Based on germination trials conducted with fresh collected seeds (about one week after collection), we categorized species as either dormant or non-dormant (Table 1). For germination experiments we used five replicates of 20 seeds for each species, in an incubation chamber, with $12 \mathrm{~h}$ photoperiod with $28 / 18^{\circ} \mathrm{C}$ cycle at day/night, respectively. Temperatures vary little over the year in this climatic region $\left(\sim 3^{\circ} \mathrm{C}\right)$, and the experimental trials represents the mean maxima and minima temperatures during the wet summer, which is the main period 
of seed dispersal and growth of grasses in these environments. We recorded the germination daily for 30 days and used radicle emergence as the criterion for seed germination. After the germination experiments, we categorized species as dormant if more than $50 \%$ of the viable seed lot did not germinate (Table 1).

\section{Heat shock treatments}

Aiming to simulate the effects of a fire component (high temperatures) on seed survival, the following treatments were applied on the seed samples: $80^{\circ} \mathrm{C}$ for $2.5 \min (\mathrm{t} 1)$; $80^{\circ} \mathrm{C}$ for $5 \min (\mathrm{t} 2) ; 110^{\circ} \mathrm{C}$ for $2.5 \mathrm{~min}(\mathrm{t} 3) ; 110^{\circ} \mathrm{C}$ for $5 \min (\mathrm{t} 4)$. Unheated seeds were the controls. The temperatures and exposure times were chosen to simulate the conditions experienced at $1 \mathrm{~cm}$ aboveground in the soil in Brazilian wet grasslands and open savannas during prescribed fires (Miranda et al. 1993; Schmidt 2011). Although these studies registered their highest maximum temperatures above $80^{\circ} \mathrm{C}$ and $110^{\circ} \mathrm{C}$ (e.g. $330^{\circ} \mathrm{C}, \mathrm{Schmidt}$ $2011 ; 350^{\circ} \mathrm{C}$, Miranda et al. 1993 ), lower maximum temperatures of $56^{\circ} \mathrm{C}$ (Schmidt 2011) and $106^{\circ} \mathrm{C}$ (Marinho and Miranda 2013) were also commonly recorded. The exposure times of $2.5 \mathrm{~min}$ and $5 \mathrm{~min}$ were chosen because the residence times of higher temperatures (> $60^{\circ} \mathrm{C}$ ) range from $1 \mathrm{~min}$ to $4 \mathrm{~min}$ in wet grasslands (Schmidt 2011) and from $1.5 \mathrm{~min}$ to 4.5 min in open savannas (Miranda et al. 1993). The heat shock treatments were simulated in an oven with air circulation (Marconi - MA035/1). Four replications of 25 seeds were used per species, in each treatment, except for Homolepis longispicula, where only four replications of 10 seeds were possible due to limited seed numbers.

\section{Germination and viability}

The germination and viability of seeds were tested after the heat shock treatments ( $\mathrm{t} 1$, t2, t3, t4 and control). Seeds were placed on two sheets of 9-cm-diameter filter paper in petri dishes and moistened with distilled water. The germination trials were conducted in a 
germination chamber (Marconi/MA402), at a constant single temperature of $30{ }^{\circ} \mathrm{C}$ and 12 hours of dark/light photoperiod for comparative purposes between species and treatments. The germination was checked every 2 days for 15 days. We used the radicle emergence followed by its gravitropic curvature as a criterion of seed germination. After each germination trial the viability of non-germinated seeds were tested using $1 \%$ tetrazolium chloride solution. The seeds were placed in contact with tetrazolium solution for 24 hours in dark at $30^{\circ} \mathrm{C}$ in a germination chamber. We considered as viable the seeds that the embryos were dark pink or red. Germination and viability data were combined to calculate the total viable seeds remaining after heat treatments.

\section{Statistical analysis}

We analyzed all data with R 3.1.2 software (R Core Team 2014). First, we analyzed the effect of heat shock treatments on seed viability (presence/absence) with Generalized Linear Models (GLM, binomial error distribution), separately for each species. We included the heat shock treatments ( $\mathrm{t} 1, \mathrm{t} 2, \mathrm{t} 3, \mathrm{t} 4$ and control) as fixed independent variable. Seeds inside the petri dishes are under the same environment which can affect the germination pattern of neighbors'seeds (Tielbörger and Prasse 2009), resulting in autocorrelation of errors (Sileshi 2012). So, we used each seed as an experimental unity and the replication $(\mathrm{N}=4)$ as a

fixed independent variable, in order to control this autocorrelation of errors. We used likelihood ratio tests coupled with stepwise backward procedure to run the model selection. We made post-hoc multiple comparisons between control and heating treatments, using the single step method to P-values adjustment and the glht command of multcomp package (Hothorn et al. 2008).

We used Generalized Linear Mixed Models (GLMM, binomial distribution, see Zuur et al. 2009) (package: lme4; see Bates et al. 2014) to test whether the effect of heating treatments on seed viability is dependent of seed dormancy and habitat of seed collection. We 
included species and replication as nested random factors in all models. We first included seed viability (presence/absence) as the response variable and a three-way interaction between heat treatment (t1, t2, t3, $\mathrm{t} 4$ and control), habitat (open savannas or wet grasslands) and seed dormancy (Dormant or Non-dormant), as fixed independent variables. Then we checked for collinearity effects using the variance inflation factor (VIF), assuming accepted values with VIF $<10$ (Dormann et al. 2013). Because we found high values of VIF $(>10)$ in this first model, we built a second model without the three-way interaction. In this new model, we included two-way interactions between heating treatment ( $\mathrm{t} 1, \mathrm{t} 2, \mathrm{t} 3, \mathrm{t} 4$ and control) and habitat (Open savannas or Wet grasslands), and between heating treatment and seed dormancy (Dormant or Non-dormant). Finally, we carried out the same procedures of model selection and multiple comparisons described for the prior analysis.

\section{Results}

\section{Heat shock effects on seed viability}

With the exception of Anthaenanthia lanata, Saccharum villosum, Digitaria

lehmanniana and Homolepis longispicula, seeds of all species maintained high seed viability after being exposed to $80^{\circ} \mathrm{C}$, irrespective of the exposure time (Fig. 1). However, there was a clear negative effect on their viability when the seeds were exposed to $110^{\circ} \mathrm{C}$, for 2.5 and 5 minutes (Fig.1). With the exception of Aristida riparia, Aristida setifolia and Sacciolepis myurus, whose seeds kept high viability after being subjected to $110^{\circ} \mathrm{C}$, seeds of all species significantly lost viability after this heat shock, at both exposure times (Fig.1).

\section{Effects of dormancy status and habitat on seed viability after heat shock}

There was no difference in viability between controls of all multiple comparisons groups: non-dormant and dormant (Fig. 2), wet grasslands and open savannas (Fig. 3). So, there was no influence of initial viability (Fig. 2 and 3) and the following comparisons between all treatments ( $\mathrm{t} 1, \mathrm{t} 2, \mathrm{t} 3$ and $\mathrm{t} 4)$ were possible. The effect of heat shock treatments on 
seed viability was dependent on seed dormancy $\left(\mathrm{LRT}_{4}=246.14, P<0.0001\right)$. Although no differences were found between dormant and non-dormant seeds in respect to their response to heat shock of $80^{\circ} \mathrm{C}$ (Fig. 2), dormant seeds survived more than non-dormant seeds after exposure to $110^{\circ} \mathrm{C}$ (Fig. 2).

The effect of heat shock treatments on seed viability was dependent on habitat $\left(\mathrm{LRT}_{4}\right.$ $=44.99, P<0.0001)$. With exception of the treatment of $80^{\circ} \mathrm{C}$ for $5 \mathrm{~min}$, in which seeds from open savannas survived more than seeds from wet grasslands, no statistical differences were found in the viability of seeds collected in open savannas and wet grasslands (Fig. 3).

\section{Discussion}

Seeds of most grass species (10 out of 14) survived heat shock of $80^{\circ} \mathrm{C}$ for 2.5 and 5.0 min. This result was similar to that recorded for grass seeds in both African (Gashaw and Michelsen 2002) and Australian savannas (Clarke and French 2005; Dayamba et al. 2008; Scott et al. 2010), in Mediterranean Shrubland (Reyes and Trabaud 2009) and in South American grasslands (Overbeck et al. 2006; Gonzalez and Ghermandi 2012). Soil temperatures at $1 \mathrm{~cm}$ depth have been recorded reaching $29-55^{\circ} \mathrm{C}$ during a fire in Brazilian savannas (Miranda et al. 1993; 2009), a depth where the majority of the grass seed bank is maintained (Musso et al. 2014). In Brazilian wet grasslands, temperatures at $1 \mathrm{~cm}$ aboveground may stay under $100^{\circ} \mathrm{C}$ most part of the time, with temperatures above $60^{\circ} \mathrm{C}$ having less than 2 min of residence time during a fire event (Schmidt 2011). Taken together, the high survival rates displayed by these seeds after the $80^{\circ} \mathrm{C}$ treatment suggests that grass seeds in the soil seed bank and over the soil surface would be able to survive low temperatures generated during a fire in both open savanna and wet grassland.

In contrast to the effects of heat shock of $80^{\circ} \mathrm{C}$, we found that in 11 out of 14 species there was a negative effect of heat shock after $110^{\circ} \mathrm{C}$ treatments for 2.5 and 5 min on seed survival. Studies conducted with species from fire-prone ecosystems show contrasting results: 
Seeds of many grass species of an Australian savanna survived after treatment of $120^{\circ} \mathrm{C}$ for 2 min (Clarke and French 2005), seeds of five native grass species of a Sudanese savanna tolerated temperatures of $120^{\circ} \mathrm{C}$ for $2.5 \mathrm{~min}$ (Dayamba et al. 2008), seeds of two grass species of the Mediterranean Shrubland survived after being exposed to $110^{\circ} \mathrm{C}$ for 5 and $10 \mathrm{~min}$ (Reyes and Trabaud 2009), while in Ethiopia, seeds in two out of three species survived well at $120^{\circ} \mathrm{C}$ for $1 \mathrm{~min}$, but did not survive $120^{\circ} \mathrm{C}$ for 5 min treatment (Gashaw and Michelsen 2002). In a Brazilian temperate grassland on the other hand, seeds of three grass species survived after a heat shock of $110^{\circ} \mathrm{C}$ for 2 min but another three did not (Overbeck et al. 2006). Unlike our study sites, the majority of the habitats listed above have a shrub component to their community composition, and are likely to produce longer duration burns that could increase soil heating and residence times. This would result in more species having adapted to tolerate heating up to $110^{\circ} \mathrm{C}$ or higher. So, with exception of Aristida riparia,

Aristida setifolia and Sacciolepis myurus, which survived well to $110^{\circ} \mathrm{C}$, our study species might not tolerate hotter burns, with soil temperatures above this level rarely occurring.

\section{Dormancy and habitat effects on seed tolerance to heating} Dormant seeds were shown to be more tolerant to the heat shock than non-dormant seeds, irrespective of whether the seeds were from open savanna or wet grassland. Seed dormancy in grass species from seasonal savannas has been suggested to constitute a droughtavoidance syndrome, synchronizing germination to the beginning of next rainy season, thus reducing the probability of seedling death during the dry season (Mott 1978; Veenendaal et al. 1996; Scott et al. 2010). Brazilian grass species disperse their seeds through the rainy season (Tannus et al. 2006; Munhoz and Felfili 2007b; Ramos et al. 2014) and the natural time of fire occurrence is at the beginning of the rainy season (Ramos-Neto and Pivello 2000). So, when the fire occurs seeds of grasses from previous reproduction are already dispersed and presumably are in the soil. 
Seed dormancy and tolerance to heat shock in these environments seems to provide an advantage that could increase fitness of grass species in two ways, firstly by reducing the probability of germination before the next rainy season, and secondly by maintaining seed viability while they remain in the soil seed bank during fires. Germinating in a less competitive post-fire environment could be a further strategy to increase plant fitness (Zimmermann et al. 2008). Seeds of Aristida setifolia, Axonopus barbigerus, E. inflexa and Gymnopogon spicatus (Musso et al. 2014), grass species from Brazilian savannas, have shown increased germination at temperatures mimicking post-fire soil conditions $\left(45^{\circ} \mathrm{C} / 10^{\circ} \mathrm{C}\right)$, providing further evidence that these species have adapted to taking advantage of the post-fire environment.

Lower temperatures occur in wet grasslands during fires than in open savannas and species survived more in open savannas at $80^{\circ} \mathrm{C}(5 \mathrm{~min})$ than in wet grasslands. However, there were no differences in survivorship at $80^{\circ} \mathrm{C}(2.5 \mathrm{~min})$ or $110^{\circ} \mathrm{C}$ heating treatments. Thus, we partially corroborate our hypothesis that seeds of species from open savannas are more tolerant to heating than those of wet grasslands. The temperature of $80^{\circ} \mathrm{C}$ can occur in low temperature fires and our results suggest that seeds of species from open savannas might survive more than seeds from wet grasslands in prolonged fires. Natural fires are caused by lightning and are concentrated at the transitions between dry to rainy season and at the beginning of the rainy season (Ramos-Neto and Pivello 2000). On the other hand, human induced fires are concentrated in the dry season (Ramos-Neto and Pivello 2000).

The impacts of fire can be related to fire season (Williams et al. 2004); high temperatures $\left(>100^{\circ} \mathrm{C}\right)$ can penetrate deeper into the soil in late dry season fires compared to early dry season fires in Australian savannas (Williams et al. 2004). Our results suggest that seeds of open savanna grass species are therefore better adapted to low temperature fires that 
occur during the rainy season, suggesting that a change in fire season might negatively impact seed survival of these species via an increase in soil temperatures. Additionally, the residence times of high temperatures are influenced by fire season; temperatures above $60^{\circ} \mathrm{C}$ had shorter residence times in early dry season fires (around $1 \mathrm{~min}$ ) than in late dry season fires (more than $5 \mathrm{~min}$ ) in African savannas (Dayamba et al. 2010). Seeds of species from wet grasslands do not tolerate prolonged times of exposure $(5 \mathrm{~min})$, even to low temperatures, and a change in fire season may therefore negatively affect seed survival of species from this habitat.

Subsequently, changes in fire season might negatively affect seed survival of grass species in open savannas and wet grasslands due to an increase in soil temperatures and high temperatures residence times, respectively.

Environment features such as fuel moisture and air temperature strongly influence fire temperature and behavior during burning (Kauffman et al. 1994; Mistry 1998). Mean air temperature increases at both global and local scales, as well as changes in precipitation distribution, are projected to occur over the next century due to climate change (IPCC 2013). A prolonged dry season might make the fuel dryer, resulting in more severe and prolonged fires. Our findings suggest that small increases in fire temperatures (from $80^{\circ} \mathrm{C}$ to $110^{\circ} \mathrm{C}$ ) can kill grass seeds and thus negatively affect seedling recruitment in most grass species from open savannas and wet grasslands. In general, climate change may result in higher survival for fire tolerant grass species (only three species Aristida riparia, Aristida setifolia and Sacciolepis myurus in our study) in comparison with fire non-tolerant grass species, which in turn may deeply affect population dynamics and community structure in Brazilian open savannas and wet grasslands.

In conclusion, our results suggest that species with dormant seeds experience selection for covarying characteristics that allow tolerance to heating in high temperature fires. Additionally, grass seeds from Brazilian open savannas and wet grasslands are tolerant to low 
temperature fire events. Habitat moisture and seed dormancy display either a negative or positive relationship with fire tolerance, respectively, suggesting that (i) dry habitats may suffer higher temperatures or frequent fire events than wet habitats, and (ii) the duration of time that seeds stay exposed to burn may be a key driver of the evolution of seed fire tolerance.

\section{Acknowledgments}

We acknowledge CAPES, University of Brasília and Embrapa for the financial support to this study. José F. M. Valls was supported by a CNPq Scholarship during this study. We thank to Eduardo M. Barbosa and Augusto C. Franco for their helpful comments in the previous version of this paper. Mark Ooi was supported by an Australian Research Council Linkage Project grant (LP110100527) during this study. We confirm that there are no known conflicts of interest associated with this publication.

\section{References}

Aires SS, Sato MN, Miranda HS (2013) Seed characterization and direct sowing of native grass species as a management tool. Grass and Forage Science 69, 470-478.

Baskin CC, Baskin JM (Eds) (2014) 'Seeds: Ecology, Biogeography, and Evolution of Dormancy and Germination’. 2nd. ed. (Elsevier/Academic Press: San Diego).

Baskin JM, Baskin CC (2004) A classification system for seed dormancy. Seed Science Research 14, 1-16.

Bates D, Maechler M, Bolker B, Walker S (2014)_lme4: Linear mixed-effects models using Eigen and S4_. R package version 1.1-7, <URL: http://CRAN.R-project.org/package=lme4>. Bourlière F, Hadley M (1983) Present-day savannas: an overview. In: 'Ecosystems of the world -tropical savannas’ (Ed DW Goodall) pp. 1-17. (Elsevier: Amsterdam).

Cianciaruso MV, Batalha MA (2008) A year in a Cerrado wet grassland: a non-seasonal island in a seasonal savanna environment. Brazilian Journal of Biology 68, 495-501. 
Clarke S, French K (2005) Germination response to heat and smoke of 22 Poaceae species from grassy woodlands. Australian Journal of Botany 53, 445-454.

Dayamba SD, Savadogo P, Zida D, Sawadogo L, Tiveau D, Oden PC (2010) Fire temperature and residence time during dry season burning in a Sudanian savanna-woodland of West Africa with implication for seed germination. Journal of Forestry Research 21, 445-450. Dayamba SD, Tigabu M, Sawadogo L, Oden P (2008) Seed germination of herbaceous and woody species of the Sudanian savanna-woodland in response to heat shock and smoke. Forest Ecology and Management 256, 462-470.

Dormann CF, Elith J, Bacher S, Buchmann C, Carl G, Carré G, Marquéz JRG, Gruber B, Lafourcade B, Leitão PJ, Münkemüller T, McClean C, Osborne PE, Reineking B, Schröder B, Skidmore AK, Zurell D, Lautenbach S (2012) Collinearity: a review of methods to deal with it and a simulation study evaluating their performance. Ecography 35, 001-020.

Eiten G (1972) The cerrado vegetation of Brazil. The Botanical Review 38, 201-241.

Eiten G (1978) Delimitation of the cerrado concept. Vegetatio 36, 169-178.

Fidelis A, Lyra MFDS, Pivello VR (2013) Above- and below-ground biomass and carbon dynamics in Brazilian Cerrado wet grasslands. Journal of Vegetation Science 24, 356-364. Gashaw M, Michelsen A (2002) Influence of heat shock on seed germination of plants from regularly burnt savanna woodlands and grasslands in Ethiopia. Plant Ecology 159, 83-93. Gonzalez SL, Ghermandi L (2012) Fire cue effects on seed germination of six species of northwestern Patagonian grasslands. Natural Hazards and Earth System Sciences 12, 27532758.

Grass Phylogeny Working Group II (2012) New grass phylogeny resolves deep evolutionary relationships and discovers C4 origins. New Phytologist 193, 304-312. 
Hoffmann WA, Jaconis S, Mckinley KL, Geiger EL, Gotsch SG, Franco AC (2012) Fuels or microclimate? Understanding the drivers of fire feedbacks at savanna-forest boundaries. Austral Ecology 37, 634-643.

Hothorn T, Bretz F, Westfall P (2008) Simultaneous Inference in General Parametric Models. Biometrical Journal 50, 346-363.

IPCC (2013) Annex I: Atlas of Global and Regional Climate Projections [van Oldenborgh G.J., M. Collins, J. Arblaster, J.H. Christensen, J. Marotzke, S.B. Power, M. Rummukainen and T. Zhou (eds.)]. In: Climate Change 2013: The Physical Science Basis. Contribution of Working Group I to the Fifth Assessment Report of the Intergovernmental Panel on Climate

Change [Stocker, T.F., D. Qin, G.-K. Plattner, M. Tignor, S.K. Allen, J. Boschung, A. Nauels, Y. Xia, V. Bex and P.M. Midgley (eds.)]. Cambridge University Press, Cambridge, United Kingdom and New York, NY, US.

Kauffmann JB, Cummings DL, Ward DE (1994) Relationships of fire, biomass and nutrient dynamics along a vegetation gradient in the Brazilian cerrado. Journal of Ecology 82, 519531.

Marinho MS, Miranda HS (2013) Efeito do Fogo Anual na Mortalidade e no Banco de Sementes de Andropogon gayanus Kunth. no Parque Nacional de Brasília/DF. Biodiversidade Brasileira 3(2), 149-158.

Medina E (1982) Physiological ecology of neotropical savanna plants. In: 'Ecology of tropical savannas'(Eds BJ Huntley, BH Walker) pp. 308-335. (Springer-Verlag: Berlin). Meirelles ML, Franco AC, Frerreira EAB, Randow CV (2010) Fluxo diurno de CO2 soloplanta-atmosfera em um campo úmido do cerrado. Boletim de Pesquisa e Desenvolvimento 274, Embrapa Cerrados, Planaltina. [In Portuguese].

Miranda AC, Miranda H, Dias ODF, Dias BFDS (1993) Soil and air temperatures during prescribed cerrado fires in Central Brazil. Journal of Tropical Ecology 9, 313-320. 
Miranda HS, Sato MN, Neto WN, Aires FS (2009) Fires in the Cerrado, the Brazilian savanna. In: 'Tropical fire ecology'(Ed Cochrane, MA) 427-450pp. (Praxis: Chischester). Miranda HS, Neto WN, Neves BMC (2010) Caracterização das queimadas de Cerrado. In: Efeitos do regime do fogo sobre a estrutura de comunidades de cerrado: Resultados do Projeto Fogo’. (Org HS Miranda) 23-33pp. (IBAMA: Brasília). [In Portuguese]. Mistry J (1998) Fire in the cerrado (savannas) of Brazil: an ecological review. Progress in Physical Geography 22(4), 425-448.

Mott JJ (1978) Dormancy and Germination in Five Native Grass Species from Savannah Woodland Communities of the Northern Territory. Australian Journal of Botany 26, 621631.

Munhoz CBR, Felfili JM (2007a) Florística do estrato herbáceo-subarbustivo de um campo limpo úmido em Brasília, Brasil. Biota Neotropica 7, 205-215.

Munhoz CBR, Felfili JM (2007b) Reproductive phenology of an herbaceous-subshrub layer of a Savannah (Campo Sujo) in the Cerrado Biosphere Reserve I, Brazil. Brazilian journal of biology 67, 299-308.

Musso C, Miranda HS, Aires SS, Bastos AC, Soares AMVM, Loureiro S (2014) Simulated post-fire temperature affects germination of native and invasive grasses in cerrado (Brazilian savanna). Plant Ecology \& Diversity 8, 219-227.

Ooi MKJ, Denham AJ, Santana VM, Auld TD (2014) Temperature thresholds of physically dormant seeds and plant functional response to fire: variation among species and relative impact of climate change. Ecology and Evolution 4, 656-671.

Overbeck GE, Müller SC, Pillar VD, Pfadenhauer J (2006) No heat stimulated germination found in herbaceous species from burned subtropical grassland. Plant Ecology 184, 237-243. Paula S, Pausas JG (2008) Burning seeds: germinative response to heat treatments in relation to resprouting ability. Journal of Ecology 96, 543-552. 
411 R Development Core Team (2014) R: A language and environment for statistical computing.

412 R Foundation for Statistical Computing, Vienna, Austria. URL http://www.R-project.org/.

413 Ramos DM, Diniz P, Valls JFM (2014) Habitat filtering and interspecific competition

414 influence phenological diversity in an assemblage of Neotropical savanna grasses. Brazilian

415 Journal of Botany 37(1), 29-36.

416 Ramos-Neto MB, Pivello VR (2000) Lightning Fires in a Brazilian Savanna National Park:

417 Rethinking Management Strategies. Environmental Management 26, 675-684.

418 Reyes O, Trabaud L (2009) Germination behaviour of 14 Mediterranean species in relation to 419 fire factors: smoke and heat. Plant Ecology 202, 113-121.

420 Ribeiro LC, Borghetti F (2013) Comparative effects of desiccation, heat shock and high 421 temperatures on seed germination of savanna and forest tree species. Austral Ecology 39, $422 \quad 267-278$.

423 Ribeiro LC, Pedrosa M, Borghetti F (2012) Heat shock effects on seed germination of five 424 Brazilian savanna species. Plant Biology 15, 1-6.

425 Rossatto DR, de Carvalho LRS, Villalobos-Vega R, Sternberg LSL, Franco AC (2012) Depth 426 of water uptake in woody plants relates to groundwater level and vegetation structure along a topographic gradient in a neotropical savanna. Environmental and Experimental Botany 77, $428 \quad 259-266$.

429 Sarmiento G (1984) The ecology of neotropical savannas. Harvard University Press, 430 Cambridge, MA.

431 Schmidt IB (2011) Effects of Local Ecological Knowledge, Harvest and Fire on Golden-grass 432 (Syngonanthus nitens, Eriocaulaceae), a non-timber forest product (NTFP) from the 433 Brazilian Savanna. PhD Thesis, University of Hawai'i at Manoa, US.

434 Scott K, Setterfield S, Douglas M, Andersen A (2010) Soil seed banks confer resilience to 435 savanna grass-layer plants during seasonal disturbance. Acta Oecologica 36, 202-210. 
Sileshi GW (2012) A critique of current trends in the statistical analysis of seed germination and viability data. Seed Science Research 22, 145-159.

Tannus JLS, Assis MA, Morellato LPC (2006) Fenologia reprodutiva em campo sujo e campo úmido numa área de cerrado no sudeste do Brasil, Itirapina-SP. Biota Neotropica 6, 1-27. Thomas PB, Morris EC, Auld TD (2003) Interactive effects of heat shock and smoke on germination of nine species forming soil seed banks within the Sydney region. Austral Ecology 28, 674-683.

Tielbörger K, Prasse R (2009) Do seeds sense each other? Testing for density-dependent germination in desert perennial plants. Oikos 118, 792-800.

Veenendaal EM, Ernst WHO, Modise GS (1996) Effect of seasonal rainfall pattern on seedling emergence and establishment of grasses in a savanna in south-eastern Botswana. Journal of Arid Environments 32, 305-317.

Williams P, Congdon RA, Grice AC, Clarke PJ (2004) Soil temperature and depth of legume germination during early and late dry season fires in a tropical eucalypt savanna of northeastern Australia. Austral Ecololgy 29, 258-263.

Williams RJ, Gill AM, Moore PHR (2003) Fire behavior. In: 'Fire in Tropical Savannas, the Kapalga Experiment’. (Eds AN Andersen, GD Cook, RJ Williams). 199 p. (Springer-Verlag: New York).

Zimmermann J, Higgins SI, Grimm V, Hoffmann J, Münkemüller T, Linstädter A (2008)

Recruitment filters in a perennial grassland: the interactive roles of fire, competitors, moisture and seed availability. Journal of Ecology 96, 1033-1044.

Zuur AF, Ieno EN, Walker NJ, Saveliev AA, Smith GM (Eds) (2009) `Mixed effects models an extensions in ecology with R.'(Springer: New York). 

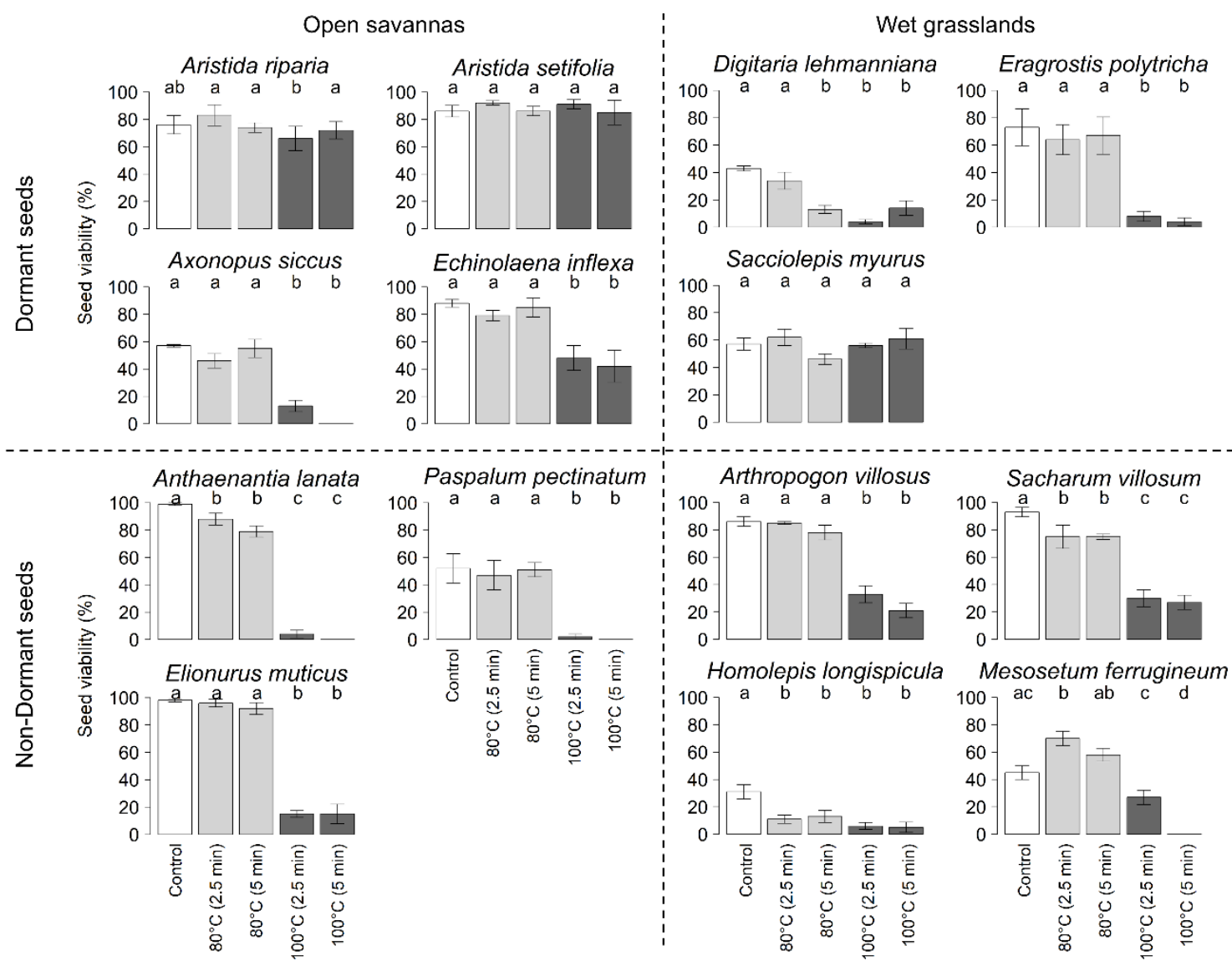

Fig.1 Effects of heat shock treatments on the viability of seeds of Brazilian grass species from

462 open savannas and wet grasslands. Mean viability $(\%) \pm$ Confidence Interval. Means followed by the same letter do not differ significantly according to multiple comparisons made with glht command. 


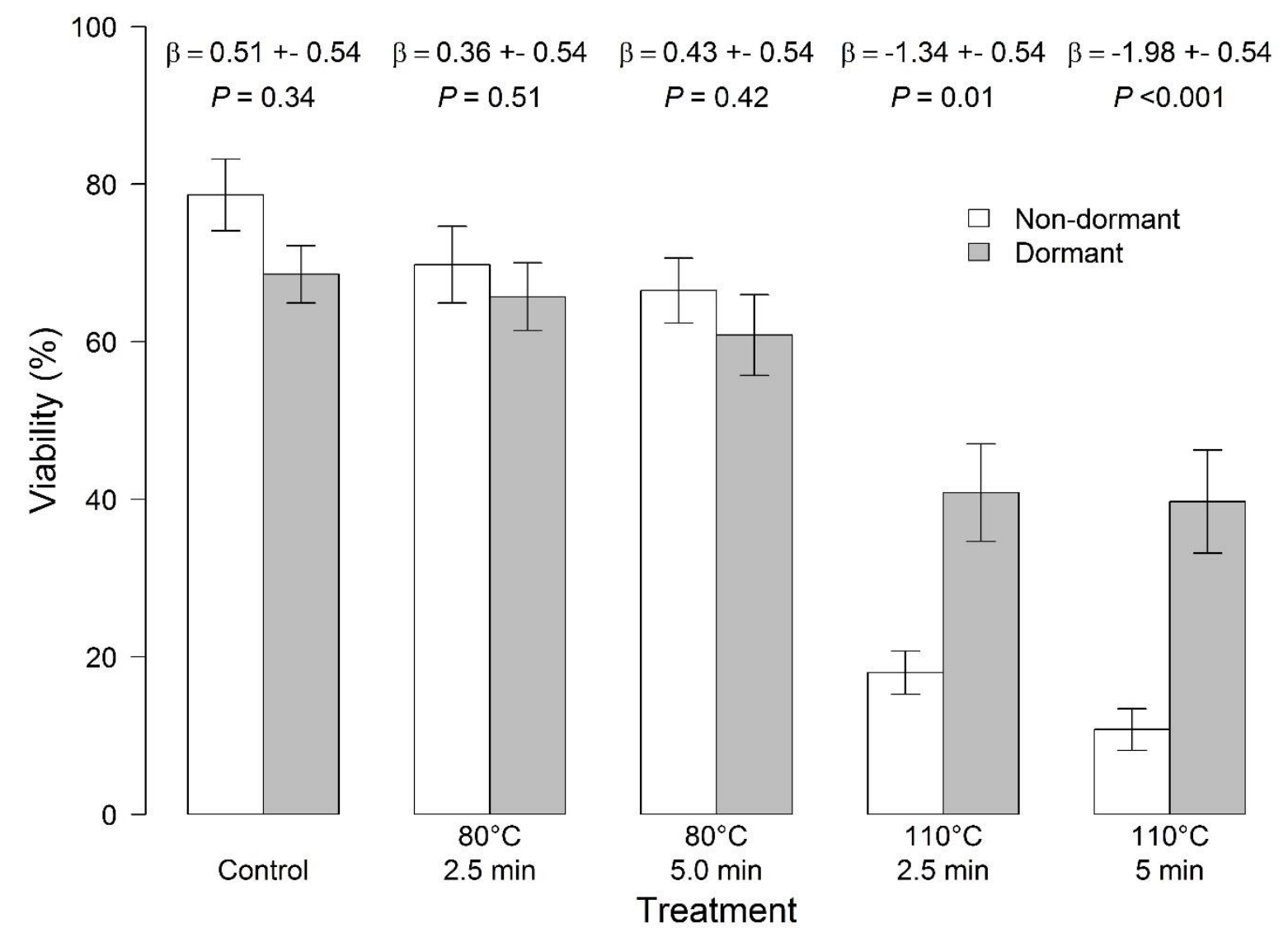

Fig.2 Effects of heat shock treatments on the viability of dormant and non-dormant seeds of 468 Brazilian grass species from open savannas and wet grasslands. White bars $=$ Non-dormant 469 seeds; Grey bars $=$ Dormant seeds. Mean viability $(\%) \pm$ Confidence Interval. 


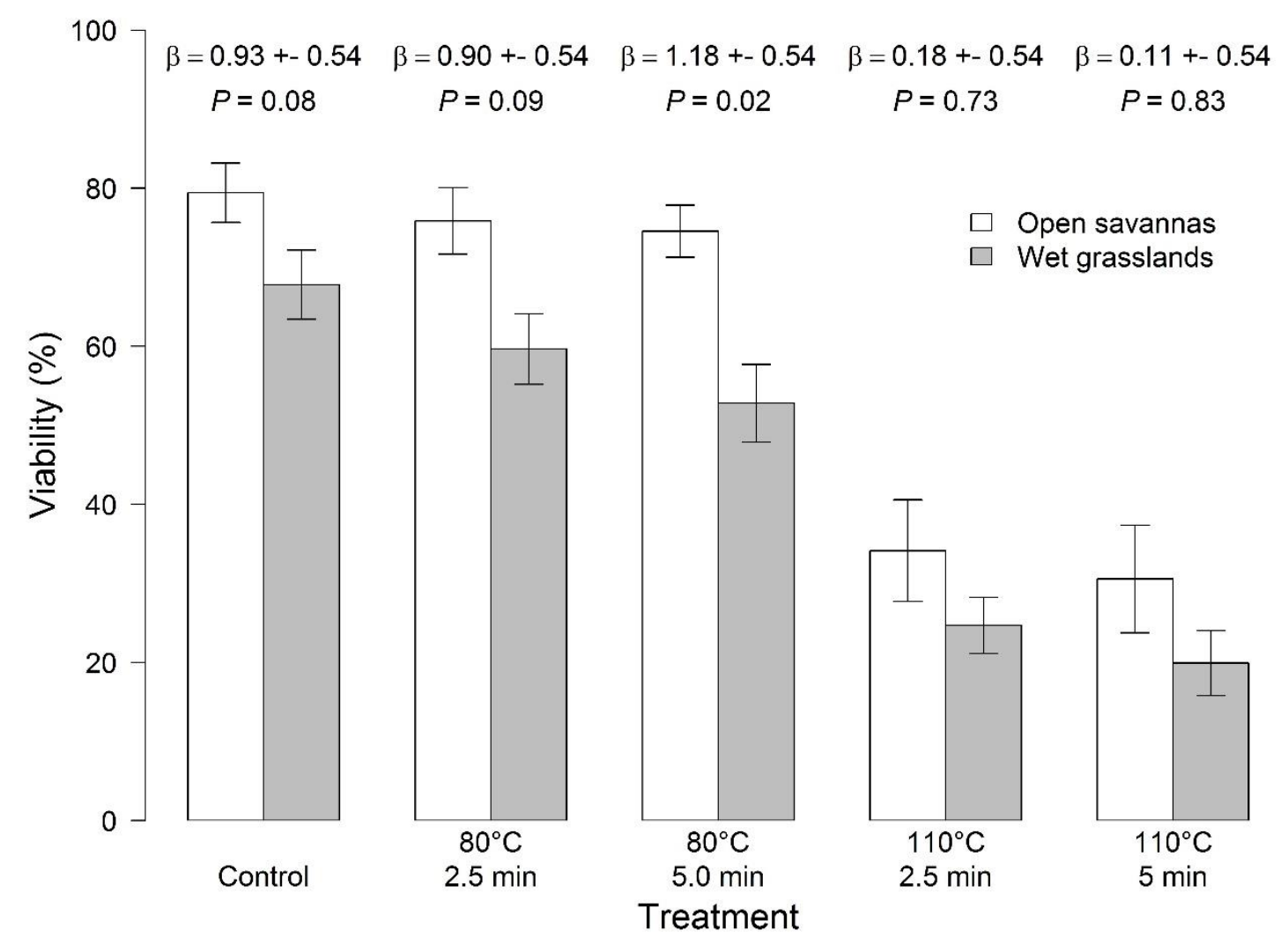

Fig.3 Effects of heat shock treatments on the viability of seeds of Brazilian grass species from open savannas and wet grasslands. White bars = Open savannas; Grey bars $=$ Wet grasslands. Mean viability $(\%) \pm$ Confidence Interval. 
Table 1. Seed germination (G), viability (V) and dormancy of native grass species from open savannas and wet grasslands used in the heat shock treatments. Sites and habitat of collection and months of storage at the heating treatments time.

\begin{tabular}{|c|c|c|c|c|c|}
\hline Species & Habitat & Site & $\begin{array}{c}\mathrm{G} \\
(\%)\end{array}$ & $\begin{array}{c}\mathrm{V} \\
(\%)\end{array}$ & Dormancy \\
\hline
\end{tabular}

\begin{tabular}{|c|c|c|c|c|c|c|}
\hline Anthaenantia lanata (Kunth) Benth. & Open savanna & PNB & 81 & 81 & ND & 8 \\
\hline Aristida riparia Trin. & Open savanna & FAL & 10 & 65 & $\mathrm{D}$ & 5 \\
\hline Aristida setifolia Kunth & Open savanna & FAL & 13 & 82 & $\mathrm{D}$ & 8 \\
\hline Arthropogon villosus Nees & Wet grassland & PNB & 97 & 97 & ND & 1 \\
\hline $\begin{array}{l}\text { Axonopus siccus var. siccus (Nees) } \\
\text { Kuhlm. }\end{array}$ & Open savanna & FAL & 1 & 76 & $\mathrm{D}$ & 7 \\
\hline Digitaria lehmanniana Henrard & Wet grassland & PNB & 0 & 92 & $\mathrm{D}$ & 7 \\
\hline Echinolaena inflexa (Poir.) Chase & Open savanna & FAL & 0 & 97 & $\mathrm{D}$ & 10 \\
\hline Elionurus muticus (Spreng.) Kuntze & Open savanna & PNB & 99 & 99 & ND & 8 \\
\hline Eragrostis polytricha Nees & Wet grassland & PNB & 0 & 67 & $\mathrm{D}$ & 10 \\
\hline Saccharum villosum Steud. & Wet grassland & PNB & 89 & 92 & ND & 2 \\
\hline Homolepis longispicula (Döll) Chase & Wet grassland & PNB & 57 & 57 & ND & 11 \\
\hline Mesosetum ferrugineum (Trin.) Chase & Wet grassland & PNB & 68 & 68 & ND & 2 \\
\hline Paspalum pectinatum Nees ex Trin. & Open savanna & PNB & 54 & 54 & ND & 8 \\
\hline Sacciolepis myurus (Lam.) Chase & Wet grassland & FAL & 8 & 94 & $\mathrm{D}$ & 11 \\
\hline
\end{tabular}

PNB = National Park of Brasília; FAL = Fazenda Água Limpa from University of Brasília. D = Dormant; ND = Non-dormant. 
CAPÍTULO 3

Temporal changes in seed dormancy, germination and viability of grasses from Neotropical savannas 
Temporal changes in seed dormancy, germination and viability of grasses from Neotropical savannas

Desirée M. Ramos ${ }^{1,2}$; Fernanda. L.Siva ${ }^{1}$; Fabian Borghetti ${ }^{1}$ and José F. M. Valls ${ }^{1,2}$

1 - Department of Botany - University of Brasília/Brazil; 2 - Brazilian Corporation of Agricultural Research/Embrapa, Brasília/Brazil.

Correspondence:

D. M. Ramos, Embrapa Recursos Genéticos e Biotecnologia. Parque Estação Biológica PqEB, s/no. Caixa Postal 02372, P.O Box: 70770-900. Brasília, Distrito Federal, Brazil.

E-mail: desibio@gmail.com 


\section{Abstract}

2 Savannas are ecosystems with scattered trees and high grass cover. The Cerrado, the

3 Brazilian savanna, has been strongly degraded during the past three decades. The use of

4 native grass species to recover degraded areas is strongly advised. However, seed

5 germination and longevity patterns of native species are poorly understood. This study

6 aimed to investigate the viability, dormancy and germination of fresh and dry-stored

7 seeds of 28 native grass species from the Cerrado. After seed collection, germination

8 trials were performed every three months for up to one year of dry storage. Dry storage

9 had a negative effect on seed viability for twelve species. Among these species,

10 germination of fresh seeds was high for eight species and four were dormant. Thus,

11 results suggest the use of seeds from these eight species up to one year after collection.

12 On the other hand, viability of seeds from sixteen species was not affected by dry

13 storage. Fresh seeds from five species were non-dormant and able to be sowed at any

14 time for up to one year. Eleven species were dormant and dry storage progressively

15 alleviated the dormancy levels for seven of them. Dry storage is suggested for these

16 seven species to break seed dormancy before sowing.

17 Keywords: seed dormancy; degraded areas; recovering; germination; open savanna;

18 wet grassland. 
The Cerrado, a tropical savanna covering about $22 \%$ of the Brazilian territory

(Jepson 2005), has been strongly degraded and replaced by crop cultivation and pasture for cattle during the past three decades (Jepson 2005). Estimates indicate that over 50\% of original Cerrado area has already disappeared (Klink and Machado, 2005). Open savannas (campos sujos) and wet grasslands (campos úmidos) are ecosystems mainly characterized by grasses and scattered trees inside the Cerrado domain, and are vulnerable ecosystems because they are easily replaced by exotic grasses for cattle forage or crop cultivation. During recent years, the Brazilian government has strongly advised the use of native grass species for recovering degraded areas. However, the use of exotic grass species has been used instead of native species due to the unavailability of their seeds in the market and the lack of information about their viability and germination behavior.

Grasses belong to one of the most representative families (Poaceae) in the herbaceous layer of the Cerrado ( 600 species, Filgueiras et al., 2014) and, since they are affected by water shortage during the dry season, their flowering and fruiting is mostly restricted to the rainy season (Tannus et al., 2006; Munhoz and Felfili, 2007; Ramos et al., 2014). The availability of seeds from these grass species for collection occurs mainly during the rainy season (Silva and Ataroff, 1985; Almeida, 1995), with some species dispersing seeds during the dry season as well (Almeida, 1995). However, seed germination and viability of several grass species from savannas show temporal changes during dry storage, according to seed dormancy and longevity patterns (Baskin and Baskin, 2014). Thus, the knowledge of germination behavior and viability of fresh seeds along a gradient of storage periods may be useful to predict the seed longevity of 
species from tropical savannas, with strong implications regarding the choice of species for recovering degraded areas.

In savannas, there is a high variation in the level of dormancy among dispersed grass seeds (Baskin and Baskin, 1998; Baskin and Baskin, 2014). The most common type of dormancy in grasses is non-deep physiological dormancy (Baskin and Baskin, 1998; Baskin and Baskin, 2014). The main characteristics of this type of dormancy are that seeds absorb moisture easily when watered, and the level of dormancy is progressively alleviated when the seeds are subjected to dry storage (Baskin and Baskin, 2014; Baskin and Baskin, 2004), increasing germination rates with storage time. Thus, dry storage may be used to improve germination of grass species with the purpose of recovering degraded areas. However, it is extremely necessary to understand whether these seeds remain viable during a period of dry storage.

\section{Despite their importance in savanna dynamics and their large coverage in} savannas worldwide, grass seeds' levels of dormancy and patterns of germination, as well as their responses to dry storage, are poorly understood in the Brazilian savannas. Thus, the aim of this study was to verify the temporal patterns of savanna grass species' seed germination, dormancy and longevity, testing germination with freshly collected seeds and after dry storage for up to one year. The results are discussed in relation to the specific potential of native grass species to be used to recover degraded areas based on germination and viability behavior after dry storage.

\section{Material and Methods}

Study area and seed collection

The dispersal units in grasses are generally complex structures composed by a caryopsis (fruit), a caryopsis with bracts (lemma and palea) and occasionally 
inflorescences (commonly called seeds). Seeds from 28 native perennial grass species

(Table 1) from Brazilian open savannas and wet grasslands were collected in 2012 and 2013, in two protected areas of Brasília: Fazenda Água Limpa from the University of Brasília (FAL - 1558'43.06"S and 4756'21.41"W, $1.197 \mathrm{~m}$ ) and the National Park of Brasília (PNB - 15³8'46.22"S and 4800'19.75"W, $1.178 \mathrm{~m}$ ). The climate of the region is seasonal with two well-defined seasons: a wet summer and a dry winter (Fig. 1).

Patches of savannas, forests and grasslands compose the study sites. Plants were monitored regularly to ensure that seeds were mature at dispersal and then manually collected. Monitoring of the grass populations selected for this study allowed the estimate of the seed dispersal periods for each species. After collection, the seeds were stored in paper bags at room temperature (27-maxima and $17^{\circ} \mathrm{C}$-minima), measured during the storage period with a thermometer of maxima and minima temperatures. The average relative humidity in the region was $43-80 \%$ during the study period (data from BDMEP/INMET).

Viability and germination by storage time

To verify the degree of viability and the dormancy level of the seeds, germination trials were conducted with freshly collected seeds. To test the effect of dry storage on the degree of viability and the germination percentages, trials were conducted after 3, 6, 9 and 12 months of dry storage. Five replicates of 20 seeds were used for each species for each treatment, except for P. maculosum, A. goyazense, $H$. longispicula and S. sanguineum, where five replicates of 10 seeds per treatment were used due to the limited quantity of seeds. The germination experiments were conducted in chambers regulated for a $28 / 18^{\circ} \mathrm{C}$ cycle for day/night, respectively, under a photoperiod of $12 \mathrm{~h}$ of white light. The temperatures were set according to the average minimum and maximum temperatures recorded during the wet summer (Fig. 1), which 
represents the growing season for most savanna species in the Cerrado, including grasses. Germination was recorded daily for up to 30 days and the criterion for seed germination was emergence of the radicle. After each germination trial, the viability of the non-germinated seeds was tested using $1 \%$ tetrazolium chloride solution. The seeds were placed in contact with tetrazolium solution for 24 hours in the dark at $30^{\circ} \mathrm{C}$ in a germination chamber. Seeds were considered viable when embryos were dark pink or red. We considered as dormant the species whose viable seeds did not reach at least $50 \%$ of germination.

Statistical Analysis

We analyzed the effect of dry storage treatments on seed viability and germination for each species separately, because the aim was to verify the species' specific potential for recovering degraded areas. First, viability was analyzed (presence/absence) with Generalized Linear Models (GLM, binomial error distribution, see Zuur et al., 2009). Dry storage treatment (0, 3, 6, 9 and 12 months) was included as a fixed independent variable. Seeds inside the petri dishes were placed under the same environment that could affect the germination pattern of neighbors' seeds (Tielbörger and Prasse 2009), resulting in autocorrelation of errors (Sileshi 2012). Therefore, each seed was used as an experimental unity and replication $(\mathrm{N}=5)$ as a fixed independent variable, in order to control the autocorrelation of errors. Post-hoc multiple comparisons were conducted between levels of the significant fixed factors, using the single step method with P-values adjustment and the glht command of multcomp package (Hothorn et al., 2008). Second, germination was analyzed with the same model procedure and steps using viability analysis. We included in the model only the germination of viable seeds, since there is no need to verify germination of a dead seed. In the germination and viability analysis, it is not possible to estimate parameters in GLM in cases of total 
absence of value, so in these situations one absent value (0) was replaced with one present value (1) in each replication. All data was analyzed with R 3.1.2 software ( $R$ Core Team 2014).

121

\section{Results}

Dry storage had a negative effect on seed viability for twelve grass species (Fig. 1). Seeds from these species generally died after six to twelve months of dry storage. Germination of freshly collected seeds was low or absent for four of these species: Panicum olyroides, Paspalum carinatum, P. glaucencens and I. camporum (Fig. 1; Table 1). Considering that these species showed moderate to high levels of viability, we conclude that their seeds are dispersed with high levels of dormancy (Table 1). On the other hand, germination of fresh seeds was above $50 \%$ for eight species: Elionurus muticus, Arthropogon villosus, Mesosetum ferrugineum, Paspalum erianthum, $P$. guttatum, P. pectinatum, Homolepis longispicula and Anthaenantia lanata (Fig. 1;

Table 1), so these species disperse seeds with no dormancy.

Dry storage did not affect seed viability for sixteen grass species (Fig. 2). Seeds from these species were viable even after twelve months of dry storage. The germination of these species was variable: Fresh seeds of eleven species did not germinate, and were deemed dormant, while seeds of five species had high levels of germination, and were deemed non-dormant (Fig. 2; Table 1). Germination increased after dry storage for seven of the eleven dormant species (Fig. 2). On the other hand, germination remained low for four of the eleven dormant species: Paspalum maculosum, Setaria parviflora, Aristida recurvata and Axonopus siccus (Fig. 2). Seed germination remained high and constant for five of the non-dormant species across all storage periods: Andropogon leucostachyus, Aristida gibbosa, Saccharum villosum, Schizachyrium sanguineum and Paspalum polyphyllum (Fig. 2). 


\section{Discussion}

Results show that nearly half of the species had seeds which died with dry storage (12 sp.) and the remaining species had seeds with high longevity across all storage periods (16 sp.). This pattern was also found in grass species from the African savannas (Tessema et al., 2011), where seeds with high longevity patterns can become part of a seed bank (Tessema et al., 2011), increasing resilience after disturbance in savannas (Scott et al., 2010). Among the species negatively affected by dry storage, four are not recommended for restoration purposes due to low levels of germination: $P$. olyroides, $P$. carinatum, $P$. glaucencens and I. camporum. Another negative aspect is that $P$. carinatum has a low percentage of fertile seeds (7.8\%; Aires et al., 2013) which could become an obstacle for seed collection.

Although seeds of another eight species died after dry storage, they had high levels of germination: E. muticus, A. villosus, M. ferrugineum, $P$. erianthum, $P$. guttatum, P. pectinatum, H. longispicula and A. lanata. These species could be used for restoration during the first months after seed dispersal, which occurs between December and January. Additionally, E. muticus, M. ferrugineum, P. erianthum, and P. pectinatum are tall and robust plants $(\sim 30-70 \mathrm{~cm}$ height $)$ and these traits may confer advantage for colonizing areas.

Seed longevity of sixteen grass species was not affected by dry storage and five of them were non-dormant. Andropogon leucostachyus produces non-dormant seeds and has a high percentage of fertile seeds (60\%; Aires et al., 2013). In addition, seed germination of A. leucostachyus was high in fresh seeds and after three, nine and twelve months of dry storage, resulting in broad opportunities for sowing throughout the year.

Grass species' seeds commonly have non-deep physiological dormancy and undergo after-ripening during dry storage, increasing germination (Mott, 1978; Baskin and 
Baskin, 2014). Indeed, germination increased in seven of the eleven dormant species after dry storage: S. myurus, A. setifolia, E. inflexa, C. cirrhosum, E. polytricha, A. riparia and A. goyazense. These species can be stored without losing viability but their sowing is possible only after about 6 months of dry storage, which is the time necessary to increase germination. A. riparia and A. setifolia have a high percentage of fertile seeds (90 and 73\%, respectively; Aires et al., 2013). Moreover, these species are robust plants (130cm height) and have high longevity patterns associated with high germination rates after dry storage. Thus, A. riparia and A. setifolia have high potential for the purpose of recovering degraded areas. for recovering degraded areas. However, there are other important uses of these species that must be considered. First, grasses are commonly used as ornamental plants in gardens around the world. Unfortunately, local researches and producers have not given enough consideration to native species from the Cerrado. This may occur because there is not enough information about native species in the literature. Indeed, some species such as $A$. riparia and $C$. cirrhosum, have high ornamental potential to be explored. Second, several native grass species have high forage value for cattle. For example, $E$. inflexa is selected for cattle grazing (Almeida et al., 1987; Leite et al., 1997). Exotic grasses frequently used as forage for cattle are spreading fast, threating local biodiversity (Pivello et al., 1999). Replacement by farmers of exotic grasses for native grass species in pastures could alleviate the pressure on the native biodiversity.

In conclusion, our data shows that seeds from twelve native grass species die after dry storage and can only be used during a short period after collection. On the other hand, viability of seeds from another sixteen species was not affected by dry 
193

194

195

196

197

198

199

200

201

202

203

204

205

206

207

208

209

210

211

212

213

214

215

216

leucostachyus, A. riparia, A. setifolia and E. inflexa have good potential to be explored for ornamental or forage usage as well as for recovering degraded areas.

\section{Acknowledgements}

We acknowledge CAPES, University of Brasília and Embrapa for the financial support to this study. José F. M. Valls was supported by a CNPq Scholarship during this study. We thank to Eduardo M. Barbosa and Augusto C. Franco for their helpful comments on the previous version of this paper. We confirm that there are no known conflicts of interest associated with this publication.

\section{References}

AIRES S.S., SATO M.N., MIRANDA H.S. (2014) Seed characterization and direct sowing of native grass species as a management tool. Grass and Forage Science, 69(3), $470-478$.

ALMEIDA S.P. (1995) Grupos fenológicos da comunidade de gramíneas perenes de um campo Cerrado no Distrito Federal. Pesquisa Agropecuária Brasileira, 30, 1067-1073. ALMEIDA S.P., SILVA J.C.S., RIBEIRO J.F., ZOBY J.L.F. (1987) Fenologia de espécies de gramíneas de área de pastagem nativa da região dos cerrados. Embrapa, relatório técnico anual, 70-71.

BASKIN C.C. and BASKIN J.M. (1998) Ecology of seed dormancy and germination in grasses. In: Cheplick GP. Population Biology of Grasses. Cambridge University Press. BASKIN C.C. and BASKIN J.M. (2014) Seeds: Ecology, Biogeography, and Evolution of Dormancy and Germination. 2nd. ed. Elsevier/Academic Press, San Diego, US FILGUEIRAS T.S., LONGHI-WAGNER H.M., VIANA P.L., ZANIN A., OLIVEIRA R.C., CANTO-DOROW T.S., SHIRASUNA R.T., OLIVEIRA R.P., RODRIGUES R.S., SANTOS-GONÇALVES A.P., WELKER C.A.D., FERREIRA F.M., 
A.C., VALLS J.F.M. Poaceae in Lista de Espécies da Flora do Brasil. Jardim Botânico do Rio de Janeiro. Disponível em: HOTHORN T., BRETZ F., WESTFALL P. (2008) Simultaneous Inference in General Parametric Models. Biometrical Journal, 50, 346-363. JEPSON W. (2005) A disappearing biome? Reconsidering land-cover change in the Brazilian savanna. The Geographical Journal, 171(2), 99-111.

KLINK C.A. and MACHADO R.B. (2005) Conservation of the Brazilian Cerrado. Conservation Biology, 19(3), 707-713.

LEITE G.G., NETO R.T., GOMES A.C., MORAES E.A., NETO C.R.B. (1997)

Dinâmica de perfilhos em gramíneas nativas dos Cerrados do Distrito Federal submetidas à queima. Revista Brasileira de Zootecnia, 26(4), 691-696. MOTT J.J. (1978) Dormancy and germination in five native grass species from savannah woodland communities of the northern territory. Australian Journal of Botany, 26, 621-631.

MUNHOZ C.B.R. and FELFILI J.M. (2007) Reproductive phenology of an herbaceoussubshrub layer of a Savannah (Campo Sujo) in the Cerrado Biosphere Reserve I, Brazil. Brazilian Journal of Biology, 67(2), 299-308. PIVELLO V.R., SHIDA C.N., MEIRELLES S.T. (1999) Alien grasses in Brazilian savannas: a threat to the biodiversity. Biodiversity and Conservation, 8, 1281-1294. R Core Team (2014) R: A language and environment for statistical computing. R Foundation for Statistical Computing, Vienna, Austria. URL http://www.R-project.org/. 
RAMOS D.M., DINIZ P., VALLS J.F.M. (2014) Habitat filtering and interspecific competition influence phenological diversity in an assemblage of Neotropical savanna grasses. Brazilian Journal of Botany, 37(1), 29-36.

SCOTT K., SAMANTHA S.S., DOUGLAS M.A.A. (2010) Soil seed banks confer resilience to savanna grass-layer plants during seasonal disturbance. Acta Oecologica, 36, 202-210.

SILESHI G.W. (2012) A critique of current trends in the statistical analysis of seed germination and viability data. Seed Science Research, 22, 145-159. SILVA J.F., ATAROFF M. (1985) Phenology, seed crop and germination of coexisting grass species from a tropical savanna in Western Venezuela. Acta Oecologica-

Oecologia Plantarum, 6(1), 41-51.

TANNUS J.L.S., ASSIS M.A., MORELLATO L.P.C. (2006) Fenologia reprodutiva em campo sujo e campo úmido numa área de cerrado no sudeste do Brasil, Itirapina-SP. Biota Neotropica, 6, 1-27. TESSEMA Z.K., DE BOER W.F., BAARS R.M.T., PRINS H.H.T. (2011) Seasonal patterns of germination and longevity in grass species in a semi-arid African savanna: Implications for restoration. In: TESSEMA Z.K. Recovery of rangelands: The

257 functioning of soil seed banks in a semi-arid African savanna. pp 87-104. PhD Thesis,

258 Wageningen University, Wageningen, The Netherlands. 
Table 1. Habitat of occurrence, time of seed dispersal and categorization of seed dormancy based on the results of germination and viability of fresh collected grass seeds from native species from open savannas and wet grasslands of Central Brazil.

\begin{tabular}{|c|c|c|c|c|c|c|c|}
\hline Species & $\begin{array}{c}\mathrm{G} \\
(\%)\end{array}$ & $\begin{array}{l}\mathrm{V} \\
(\%)\end{array}$ & $\begin{array}{l}\mathrm{GV} \\
(\%)\end{array}$ & Dormancy & $\begin{array}{c}\text { Seed } \\
\text { dispersal } \\
\text { (Month) }\end{array}$ & Habitat & Site \\
\hline Panicum olyroides Kunth & 0 & 98 & 0 & $\mathrm{D}$ & Jan & $\begin{array}{c}\text { Open } \\
\text { savanna }\end{array}$ & PNB \\
\hline $\begin{array}{l}\text { Paspalum carinatum } \\
\text { Humb. \& Bonpl. ex Flüggé }\end{array}$ & 0 & 65 & 0 & $\mathrm{D}$ & Feb & $\begin{array}{c}\text { Open } \\
\text { savanna }\end{array}$ & FAL \\
\hline $\begin{array}{l}\text { Echinolaena inflexa (Poir.) } \\
\text { Chase }\end{array}$ & 0 & 97 & 0 & $\mathrm{D}$ & Mar & $\begin{array}{c}\text { Open } \\
\text { savanna }\end{array}$ & FAL \\
\hline $\begin{array}{l}\text { Ichnanthus camporum } \\
\text { Swallen }\end{array}$ & 0 & 93 & 0 & $\mathrm{D}$ & Feb & $\begin{array}{c}\text { Open } \\
\text { savanna }\end{array}$ & FAL \\
\hline Eragrostis polytricha Nees & 0 & 67 & 0 & $\mathrm{D}$ & Dec & $\begin{array}{c}\text { Wet } \\
\text { grassland }\end{array}$ & PNB \\
\hline Aristida recurvata Kunth & 0 & 61 & 0 & $\mathrm{D}$ & Jun & $\begin{array}{c}\text { Open } \\
\text { savanna }\end{array}$ & PNB \\
\hline $\begin{array}{l}\text { Axonopus siccus var. } \\
\text { siccus (Nees) Kuhlm. }\end{array}$ & 1 & 76 & 1.31 & $\mathrm{D}$ & Feb & $\begin{array}{c}\text { Open } \\
\text { savanna }\end{array}$ & FAL \\
\hline $\begin{array}{l}\text { Paspalum glaucescens } \\
\text { Hack. }\end{array}$ & 2 & 68 & 2.94 & $\mathrm{D}$ & Feb & $\begin{array}{c}\text { Open } \\
\text { savanna }\end{array}$ & PNB \\
\hline $\begin{array}{l}\text { Paspalum maculosum } \\
\text { Trin. }\end{array}$ & 2 & 46 & 4.35 & $\mathrm{D}$ & Apr & $\begin{array}{l}\text { Wet } \\
\text { grassland }\end{array}$ & PNB \\
\hline $\begin{array}{l}\text { Agenium goyazense } \\
\text { (Hack.) Clayton }\end{array}$ & 4 & 64 & 6.25 & $\mathrm{D}$ & Jun & $\begin{array}{c}\text { Open } \\
\text { savanna }\end{array}$ & PNB \\
\hline $\begin{array}{l}\text { Sacciolepis myurus (Lam.) } \\
\text { Chase }\end{array}$ & 8 & 94 & 8.51 & $\mathrm{D}$ & Sep & $\begin{array}{l}\text { Wet } \\
\text { grassland }\end{array}$ & FAL \\
\hline Aristida riparia Trin. & 10 & 65 & 15.38 & $\mathrm{D}$ & Jun & $\begin{array}{c}\text { Open } \\
\text { savanna }\end{array}$ & FAL \\
\hline Aristida setifolia Kunth & 13 & 82 & 15.85 & $\mathrm{D}$ & Mar & $\begin{array}{c}\text { Open } \\
\text { savanna }\end{array}$ & FAL \\
\hline $\begin{array}{l}\text { Setaria parviflora (Poir.) } \\
\text { Kerguélen }\end{array}$ & 20 & 51 & 39.21 & $\mathrm{D}$ & Feb & $\begin{array}{c}\text { Open } \\
\text { savanna }\end{array}$ & PNB \\
\hline $\begin{array}{l}\text { Ctenium cirrhosum (Nees) } \\
\text { Kunth }\end{array}$ & 38 & 94 & 40.42 & $\mathrm{D}$ & Apr & $\begin{array}{c}\text { Open } \\
\text { savanna }\end{array}$ & PNB \\
\hline
\end{tabular}




\begin{tabular}{|c|c|c|c|c|c|c|c|}
\hline $\begin{array}{l}\text { Aristida gibbosa (Nees) } \\
\text { Kunth }\end{array}$ & 69 & 81 & 85.18 & ND & Jun & $\begin{array}{c}\text { Open } \\
\text { savanna }\end{array}$ & FAL \\
\hline Saccharum villosum Steud. & 89 & 92 & 96.74 & ND & Nov & $\begin{array}{c}\text { Wet } \\
\text { grassland }\end{array}$ & PNB \\
\hline Paspalum guttatum Trin. & 41 & 41 & 100 & ND & Dec & $\begin{array}{c}\text { Open } \\
\text { savanna }\end{array}$ & PNB \\
\hline $\begin{array}{l}\text { Paspalum polyphyllum } \\
\text { Nees }\end{array}$ & 52 & 52 & 100 & ND & Aug & $\begin{array}{c}\text { Wet } \\
\text { grassland }\end{array}$ & FAL \\
\hline $\begin{array}{l}\text { Paspalum erianthum Nees } \\
\text { ex. Trin. }\end{array}$ & 52 & 52 & 100 & ND & Dec & $\begin{array}{c}\text { Open } \\
\text { savanna }\end{array}$ & PNB \\
\hline $\begin{array}{l}\text { Paspalum pectinatum Nees } \\
\text { ex Trin. }\end{array}$ & 54 & 54 & 100 & ND & Jan & $\begin{array}{c}\text { Open } \\
\text { savanna }\end{array}$ & PNB \\
\hline $\begin{array}{l}\text { Homolepis longispicula } \\
\text { (Döll) Chase }\end{array}$ & 57 & 57 & 100 & ND & Dec & $\begin{array}{c}\text { Wet } \\
\text { grassland }\end{array}$ & PNB \\
\hline $\begin{array}{l}\text { Mesosetum ferrugineum } \\
\text { (Trin.) Chase }\end{array}$ & 68 & 68 & 100 & ND & Jan & $\begin{array}{c}\text { Wet } \\
\text { grassland }\end{array}$ & PNB \\
\hline $\begin{array}{l}\text { Andropogon leucostachyus } \\
\text { Kunth }\end{array}$ & 79 & 79 & 100 & ND & Oct & $\begin{array}{l}\text { Wet } \\
\text { grassland }\end{array}$ & FAL \\
\hline $\begin{array}{l}\text { Anthaenantia lanata } \\
\text { (Kunth) Benth. }\end{array}$ & 81 & 81 & 100 & ND & Jan & $\begin{array}{c}\text { Open } \\
\text { savanna }\end{array}$ & PNB \\
\hline $\begin{array}{l}\text { Schizachyrium } \\
\text { sanguineum (Retz.) Alston }\end{array}$ & 92 & 92 & 100 & ND & Jun & $\begin{array}{c}\text { Open } \\
\text { savanna }\end{array}$ & PNB \\
\hline Arthropogon villosus Nees & 97 & 97 & 100 & ND & Dec & $\begin{array}{c}\text { Wet } \\
\text { grassland }\end{array}$ & PNB \\
\hline $\begin{array}{l}\text { Elionurus muticus } \\
\text { (Spreng.) Kuntze }\end{array}$ & 99 & 99 & 100 & ND & Dec & $\begin{array}{c}\text { Open } \\
\text { savanna }\end{array}$ & PNB \\
\hline
\end{tabular}

Site of occurrence: PNB (National Park of Brasília) and FAL (Água Limpa farm). G = Germination; $\mathrm{V}=$ Viability; $\mathrm{GV}=$ Germination proportion of viable seeds. $\mathrm{D}=$ Dormant; $\mathrm{ND}=$ Non-dormant. 


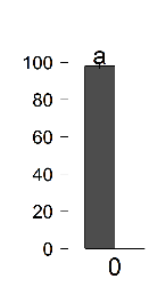

Panicum olyroides

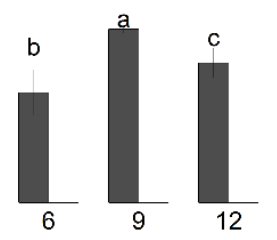

Paspalum carinatum
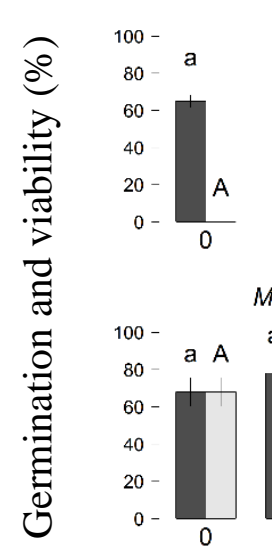

a

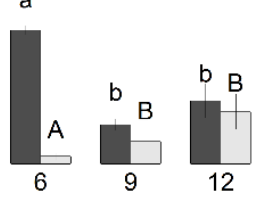

Mesosetum ferrugineum
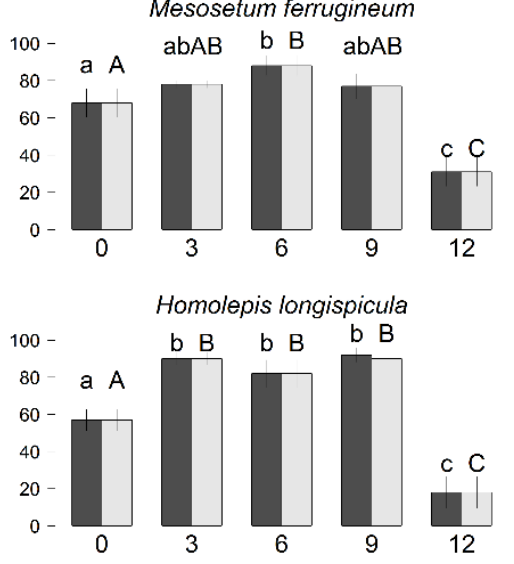

Paspalum glaucecens
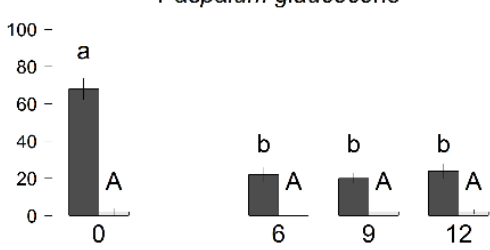

Elionurus muticus

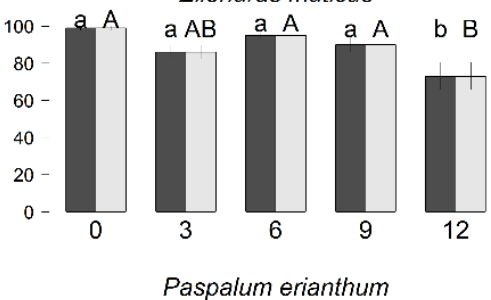

$100-$
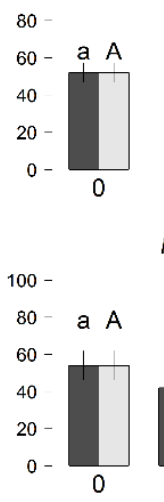

Paspalum erianthum

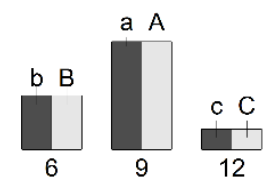

Paspalum pectinatum

$A$ a $A$ a $A$

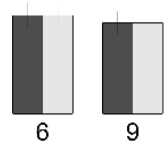

b B

$\overline{12}$

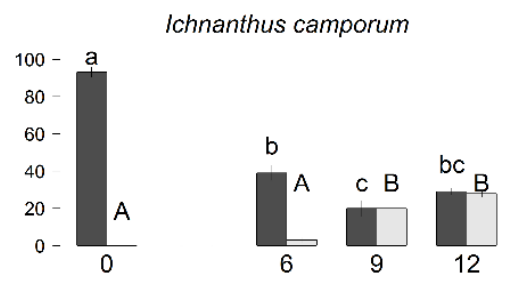

Arthropogon villosus

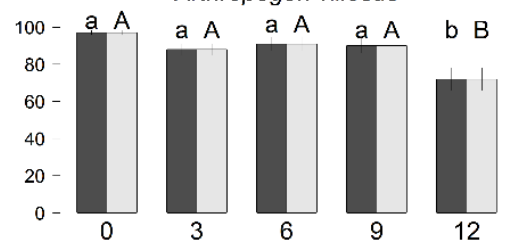

Paspalum guttatum

$100-$

80 -

60 - a A a A a A
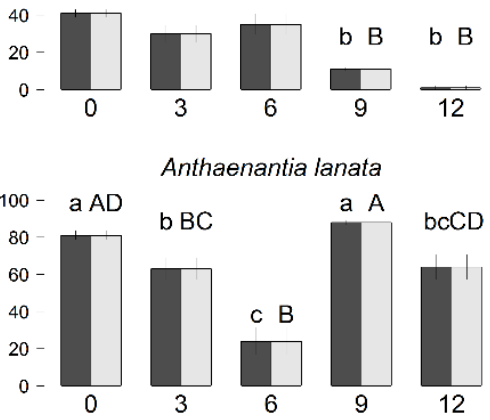

Figure 1. Germination and viability of grass seeds negatively affected by dry storage in species from open savannas and wet grasslands of Central Brazil. Capital letters refers to post-hock test on germination; Lower case letter refers to post-hock test on viability. Dark grey bars = seed viability; Light grey bars $=$ seed germination. Average $\pm 95 \%$ CI. 

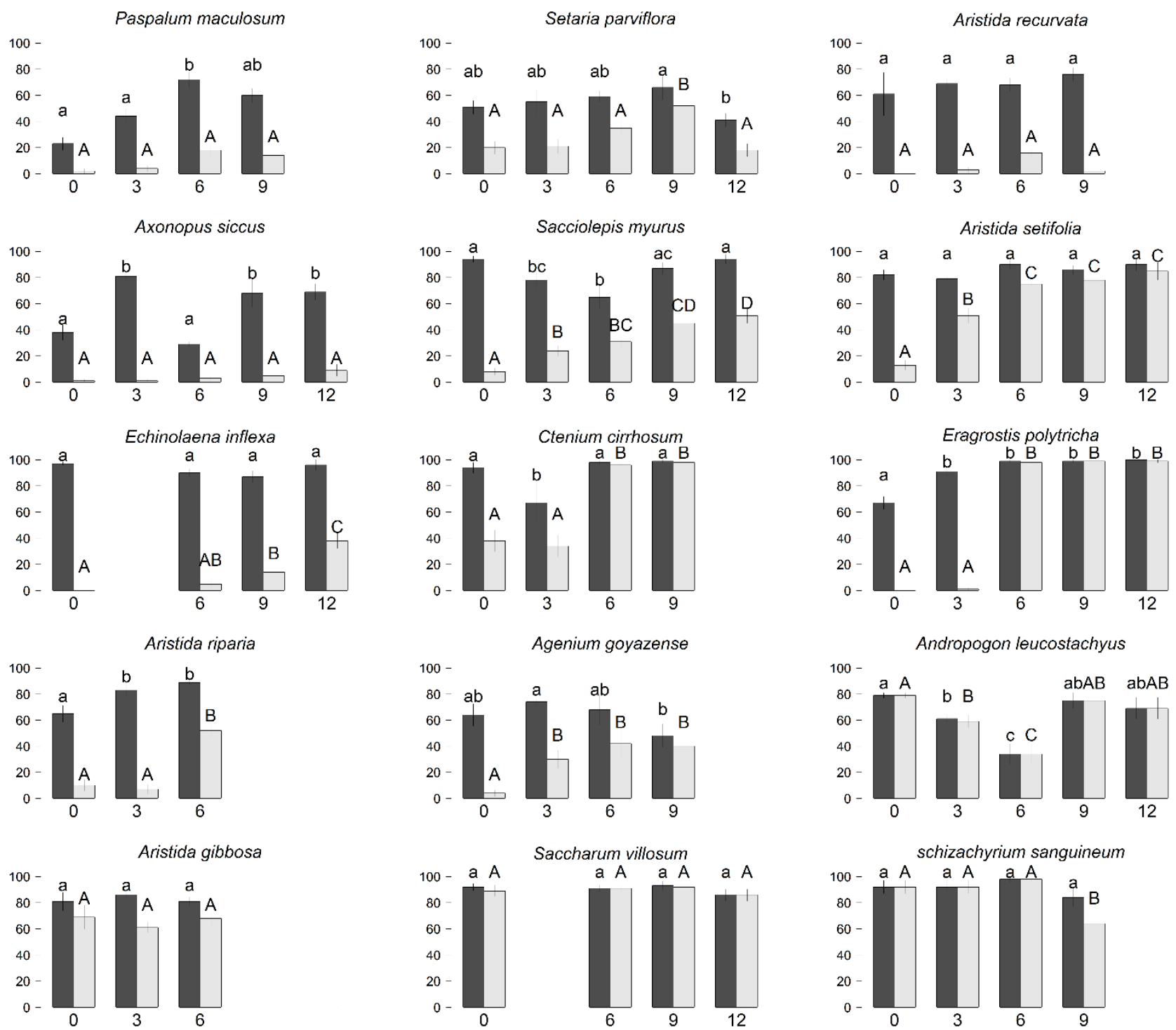

Agenium goyazense

Andropogon leucostachyus
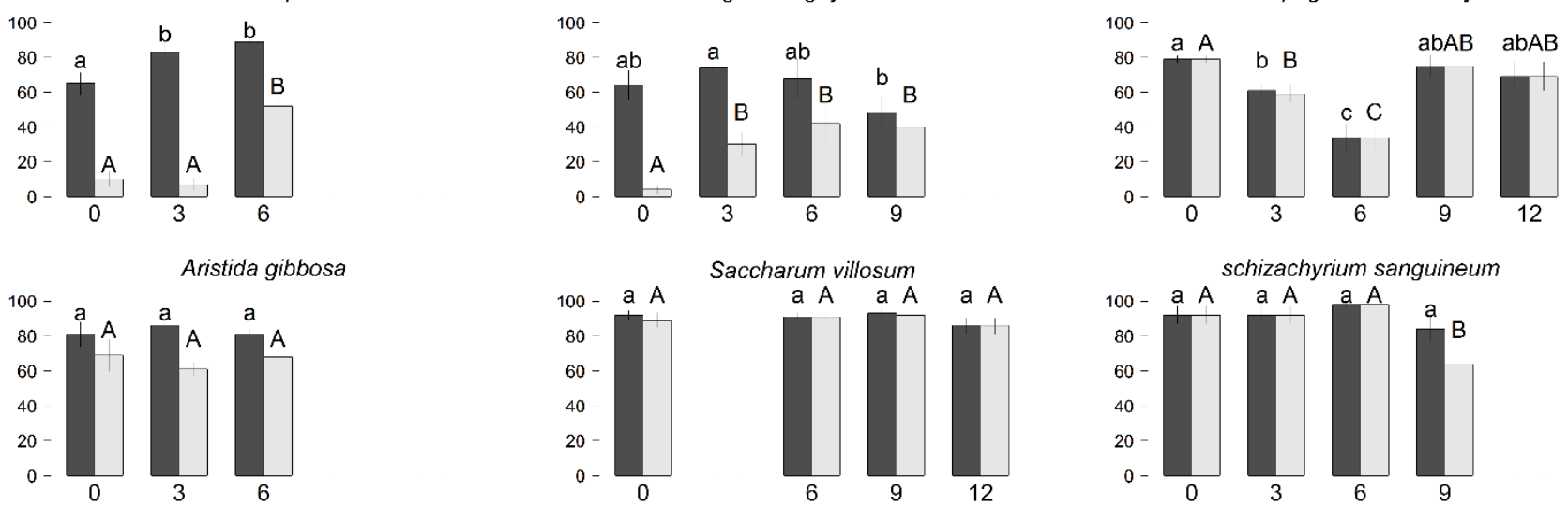

Saccharum villosum

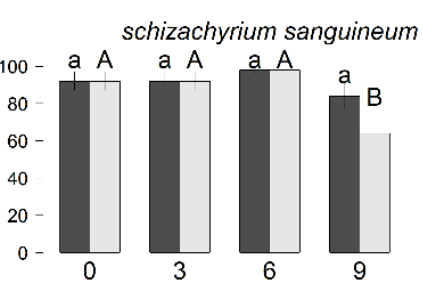

Paspalum polyphyllum

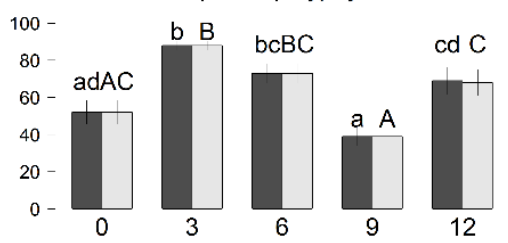

Figure 2. Germination and viability of grass seeds not affected by dry storage in species from open savannas and wet grasslands of Central Brazil. Capital letters refers to post-hock test on germination; Lower case letter refers to post-hock test on viability. Dark grey bars = seed viability; Light grey bars = seed germination. Average \pm 95\% CI. 
O comportamento da germinação ao longo do armazenamento diferiu entre os

272 campos sujos e os campos úmidos. Em ambos os campos a germinação aumentou com o

273 armazenamento, porém nos campos úmidos esse aumento aconteceu mais rápido, após

274 três meses, do que no campo sujo, após seis meses. Em relação à viabilidade, no campo sujo as sementes morreram após doze meses, enquanto que no campo úmido permaneceram vivas e com alta germinação. Estes resultados indicam que a dormência faz com que a germinação nos campos sujos ocorra no máximo na estação chuvosa seguinte após a dispersão das sementes. Por outro lado, nos campos úmidos, aonde a sazonalidade é menos marcante, a germinação pode ocorrer até mesmo nos meses de seca.

A germinação das sementes de gramíneas foi influenciada pela época de dispersão. Sementes dispersas no final da estação chuvosa tiveram maior dormência do que sementes dispersas no início da estação chuvosa e na estação seca. Após três meses de armazenamento, a germinação de sementes dispersas no final da estação chuvosa aumentou, não havendo mais diferenças entre os períodos de dispersão. Sementes dispersas no início da estação chuvosa tem toda a estação chuvosa para que ocorra a germinação e o estabelecimento das plântulas ( 7 meses). Por outro lado, a germinação no final da chuva é arriscada pois, estas sementes teriam apenas 3 meses de estação chuvosa pela frente. $\mathrm{O}$ alto nível de dormência nestas sementes consiste em uma síndrome de evitar a seca, previamente registrada para espécies de ambientes sazonais (Mott 1978; Veenendaal et al. 1996; O'Connor \& Everson 1998; McIvor \& Howden 2000; Scott et al. 2010). Já a perda da dormência indica que ocorre uma sincronização da germinação com a estação chuvosa seguinte. A ausência de dormência nas sementes de espécies dispersas na seca pode ser uma estratégia vantajosa uma vez que a estação chuvosa se aproxima. 
A estratégia de dispersão teve influência nos padrões de germinação. Sementes

295 frescas de espécies com dispersão barocórica germinaram menos, ouseja foram mais

296 dormentes, do que sementes de espécies com dispersão anemocóricas. A densidade de

297 competidores coespecíficos durante o crescimento das plântulas afeta negativamente o

298 sucesso reprodutivo (Orrock \& Christopher 2010). Por dispersar longe e não terem

299 dormência as sementes anemocóricas podem cair em sítios mais abertos e se beneficiar

300 de uma estação de crescimento com menos competidores por recursos. Por outro lado, a

301 dispersão em sementes barocóricas é limitada, causando um adensamento de sementes

302 próximo à planta-mãe. Como estas espécies dispersam durante a estação chuvosa, há

303 umidade suficiente para que a germinação ocorra, aumentando a competição entre

304 plântulas coespecíficas e com a planta-mãe. Entretanto, a dormência diminui esta pressão

305 competitiva, aumentando a chance de ocorrer uma dispersão secundária e,

306 consequentemente, espalhando a germinação no tempo e no espaço. 